\title{
ANÁLISE DAS TENDÊNCIAS DA CHUVA E DAS TEMPERATURAS EXTREMAS NA REGIÃO DE BELÉM (PA)
}

\section{ADRIRÓSEO RAIMUNDO ALVES DOS SANTOS METEOROLOGISTA E ENGENHEIRO AGRÔNOMO}

Orientador: Antonio Roberto Pereira
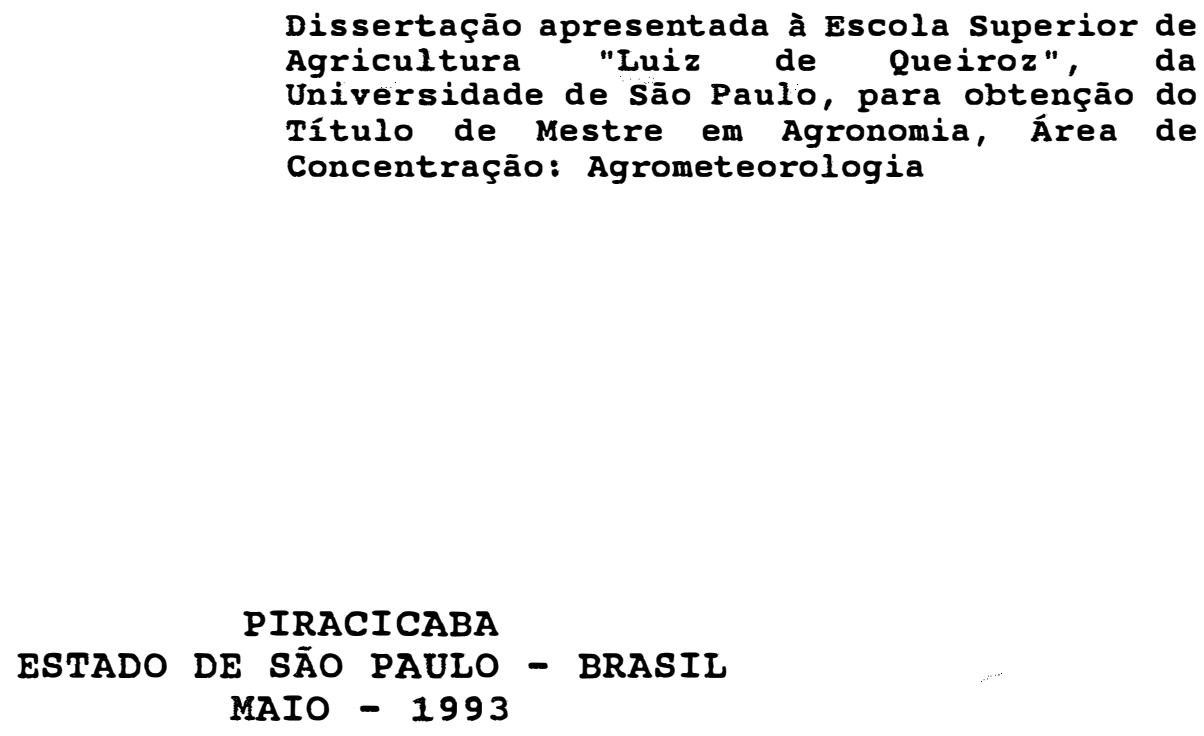
Ficha catalográfica preparada pela Seçăo de Livros da Divisáo de Biblioteca e Documentaçáo - FCLQ/USF

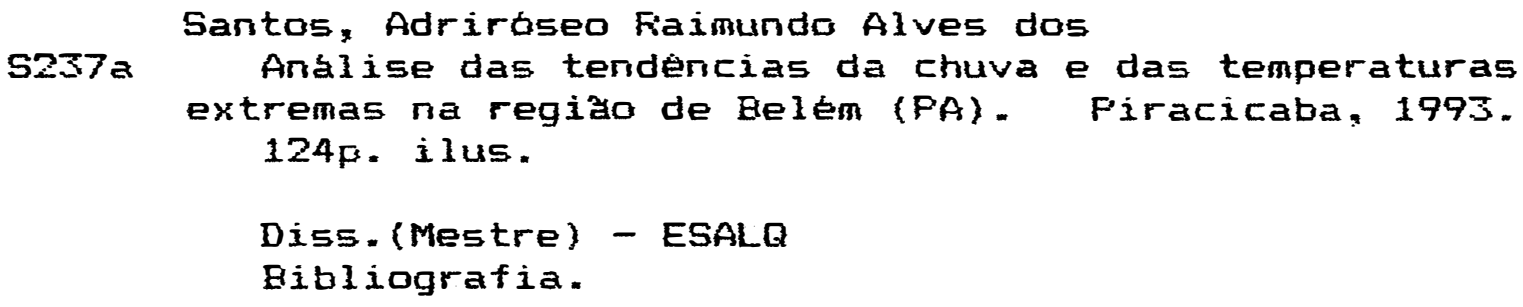

1. Chuva - Distribuiçăo - Eelém, FA 2. Metearalogia - Analise - Helem, PA 3. Temperatura - Fegistro Belen, FA I. Escola Superior de Agricultura Luiz de Queiroz, Firacicaba 


\section{ANÁLISE DAS TENDÊNCIAS DA CHUVA E DAS TEMPERATURAS EXTREMAS NA REGIÃO DE BELÉM (PA)}

\section{ADRIRÓSEO RAIMUNDO ALVES DOS SANTOS}

Aprovado em: 28 de maio de 1993

COMISSÃO JULGADORA:

Prof. Dr. Antonio Roberto Pereira ESALQ/USP

Prof. Dr. Nilson Augusto Villa Nova ESALQ/USP

Prof. Dr. José Marques DCM/UERJ

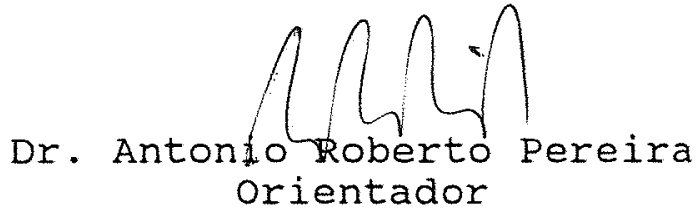


Aos meus pais, Adrião e Rosa, e a memória de meu Tio Antonio, que com muita dedicação sempre manifestaram apoio e incentivo.

A MINHA GRATIDÃO

$\grave{A}$ esposa, Cristina, que ao meu lado repartiu comigo todos os sentimentos de alegria, angústia, decepções, vitórias e derrotas que deram sabor de vitória.

DEDICO

Aos meus filhos, Adriene, Adriano

e Andrey, que são a razão de todos os esforços. 


\section{AGRADECIMENTOS}

A Deus, pela fé, perseverança, saúde e por todas as graças concedidas durante o curso;

Ao Prof. Dr. Antonio Roberto Pereira, pela orientação e pelo total apoio e confiança depositada em meu trabalho;

Ao Prof. Dr. Nilson Augusto Villa Nova, pela disposição nos ensinamentos e pela feliz amizade;

Ao Prof. Dimetrie Nechet, pela colaboração, atenção e amizade;

Ao Instituto Nacional de Meteorologia - INMET, por ter me proporcionado a oportunidade de realizar este curso;

A Coordenação de Aperfeiçoamento de Pessoal de Nível Superior (CAPES), pelo apoio financeiro;

Ao Departamento de Física e Meteorologia da ESALQ e a todos os seus funcionários, pela colaboração e apoio concedido;

A Maria Inês Moreira de Araujo, Luiz Renato Lazinski, Claudio Lazzarotto, Sérgio Dal Fabbro, Manoel Henrique Gamero Guandique, Paulo cesar Sentelhas, Vagner Camarini Alvez, Roberto Fernando Rosa Cruz e Guilherme Pereira Alvez, pelo convívio e amizade;

Ao funcionário do CIAGRI João carlos pela colaboração desinteressada; 
Ao Engo Agro oscar Vieira pela colaboração e amizade;

Ao desenhista Raimundo Lira Castro Neto pela colaboração e amizadade;

Em especial, agradeço ao padrinho carlos Alberto de Aragão Vinagre e familia, ao compadre José Carlos Peruca e família, ao primo Grimário Carvalho viana e família e ao tio Aniceto Alves de Carvalho e familia;

A todos que, de uma forma ou de outra, contribuíram para a realização deste trabalho. 
INDICE

Página

INDICE DE FIGURAS........................

INDICE DE TABELAS..........................

RESUMO....................................

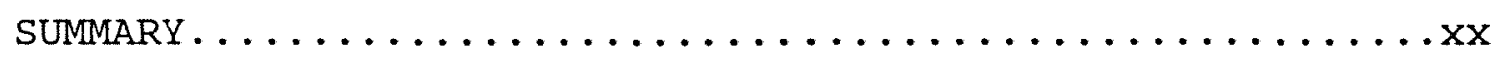

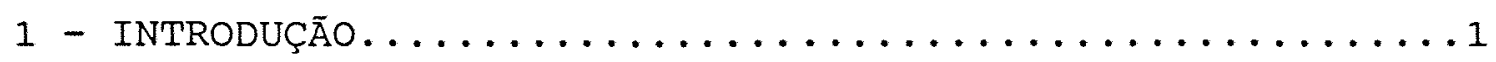

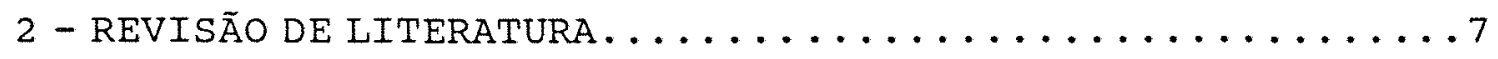

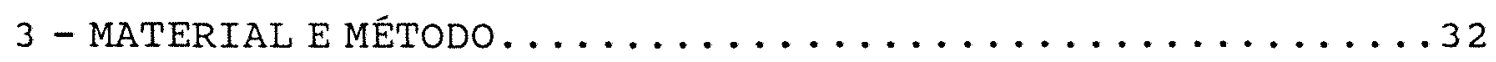

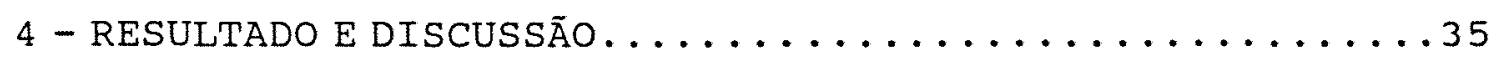

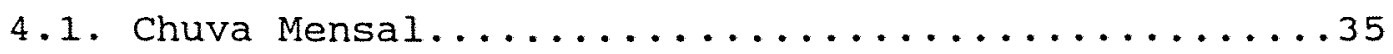

4.2. Chuva Diária...........................

4.3. Tendência secular....................62

4.3.1. Tendência Anual das Chuvas e Temperaturas Extremas....................64

4.3.2. Tendência Mensal das Chuvas..........64

4.3.3. Tendência Mensal da Temperatura Máxima Absoluta......................66

4.3.4. Tendência Mensal da Temperatura Mínima Absoluta........................

4.4. Efeito do ENos sobre as Chuvas............. 83

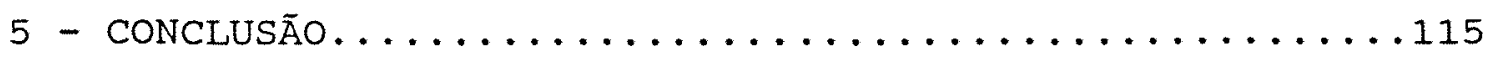

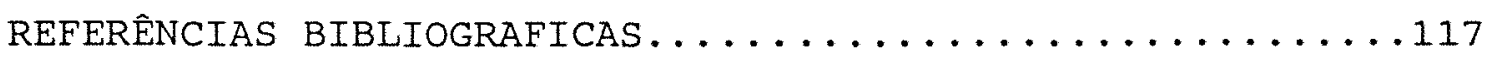




\section{ÍNDICE DE FIGURAS}

Página

Figura 1 - Localização de Belém em relação ao espaço

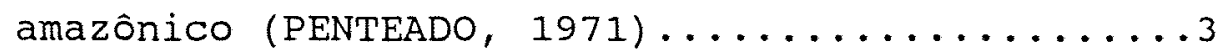

Figura 2 - Localização do sítio urbano da cidade de Belém (PENTEAdo, 1971).................

Figura 3 - Áreas do Globo que apresentam anormalidades periódicas, em consequência do ENOS

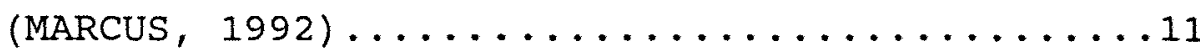

Figura 4 - Valores do campo vetorial $\vec{Q}=\overrightarrow{Q_{\lambda}}+\vec{Q}_{\phi}$. Média do período 1972/1975, obtida para as quadriculas de $5^{\circ}$ de latitude por $5^{\circ}$ de longitude. Valores para março. Linhas tracejadas: água precipitável, em mm. 1 $\mathrm{cm}=2000 \mathrm{gv} / \mathrm{cm} . \mathrm{s}$ (MARQUES et alii, 1979)....25

Figura 5 - Valores do campo vetorial $\vec{Q}=\overrightarrow{Q_{\lambda}}+\overrightarrow{Q_{\phi}}$. Média do período 1972/1975, obtida para as quadriculas de $5^{\circ}$ de latitude por $5^{\circ}$ de longitude. Valores para junho. Linhas tracejadas: água precipitável, em mm. 1 $\mathrm{cm}=2000 \mathrm{gv} / \mathrm{cm} . \mathrm{s}($ MARQUES et alii, 1979) ....25 
Figura 6 - Valores do campo vetorial $\vec{Q}=\overrightarrow{Q_{\lambda}}+\vec{Q}_{\phi}$. Média do período 1972/1975, obtida para as quadriculas de $5^{\circ}$ de latitude por $5^{\circ}$ de longitude. Valores para setembro. Linhas tracejadas: água precipitável, em $\mathrm{mm} \cdot 1$ $\mathrm{cm}=2000 \mathrm{gv} / \mathrm{cm} . \mathrm{s}($ MARQUES et alii, 1979) ...26

Figura 7 - Valores do campo vetorial $\vec{Q}=\overrightarrow{Q_{\lambda}}+\overrightarrow{Q_{\phi}}$. Média do período 1972/1975, obtida para as quadriculas de $5^{\circ}$ de latitude por $5^{\circ}$ de longitude. Valores para dezembro. Linhas tracejadas: água precipitável, em mm. 1 $\mathrm{cm}=2000 \mathrm{gv} / \mathrm{cm} . \mathrm{s}($ MARQUES et alii, 1979) ...26

Figura 8 - Gráficos demonstrativos............... 37

Figura 9 - Gráficos demonstrativos...............38

Figura 10 - Distribuição de frequência da intensidade de chuva no período 1967 a 1991 dos meses janeiro e fevereiro, sendo representada a frequência de dias sem chuva (classe 0 ). Fonte de dados brutos: INMET. . . 44 
Figura 11 - Distribuição de frequência da intensidade de chuva no período 1967 a 1991 dos meses março e abril, sendo representada a frequência de dias sem chuva (classe 0). Fonte de dados brutos: INMET.........43

Figura 12 - Distribuição de frequência da intensidade de chuva no período 1967 a 1991 dos meses maio e junho, sendo representada a frequência de dias sem chuva (classe 0). Fonte de dados brutos: INMET...........44

Figura 13 - Distribuição de frequência da intensidade de chuva no período 1967 a 1991 dos meses julho e agosto, sendo representada a frequência de dias sem chuva (classe 0). Fonte de dados brutos: InMET.........45

Figura 14 - Distribuição de frequência da intensidade de chuva no período 1967 a 1991 dos meses setembro e outubro, sendo representada a frequência de dias sem chuva (classe 0). Fonte de dados brutos:

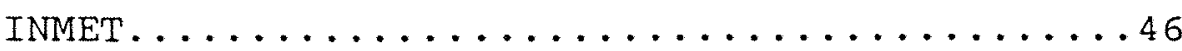


Figura 15 - Distribuição de frequência da intensidade de chuva no período 1967 a 1991 dos meses novembro e dezembro, sendo representada a frequência de dias sem chuva (classe 0). Fonte de dados brutos: INMET .

Figura 16 - Distribuição percentual da intensidade de chuva em Belém...................48

Figura 17 - Variabilidade diurna de chuva e trovoadas no mês de janeiro em Belém - PA.

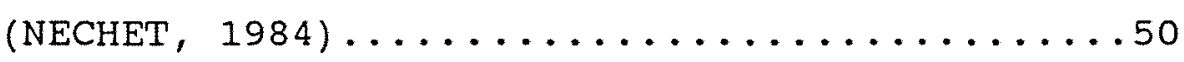

Figura 18 - Variabilidade diurna de chuva e trovoadas no mês de fevereiro em Belém - PA.

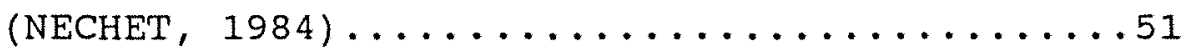

Figura 19 - Variabilidade diurna de chuva e trovoadas no mês de março em Belém - PA.

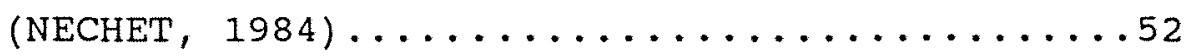

Figura 20 - Variabilidade diurna de chuva e trovoadas no mês de abril em Belém - PA.

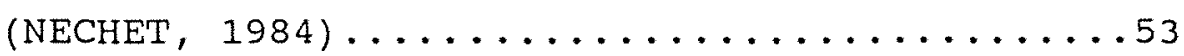


Figura 21 - Variabilidade diurna de chuva e trovoadas no mês de maio em Belém - PA.

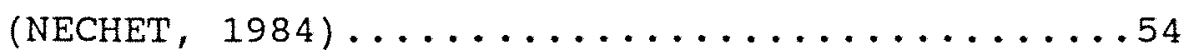

Figura 22 - Variabilidade diurna de chuva e trovoadas no mês de junho em Belém - PA. $($ NECHET, 1984$) \ldots \ldots \ldots \ldots \ldots \ldots \ldots \ldots \ldots \ldots \ldots \ldots \ldots \ldots \ldots \ldots \ldots \ldots \ldots$

Figura 23 - Variabilidade diurna de chuva e trovoadas no mês de julho em Belém - PA.

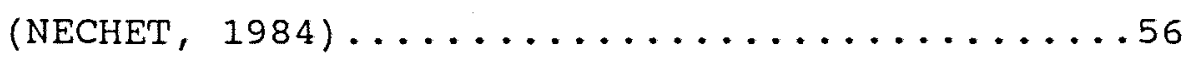

Figura 24 - Variabilidade diurna de chuva e trovoadas no mês de agosto em Belém - PA. (NECHET, 1984) .................... 57

Figura 25 - Variabilidade diurna de chuva e trovoadas no mês de setembro em Belém - PA. (NECHET, 1984$) \ldots \ldots \ldots \ldots \ldots \ldots \ldots \ldots \ldots \ldots \ldots \ldots \ldots \ldots \ldots \ldots \ldots \ldots \ldots$

Figura 26 - Variabilidade diurna de chuva e trovoadas no mês de outubro em Belém - PA.

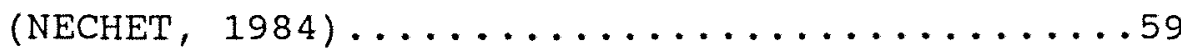


Figura 27 - Variabilidade diurna de chuva e trovoadas no mês de novembro em Belém - PA. (NECHET, 1984) .60

Figura 28 - Variabilidade diurna de chuva e trovoadas no mês de dezembro em Belém - PA.

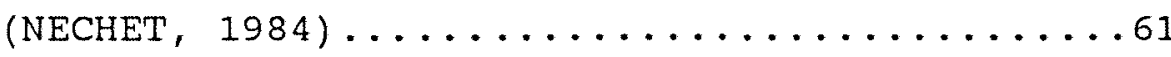

Figura 29 - Variação do total anual de chuva (a), variação da temperatura máxima absoluta do ano (b), variação da temperetcia mínima absoluta do ano (c); periodos: $(1896-1991),(1896-1930), \quad(1931-$ 1960), (1961-1991). Fonte dos dados brutos: INMET....................

Figura 30 - Variação do total de chuva do mês de janeiro (a), variação da temperatura máxima absoluta no mês de janeiro (b), variação da temperatura mínima absoluta no mês de janeiro (c), períodos: (1896-1991), (1896-1930), $(1931-1960),(1961-1991)$. Fonte dos dados brutos: INMET................ 
Figura 31 - Variação do total de chuva do mês de fevereiro (a), variação da temperatura máxima absoluta no mês de fevereiro (b), variação da temperatura mínima absoluta no mês de fevereiro (c), períodos: $(1896-1991),(1896-1930)$, $(1931-1960),(1961-1991)$. Fonte dos dados brutos: INMET. . . . . . . . . . .

Figura 32 - Variação do total de chuva do mês de março (a), variação da temperatura máxima absoluta no mês de março (b), variação da temperatura mínima absoluta no mês de março (c) períodos: (1896 $-1991),(1896-1930),(1931-1960)$, (1961 - 1991). Fonte dos dados brutos: INMET $\ldots \ldots \ldots \ldots \ldots \ldots \ldots \ldots \ldots \ldots \ldots \ldots \ldots$

Figura 33 - Variação do total de chuva do mês de abril (a), variação da temperatura máxima absoluta no mês de abril (b), variação da temperatura mínima absoluta no mês de abril (c) períodos: (1896 - 1991), (1896-1930), (1931-1960), $(1961$ - 1991). Fonte dos dados brutos: INMET . . . . . . . . . . . . . . . . 74 
Figura 34 - Variação do total de chuva do mês de maio (a), variação da temperatura máxima absoluta no mês de maio (b), variação da temperatura mínima absoluta no mês de maio (c), períodos: $(1896-1991),(1896-1930), \quad(1931-$ 1960), (1961 - 1991). Fonte dos dados brutos: INMET....................

Figura 35 - Variação do total de chuva to vè de junho (a), variação da tenperatura máxima absoluta no mês de junho (b), variação da temperatura mínima absoluta no mês de junho (c), períodos: $(1896-1991),(1896-1930), \quad(1931-$ 1960), (1961 - 1991). Fonte dos dados brutos: INMET...................

Figura 36 - Variação do total de chuva do mês de julho (a), variação da temperatura máxima absoluta no mês de julho (b), variação da temperatura mínima absoluta no mês de julho (c), periodos: $(1896-1991),(1896-1930), \quad(1931-$ 1960), (1961 - 1991). Fonte dos dados brutos: INMET................... 
Figura 37 - Variação do total de chuva do mês de agosto (a), variação da temperatura máxima absoluta no mês de agosto (b), variação da temperatura mínima absoluta no mês de agosto (c), periodos: $(1896-1991),(1896-1930)$, $(1931-1960),(1961-1991)$. Fonte dos dados brutos: INMET. .............78

Figura 38 - Variação do total de chuva do mês de setembro (a), variação da temperatura máxima absoluta no mês de setembro (b), variação da temperatura mínima absoluta no mês de setembro (c), períodos: $(1896-1991),(1896-1930)$, $(1931-1960),(1961-1991)$. Fonte dos dados brutos: INMET..................

Figura 39 - Variação do total de chuva do mês de outubro (a), variação da temperatura máxima absoluta no mês de outubro (b), variação da temperatura mínima absoluta no mês de outubro (c), periodos: (1896-1991), (1896-1930), $(1931-1960),(1961-1991)$. Fonte dos dados brutos: INMET.................. 
Figura 40 - Variação do total de chuva do mês de novembro (a), variação da temperatura máxima absoluta no mês de novembro (b), variação da temperatura mínima absoluta no mês de novembro (c), períodos: $(1896-1991),(1896-1930)$, $(1931-1960),(1961-1991)$. Fonte dos dados brutos: INMET...............81

Figura 41 - Variação do total de chuva do mês de dezembro (a), variação da temperatura máxima absoluta no mês de dezembro (b), variação da temperatura mínima absoluta no mês de dezembro (c), periodos: $(1896-1991),(1896-1930)$, $(1931-1960),(1961-1991)$. Fonte dos dados brutos: INMET...................

Figura 42 - Correlação entre ATPS (Niño 1+2) e ICB. período: (1987 - 1991). Fonte de dados:
1) ATPS (Niño 1+2) - CLIMANÁLISE
2) ICB - INMET $\ldots \ldots \ldots \ldots \ldots \ldots \ldots$ 
xvi

Página

$$
\begin{aligned}
& \text { Figura } 43 \text { - Variação entre ATPS (Niño 1+2) e ICB, } \\
& \text { período: (1987 - 1991). Fontes de dados: } \\
& \text { 1) ATPS (Niño 1+2) - CLIMANÁLISE } \\
& \text { 2) ICB }- \text { INMET } \ldots \ldots \ldots \ldots \ldots \ldots \ldots \ldots \ldots \ldots \ldots
\end{aligned}
$$


xvii

\section{INDICE DE TABELAS}

\section{Página}

Tabela 1 - Registro mensal de chuva $(\mathrm{mm}) \ldots \ldots \ldots \ldots \ldots$

Tabela 2 - Valores de frequência de classe da chuva ocorrida no período: $1967-1991 \ldots \ldots \ldots \ldots \ldots$

Tabela 3 - Valores percentuais das classes de chuva ocorrente no período: 1967-1991..........40

Tabela 4 - Valores quantitativos de tendências de chuva em mm...................62

Tabela 5 - Valores quantitativos de tendências da temperatura máxima absoluta em ${ }^{\circ} \mathrm{C} \ldots \ldots \ldots 63$

Tabela 6 - Valores quantitativos de tendências da temperatura mínima absoluta em ${ }^{\circ} \mathrm{C} \ldots \ldots \ldots 63$

Tabela 7 - Correlação entre ATPS e ICB (1987 a 1991) . . .883 
xviii

\title{
ANÁLISE DAS TENDÊNCIAS DA CHUVA \\ E DAS TEMPERATURAS EXTREMAS \\ NA REGIÃO DE BELÉM (PA)
}

\author{
Autor: Adriróseo Raimundo Alves dos Santos \\ Orientador: Prof. Dr. Antonio Roberto Pereira
}

RESUMO

A cidade de Belém, situa-se numa das áreas mais chuvosas do Brasil, com indices anuais superiores a $2000 \mathrm{~mm}$, e notabiliza-se pela sua isotermia, apresentando amplitude térmica anual em torno de $1,0^{\circ} \mathrm{C}$ a $3,0^{\circ} \mathrm{C}$. Possui dois períodos distintos: o chuvoso (dezembro a maio) e o menos chuvoso (junho a novembro). No entanto, o regime de chuvas varia de ano para ano.

Foi proposto estudar detalhadamente a série de dados meteorológicos de Belém desde 1896 até 1991 (registros mensais) e de 1967 até 1991 (registros diários), com intuito de entender a dinâmica das variações não só entre anos, mas também para verificar se existe uma tendência nos registros climáticos da região. Uma análise será feita com os valores extremos de temperatura, visto que os valores médios suavizam as tendências e flutuações. A distribuição das chuvas a nível diário também foi estudada detalhadamente. 
xix

Para correlacionar a chuva mensal de Belém com as anomalias de temperatura da superficie do mar do Pacifico Sul (ATPS), utilizou-se indices de anomalia de temperatura da região do Niño $1+2$, no período de janeiro de 1987 a dezembro de 1991. A intensidade de chuva diária e a frequência de dias sem chuva foi calculada através da distribuição de frequência relativa. As tendências temporais das temperaturas absolutas extremas e dos totais mensais de chuvas foram calculados através da regressão linear.

os resultados obtidos indicam uma tendência

crescente no total de chuva anual, uma tendencia ligeiramente decrescente na temperatura máxima absoluta e uma ligeira tendência crescente na temperatura mínima absoluta. O quadrimestre mais chuvoso em Belém, janeiro a abril, recebe pouca influência das ATPS na quantidade de chuva, sendo também, significante as variações de temperatura de superfície do mar no oceano Atlântico. 


\title{
ANALYSIS OF THE TENDENCIES OF
}

\section{RAINFALL AND EXTREMES TEMPERATURES}

\section{IN BELÉM, PA, BRAZIL}

\author{
Author: Adriróseo Raimundo Alves dos Santos \\ Adviser: Prof. Dr. Antonio Roberto Pereira
}

SUMMARY

On the average Belém, $P A$, has in annual rainfall above $2000 \mathrm{~mm}$. Being located near the equator its air temperature has an annual amplitude between $1^{\circ} \mathrm{C}$ and $3^{\circ} \mathrm{C}$. Basically, there are only two seasons being one, from december to may, with most of the rains, and another, from june to november, with much less rainfall.

In order to study the climatic tendencies of the region the series of monthly rainfall and extreme (maximum and minimum) temperatures measured since 1896 were analysed. Results from linear regression analysis indicate an overall tendency of increasing both the annual rainfall and the absolute minimum temperature, white the absolute maximum temperature showed a smell decrease.

Daily meteorological data for the period 19671991 was also analysed in order to understand the dynamics of the rainfall in the region. The rainfall deviations from 
$x \times i$

the climatological normal was associated with the El Niño Southern Oscilation Index fot the Niño $1+2$ area. It was found that ENSO had little effect upon the january-march rainfall because the Intertropical Convergence Zone dictates the dynamics of the weather in that period. 


\section{1 - INTRODUÇĀo}

A cidade de Belém, capital do Estado do Pará, situada a pouco mais de 1 grau de latitude sul', junto à foz do rio Pará, às margens de um braço secundário, localmente conhecido como baia de Guajará, encontrando-se a cerca de 120 quilômetros do mar.

Naturalmente abrigada do oceano e ao mesmo tempo, distante do atual estuário amazônico constituído pelo Canal do Norte, onde é conhecida a violência das águas do maior rio em volume d'água do mundo, o que ocasionou a fragmentação de várias ilhas ali existentes, como Caviana e Mexiana, além da presença das "Pororocas" e dos fortes ventos de Nordeste.

Em relação ao grande espaço amazônico do qual é a sua capital, Belém ocupa uma notável posição muito bem marcada pela sua excentricidade, sua posiçāo geografica muito ao contrário de the servir como fator negativo de desenvolvimento, constitui exatamente o fator primeiro de seu progresso, pois que domina a entrada do grande vale, o

1 Os dados oficiais dão para Belém as seguintes coordenadas: $1^{\circ} 27^{\prime}$ de latitude sul, $48^{\circ} 27^{\prime}$ de longitude Oeste de Greenwich e altitude acima do nível do mar de 24 metros. 
que the assegura o controle de um vasto território como talvez nenhuma outra cidade brasileira conheça (Figura 1). Dentro de uma paisagem natural dominada pela presença da mata amazônica, está edificada a cidade de Belém, tendo por sitio parte do espaço localizado entre a baia do Guajará e o rio Guamá (Figura 2).

Do ponto de vista climático, Belém possui marcante originalidade dentro da Amazônia. Situada numa latitude equatorial, com poucos metros de altitude, a cidade deveria ser atingida pelas condições climáticas comuns à região em que se encontra; isto, entretanto, não se dá, em virtude de não haver estação seca definida e de ser uma das cidades mais bem ventiladas da Amazônia Brasileira.

No que se refere às temperaturas, Belém se notabiliza pela sua isotermia, apresentando amplitude térmica anual em torno de $1^{\circ} \mathrm{C}$ a $3^{\circ} \mathrm{C}$, em consequência dos raios solares atingirem-na quase que verticalmente, na passagem meridiana. Essa constância térmica faz com que o tempo seja mais agradável pela manhã, até as 10 horas, e à tarde, depois das 16:30 horas, já que nas horas de maior insolação o termômetro registra mais de $30^{\circ} \mathrm{C}$. Assim sendo, existe maior amplitude térmica diária do que anual, pela madrugada a temperatura comumente baixa e, mesmo antes do nascer do sol, ela pode chegar próximo de $20^{\circ} \mathrm{C}$.

Belém situa-se numa das área mais chuvosas do Brasil, com Indices anuais superiores a $2.000 \mathrm{~mm}$, não existindo uma repartição uniforme de chuvas durante o ano. 


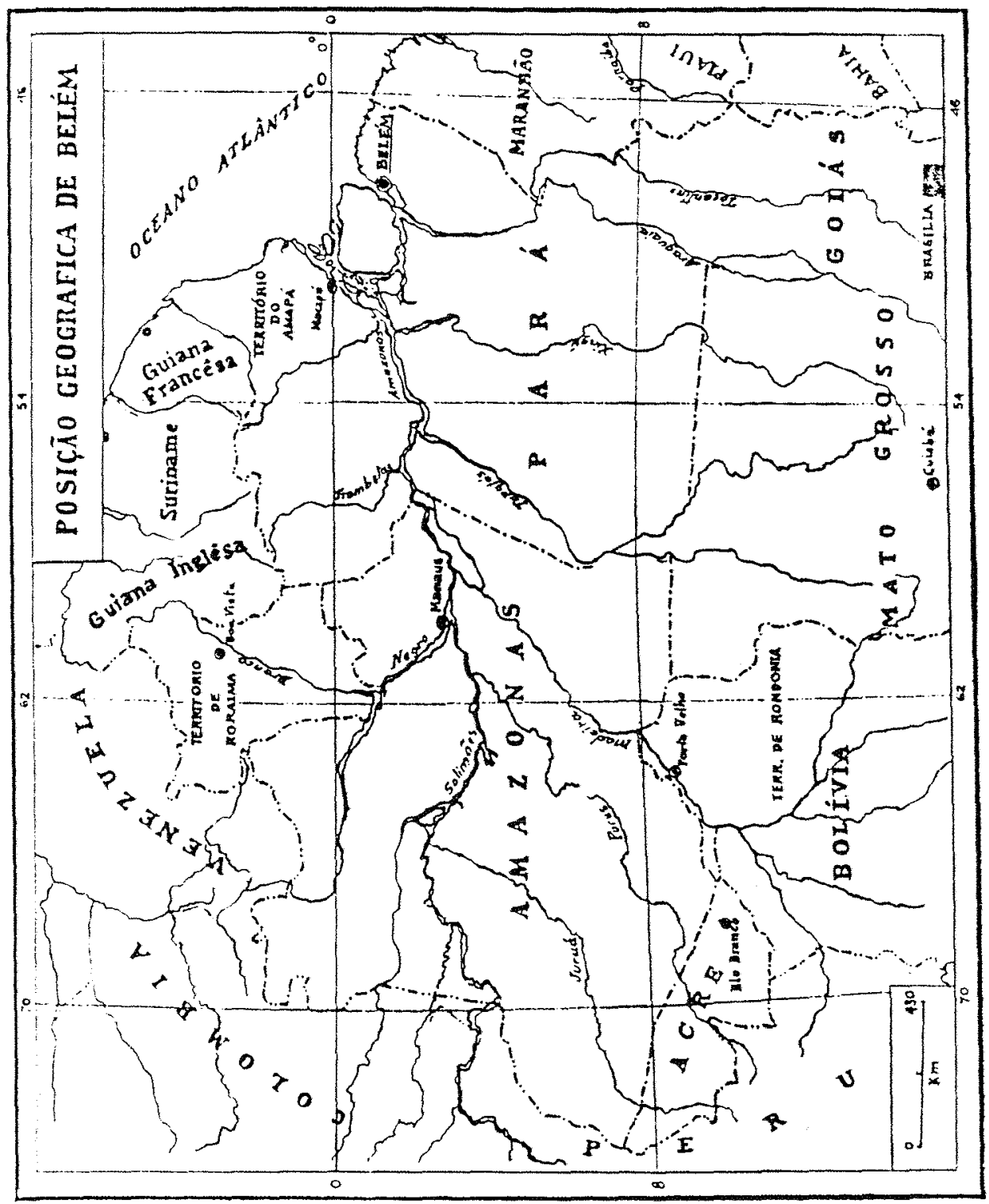

Figura 1 - Localização de Belém em relação ao espaço amazônico (PENTEADO, 1971). 


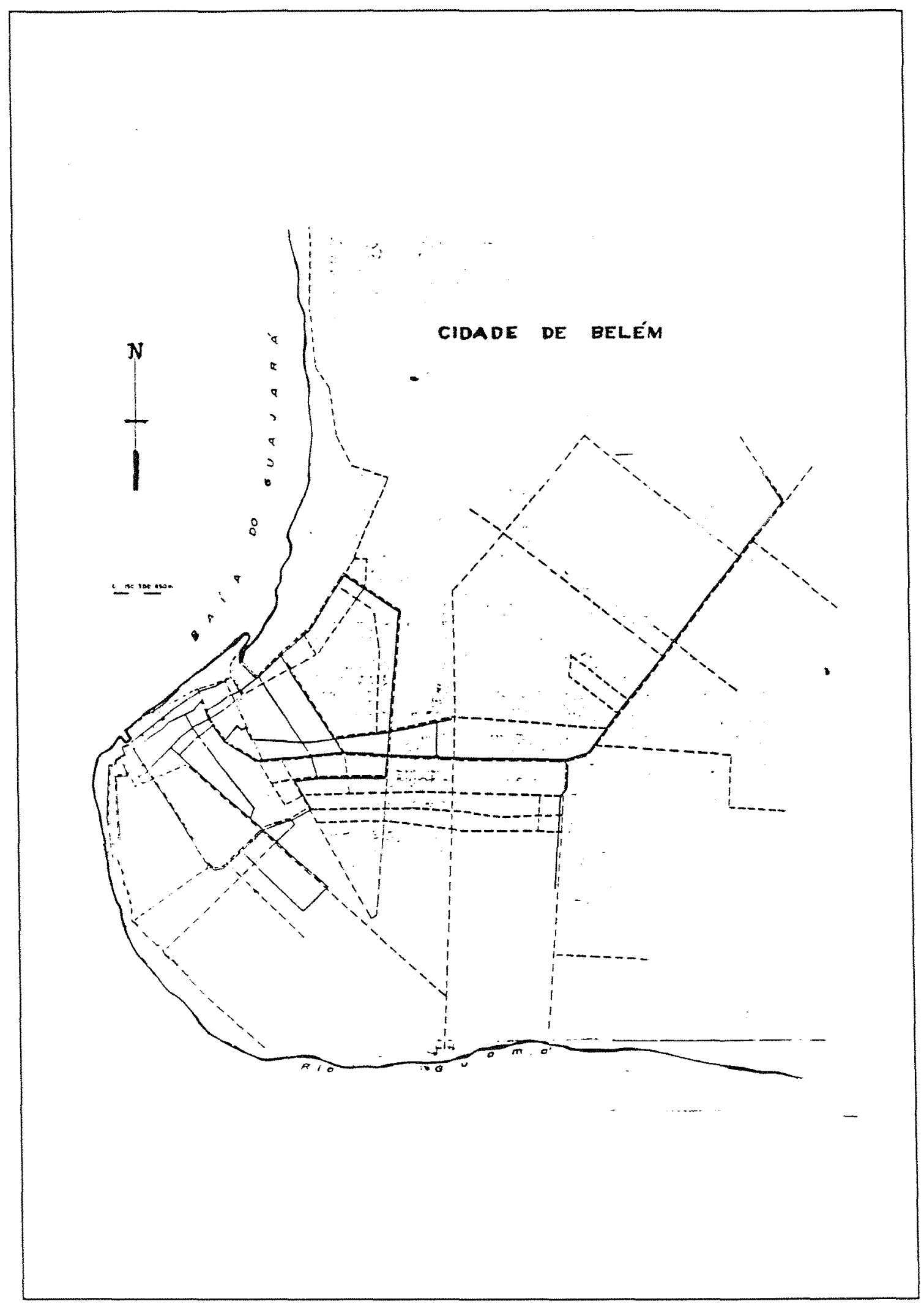

Figura 2 - Localização do sitio urbano da cidade de Belém (PENTEADO, 1971). 
Não havendo variações, como já assinalado, na amplitude térmica no clima da cidade, "suficientes para dividir o ano em estações distintas, estas se reduzem a dois períodos: 0 das chuvas e o menos chuvoso, mais ou menos acentuados e invadindo, em parte, um ao outro, conforme o ano; o primeiro é denominado Inverno Tropical, que vai de dezembro a maio, e o segundo de verão Tropical, que vai de junho a novembro" (PENTEADO, 1971).

Não resta dúvida de que o clima de Belém se enquadra entre aqueles que são quentes: no entanto, o regime de chuvas tem sofrido variações no decorrer dos anos, sendo este fato objeto de estudo deste trabalho.

A umidade relativa média do ar sempre superior a $80 \%$, favorece a formação de chuvas de conveç̧ão local, processo que se evidencia após a insolação máxima diaria, "durante a tarde ou princípio da noite" (NECHET, 1984), característica da estação menos chuvosa, o que não significa que não ocorrem outras genese de chuva em diferentes momentos do dia ou da noite.

Em resumo, o clima de Belém pode ser classificado segundo Koppen, como Tropical Chuvoso, sem período seco definido, do tipo Afi.

A região metropolitana de Belém engloba os municipios de Ananindeua, Benevides e Barcarena, cuja produção agrícola compreende culturas temporárias (abacaxi, arroz, cana-de-açúcar, feijão, mandioca e milho) e culturas permanentes (banana, seringueira, cacau, coco da Bahia, 
dendê, laranja, mamão, maracujá, pimenta do reino, tangerina e urucum) .

Considerando que a região metropolitana de Belém, devido à sua condição geográfica regional, é reconhecidamente um ponto estratégico no abastecimento de gêneros alimentícios e importante pólo de pesquisa agrícola da Região Amazônica, é que o presente estudo objetiva estudar detalhadamente a série de dados meteorológicos observados em Belém - PA desde 1896 até 1991 (registros mensais) e de 1967 até 1991 (registros diários), com intuito de se entender a dinâmica das variações climáticas não só entre anos, mas também para verificar se existe alguma tendência nos registros climáticos da região. Essa análise será feita principalmente com os valores extremos de temperatura visto que os valores médios suavizam as tendências e flutuações. A distribuição das chuvas a nível diário também foi estudada detalhadamente. Tais informações servirão de apoio, dentre outras coisas, para a realização de um planejamento agrícola adequado. 


\section{2 - REVISÃo DE LITERATURA}

A Iiteratura em Meteorologia Tropical mune-se de um número de explicações dentro das causas e dos efeitos para variações climáticas que ocorrem no norte da Amazônia.

Nos trópicos, o parâmetro climatológico mais importante a ser considerado é a chuva. BASTos (1990), pesquisando o zoneamento agroclimático para áreas desmatadas no Estado do Pará, relatou que na Amazônia a chuva é responsável pelas principais flutuações de temperatura e umidade do ar, sendo considerado, por causa de sua grande variabilidade, o fator principal que controla a sua produção agrícola.

A causa física da variabilidade interanual de chuva na Amazônia ainda não é bem conhecida, mas sem dúvida está relacionada às flutuações da circulação de grande escala, principalmente à intensidade da alta pressão na troposfera superior, que está associada à variação da potência das fontes de calor (liberação de calor latente) sobre os continentes tropicais. Isso tornou-se mais evidente a partir do monitoramento da cobertura espacial através de satélites geoestacionários, pois oferecem melhores condições para a determinação da estrutura do escoamento troposférico 
sobre regiões com escassez de dados.

KOUSKY \& KAGANO (1981) analisando radiossondagens de Manaus e Belém, para o período de 1968 a 1976, observou que nos níveis superiores os dados de altura geopotencial e vento, mostraram que a variação sazonal da intensidade e da posição da alta pressão na troposfera superior está diretamente relacionada com a distribuição espacial e temporal da chuva.

Em particular, anos que apresentaram grande redução nos totais pluviométricos anuais parecem ter sido anos de ocorrência de eventos fortes de oscilação meridional e El Niño.

Antes de fazer comentários sobre o fenômeno Oscilação sul - El Niño, torna-se necessário relatar sobre a circulação de Walker. A natureza meridional do escoamento de verão é resultado direto do forte aquecimento da superficie com liberação de calor sensivel e de calor latente, este último devido à condensação do vapor através de toda coluna troposférica. Este aquecimento produz uma célula de circulação direta forçada termicamente com ar quente e úmido subindo (conveç̧ão) sobre o continente e ar seco descendo (subsidência) sobre as áreas oceânicas adjacentes. Segundo GILL ${ }^{2}$, citado por MOLION (1987), contudo, o ramo leste da componente zonal desta circulação,

${ }^{2}$ GILL, A.E. Some simple solutions for heat-induced tropical circulation. Quart. J. Roy. Meteor. Soc., 106, 447-462. 1980. 
conhecida como circulação de Walker, pode ser mais extenso que o ramo oeste. Portanto, a subsidência ocorre sobre grande área a leste do centro de ascensão. No caso da América do Sul, o movimento subsidente estende-se desde o leste da Amazônia até o oeste da África, incluindo a parte do Nordeste do Brasil. O ramo ascendente desta circulação de Walker provoca desenvolvimento intenso de nuvens convectivas e alto indices de chuva, enquanto o ramo descendente inibe a formação de nuvens e chuva.

As primeiras referências ao El Niño datam do século XVIII. Quase todos os anos, na época do Natal, as costas do Peru e Equador, caracterizadas por áquas muito frias e pela pesca farta, costumam ser invadidas por águas quentes. Essas águas natalinas, que afugentam os cardumes de atum e de outros peixes da região, foram batizadas pelos pescadores com o nome de El Niño, numa alusão ao menino Jesus. Em geral, a variação da temperatura é pequena e dura pouco. Hoje, falamos em El Niño apenas quando $\bigcirc$ fenômeno adquire dimensão anormal, com aquecimento da água e duração muito maior do que os usuais (ARANTES, 1992).

- fenômeno Oscilação Sul - El Niño (ENOS) acontece quando uma conveç̧ão mais forte do que a normal estabelece sobre as águas superficiais anomalamente quentes do Pacífico Equatorial Leste. O ramo ascendente da circulação de Walker, que normalmente está sobre a parte ocidental da Amazônia é deslocada para Oeste, sobre o Pacífico, e intensificada pela forte conveç̧ão. o ramo 
descendente estende-se sobre praticamente toda a Amazônia alcançando a costa oeste da África e causando redução nos totais de precipitação (MOLION \& KOUSKY, 1984).

As variações de ENOS são medidas por meio de índices. Um dos indices medidos é a diferença de pressão ao

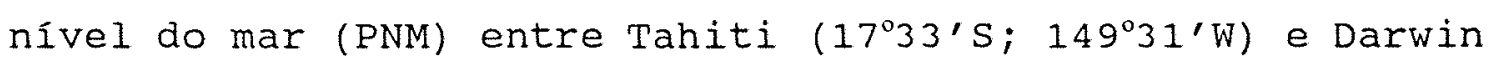
$\left(12^{\circ} 20^{\prime} \mathrm{S} ; 130^{\circ} 52^{\prime} \mathrm{E}\right)$, representando os dois centros de ação. Um episódio quente de ENos produz, em geral, grandes alterações na circulação global da atmosfera. As áreas do globo que apresentam anormalidades periódicas de chuva são mostradas na figura 3 .

Atualmente, pesquisadores de alguns continentes se preocupam em estudar a relação entre ENOS e as alterações na produção agrícola de várias culturas. HANDLER (1984), analisando a relação entre produção de milho do Estado de Illinois (centro produtor de milho dos Estados Unidos da América) e anos de ENos, concluiu que existe uma associação evidente entre ENos e os resultados da produção de milho, alertando para a necessidade de modelagem que explique essa associação.

- impacto do ENOS na produção mundial de cereais foi analisado por FARNETT \& KHANDEKAR (1992), sendo que anos de ocorrência do ENos resultam em seca e baixa produção no sul da Ásia e Austrália, e em alta produção nas planícies da América do Norte e na Argentina. 


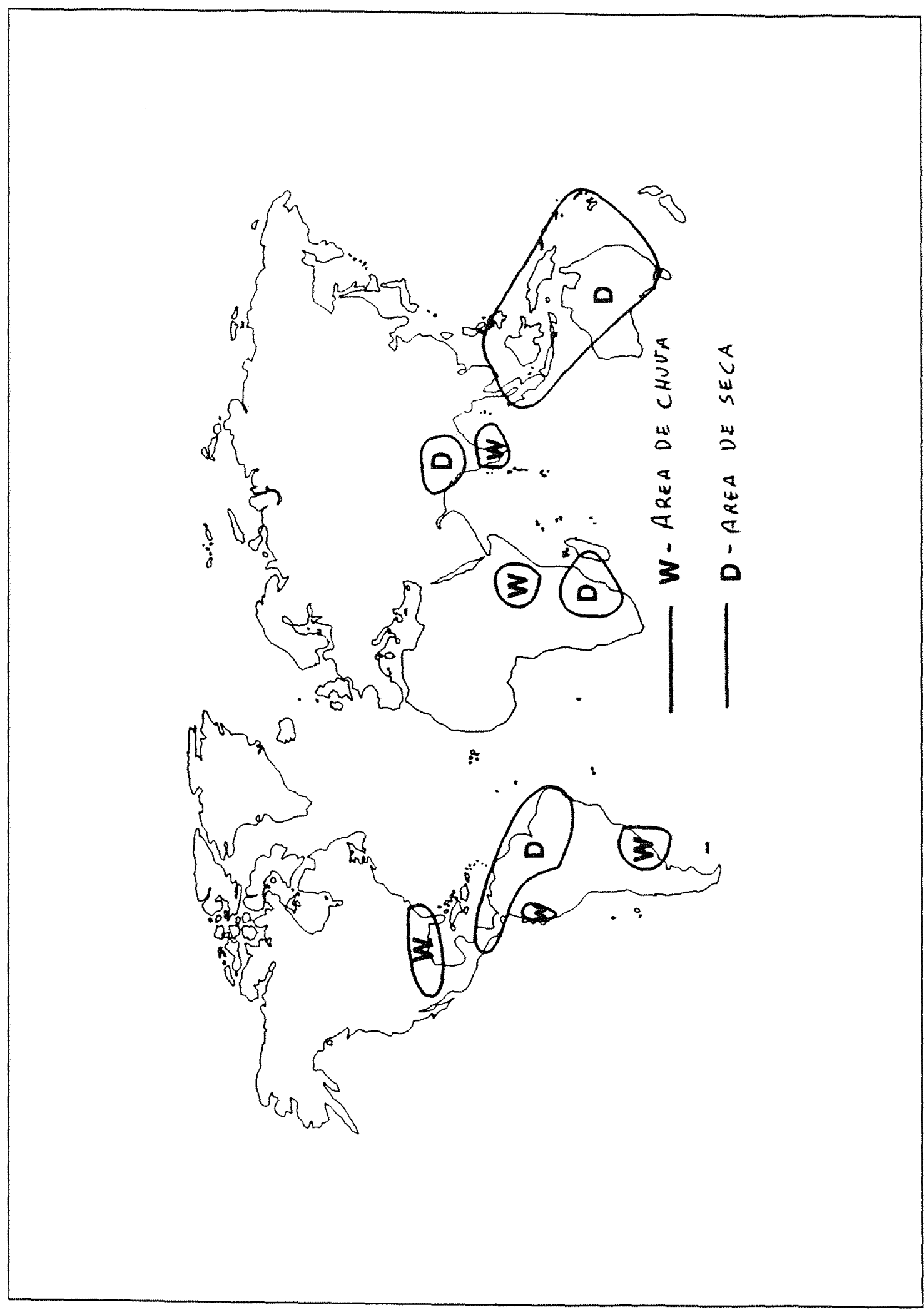

Figura 3 - Áreas do Globo que apresentam anormalidades periódicas, em consequência do ENOS (MARCUS, 1992). 
MARCUS (1992) evidencia que nenhum outro fenômeno tem efeito tão global na variabilidade de chuva e produção de açúcar quanto ENos. O evento El Niño de 1972/73 resultou na redução significante da produção de cana-deaçúcar em importantes áreas produtoras, incluindo India, sul da África e Austrália.

Em 1983, a seca no sul e oeste da África, Austrália e na Índia reduziu as produções de açúcar. Na mesma época, cheias no sul da china e na América do sul prejudicaram a cultura de cana-de-açúcar.

No Brasil, o ENOS provoca, em média, chuva abaixo do normal no norte da região semiárida do Nordeste e na parte oriental da Região Amazônica, inclusive no centronorte do Maranhão, e fortes chuvas na Região sul, principalmente durante o inverno, no Rio Grande do sul.

Os dois últimos episódios de ENOS foram registrados em $1982 / 83$ e 1987 . Tanto a intensidade dos episódios como suas consequências foram diversas nesses dois anos.

Em 1983 ocorreu um dos episódios mais intensos do século, que dificilmente se repetirá a curto prazo. Suas consequências mais imediatas foram grandes cheias no Rio Grande do sul e Santa Catarina, e seca intensa no Nordeste do Brasil. 
KOUSKY et alii', citado por MOLION \& KOUSKY (1984), demonstraram também que o El Niño de 1983 afetou a chuva da Amazônia. o total de chuva para o período de janeiro-maio daquele ano apresentou uma redução média de $30 \%$ para algumas estações na região.

RAO \& HADA (1990) estudaram a relação entre a ENOS e as chuvas no Brasil, verificando a relação pelo cálculo da correlação do coeficiente linear entre o índice de oscilação sul anual e chuva sazonal. Nesse estudo verificaram que para a região Norte os valores da correlação foram positivos crescente até $+0,6$ (signif cante ao nível de $90 \%$ ), mostrando com isso que no Norte no norte do Nordeste do Brasil as diminuiçōes de chuva ocorrem durante os anos de El Niño. Neste sentido, é de fundamental importância o monitoramento destas características, para servirem de subsíduos à prognósticos qualitativos à respeito da quadra chuvosa do setor norte do Nordeste do Brasil e das suas diversas sub-regiões (ALVES \& REPELLI, 1992).

MARTORANO et alii (1992) estudando a variabilidade da precipitação pluviométrica em Belém, associada ao fenômeno "El Niño", concluiu que, nas duas últimas decadas, houve uma tendência no aumento da precipitação, e que valores muito abaixo da normal,

3 KOUSKY, V.E.; KAGANO, M.T \& CAVALCANTI, I.F.A. A review of the southern oscilation: oceanic atmospheric circulation changes and related rainfall anomalies. S. 1., Tellus, 1984. No Prelo. 
caracterizando estiagem prolongada, foram intimamente relacionados com a ocorrência de ENOS.

os sistemas atmosféricos com atividades na região Amazônica, tornam-se mais intensos no verão do hemisfério sul. Deve-se este fato, principalmente ao deslocamento do sol para o hemisfério sul. Com isto, a região passa a receber mais energia solar, ativando os processos convectivos.

CUTRIN \& COHEN (1987), objetivando diagnosticar as causas das chuvas do período chuvoso na região leste do Pará, analisaram uma série de imagens de satélites geoestacionários para identificar os sistemas atmosféricos atuantes na região. Nesse trabalho, observou-se que dez situações atmosféricas são responsáveis pelas chuvas convectivas, as quais são: 1 - Convecção fortalecida pelo vértice ciclônico ou cavado de altitude na região Nordeste do país; 2 - Penetração da zona de Convergência Intertropical (ZCIT) no continente; 3 - Linha de conveç̧ão litorânea causada pela circulação de brisa local; 4 - Linha de instabilidade (linha de convecção litorânea que se propaga para o interior da Amazônia); 5 - Linha de convecção noturna (intensificação dos ventos alíseos); 6 - cumulosnimbos isolados (conveç̧ão local); 7 - Aglomerado de cumulos-nimbos; 8 - Conveç̧ão associada à baixa continental; 9 - Conveç̧ão continental associada a sistemas frontais do hemisfério sul (SFHS); 10 - Convecção organizada por sistemas frontais do hemisfério norte (SFHN). 
Um sistema atmosférico que, por sua atuação direta, exerce importante papel na variação de chuva na região Amazônica é a zona de Convergência Intertropical (ZCIT), que é formada pela junção dos ventos alíseos e pelo intenso aquecimento da faixa equatorial, formando um mecanismo termodinâmico que tem sua interface com massa tropical, sendo responsável pela formação do cinturão de baixas pressões ao redor da Terra. NIMER (1972) cita que a ZCIT tem sua posição média sobre o Hemisfério Norte, porém no inverno, outono e verão, especialmente no outono, ela desce frequientemente para o Hemisfério Sul. Embora ela atinja o sul da região, a grande intereiduce de sua frequência é limitada ao setor norte da ragĩo, sobre o Amapá e norte do Pará.

UVO \& NOBRE (1989) estudaram como a ZCIT influencia qualitativamente a precipitação do Nordeste e os fenômenos que determinam sua posição. Concluiram que a ZCIT é o fator mais importante na determinação da qualidade da estação chuvosa do norte do Nordeste brasileiro, pois a ZCIT determina a duração da estação chuvosa. Um aspecto importante para prever a qualidade da estação chuvosa é observar quando a ZCIT iniciará o seu retorno para o Norte após ter atingido sua posição mais ao sul. A ZCIT aparentemente apresenta flutuações da ordem de 10 a 20 dias, sendo que essas flutuaçōes podem ser causadas por fenômenos de propagação de ondas de leste. 
- Iitoral da região Amazônica sofre bastante influência da brisa marítima. Esta circulação ocorre em resposta ao gradiente horizontal de pressão que é gerada pelo contraste térmico diário entre o continente e o oceano Atlântico. A brisa marítima se desenvolve quando é estabelecida a ascensão do ar no continente, relativamente mais quente do que o oceano, durante o dia. Nos dias atuais, com o emprego de imagens de satélites geoestacionários, verifica-se que é visível a formação de uma linha constituída por cumulos-nimbos junto ao litoral Atlântico. Algumas destas linhas de cumulos-nimbos propagam-se para o interior da bacia Amazônica como linha de instabilidade.

Segundo CUTRIN ${ }^{4}$, citado por COHEN (1989), as linhas de instabilidade mostraram-se responsáveis por aproximadamente $45 \%$ da chuva que cai no leste paraense, durante o período chuvoso de cinco anos analisados.

As linhas de instabilidade da Amazônia formamse ao longo da costa norte - nordeste da América do Sul, desde a Guiana até o Estado do Maranhão.

COHEN (1989), classificou as linhas de instabilidade da Amazônia em dois tipos: Iinha de instabilidade que se propaga (LIP) e linha de instabilidade costeira (LIC). Sendo que as LIC referem-se às Iinhas de cumulos-nimbos que se formam e dissipam na costa, sem se

4 CUTRIN, E.M.C. Informação sobre a contribuição de chuva produzida por linhas de instabilidade no leste paraense. Comunicação pessoal à Julia Cohen, em 10 de agosto 1987 . 
propagar continente a dentro, ou seja, essas Iinhas de instabilidade chegam no máximo a $170 \mathrm{~km}$ (medidos a partir do Ponto Central (PC) da Iinha de instabilidade). A escolha desta dimensão espacial $(170 \mathrm{Km})$ deve-se ao fato de ser esta aproximadamente, a dimensão da Iinha de instabilidade (LI) na direção de propagação (largura da LI). As Iinhas de instabilidade que se propagam continente adentro, foram subdivididas em dois tipos. Para deslocamentos entre 170 e $400 \mathrm{Km}$ foi denominada Iinha de instabilidade com propagação do tipo $1\left(\operatorname{LIP}_{1}\right)$ e para o deslocamento superior a $400 \mathrm{Km}$, linha de instabilidade com propagação do tipo 2 ( $\left.\operatorname{LIP}_{2}\right)$.

Antes de uma Iinha de instabilidade ser classificada como $\operatorname{LIP}_{2}$, sabe-se que ela passou pelo estágio de $\operatorname{LIP}_{1}$. No entanto, para que uma $\operatorname{LIP}_{1}$ torne-se uma $\operatorname{LIP}_{2}$ é necessário $\operatorname{LIP}_{1}$ sofra uma regeneração.

As Iinhas de instabilidade podem ser observadas durante todo o ano, porém a maior freqüência de formação destes sistemas ocorrem entre abril e agosto. Entretanto, as $\mathrm{LIP}_{2}$ apresentam máxima freqüência em julho. A velocidade de propagação média das $\operatorname{LIP}_{1}$ e $\operatorname{LIP}_{2}$ foi de 12 e $16 \mathrm{~m} / \mathrm{s}$, respectivamente. As LIC, LIP ${ }_{1}$ e $\operatorname{LIP}_{2}$ apresentam duração média de 9,12 e 16 horas, respectivamente.

CAVALCANTI 5 , citado por COHEN (1989), analisou

${ }^{5}$ CAVALCANTI, I.F.A. Um estudo sobre interacões entre sistemas de circulacōes de escala sinótica e circulacões locais. Dissertação de Mestrado em Meteorologia. São José dos campos, INPE, jun. 1982. (INPE-2494-TDL/097). 
a interação existente entre as Iinhas de instabilidade e a ZCIT, e verificou que a região de formação das Iinhas de instabilidade sofre deslocamento sazonal semelhante ao da ZCIT. Sendo que as linhas de instabilidade ocorrem no período em que a ZCIT está mais organizada.

MOLION \& KOUSKY (1985) verificaram que as Iinhas de instabilidade na Amazônia formam-se no final da tarde e propagam-se para dentro do continente com uma velocidade média de 10 graus de longitude/dia. Porém, a redução do contraste térmico durante a noite provoca dissipação, podendo tais linhas de instabilidade reiniciar suas atividades no dia seguinte quando o aquecimento na superfície novamente se estabelece. A distribuição anual de chuva mostra um máximo de $3000 \mathrm{~mm}$ junto à costa e um mínimo relativo de $1600 \mathrm{~mm}$ na região de santarém, a $700 \mathrm{~km}$ da costa. De acordo com esses autores, as Iinhas de instabilidade seriam responsáveis pela distribuição média mensal da precipitação na Amazônia, ou seja, ao passarem durante a noite pela região do mínimo anual de chuva, estão com sua atividade convectiva reduzida. No entanto, CoHEN et alii (1989) não aceitam totalmente a sugestão de MOLION \& KOUSKY (1985) de que o mínimo relativo da chuva, na região de Santarém, seria devido ao enfraquecimento da atividade convectiva das linhas de instabilidade durante a madrugada. A climatologia das linhas de instabilidade mostra que o fator principal do máximo junto à costa leste prende-se ao número de linhas de instabilidade que se formam na região 
costeira. Já o número de linhas de instabilidade que atinge a região de Santarém $\left(\operatorname{LIP}_{2}\right)$ é menor, portanto este importante mecanismo dinâmico causador de chuva é menos presente nesta última região. O enfraquecimento noturno das linhas de instabilidade pode ser um fator secundário de redução adicional da precipitação na região de Santarém em relação à precipitação costeira. Porém, este não parece ser - único mecanismo responsável pela manutenção destas linhas de instabilidade, pois existem casos em que a dissipação ocorre em horários de aquecimento. Além disso, nota-se, em alguns casos, a regeneração das LIP $_{2}$ na sua extremidade norte durante o período noturno.

$\mathrm{Na}$ região Amazônica, os sistemas atmosféricos causados pelas perturbações de menor escala são os sistemas convectivos representados por aglomeração de cumulos-nimbos ou por cumulos-nimbos isolados, além de conveç̧ão com formação local (NEVES et alii, 1989).

Nos últimos anos vários autores procuraram desenvolver trabalhos no sentido de atualizar o nivel de informações no campo da climatologia e Meteorologia regional. Alguns desses autores pertencem a instituições que atuam diretamente em pesquisa na região Amazônica. Dentre os quais podemos citar:

1 - INMET - Instituto Nacional de Meteorologia;

2 - DNAEE - Departamento Nacional de Āguas e Energia Elétrica;

3 - SUDAM - Superintendência de Desenvolvimento da Amazônia; 
4 - EMBRAPA - Empresa Brasileira de Pesquisa Agropecuária;

5 - INPA - Instituto Nacional de Pesquisa da Amazônia;

6 - INPE - Instituto de Pesquisas Espaciais;

7 - DEPV - Diretoria de Eletrônica e Proteção ao Vôo;

8 - IDESP - Instituto de Desenvolvimento Econômico e Social do Pará;

9 - UFPa - Universidade Federal de Pará;

10 - ESALQ-USP - Escola Superior de Agricultura "Luiz de Queiroz" - Universidade de São Paulo;

11 - CPRM - Companhia de Pesquisa de Recursos Minerais. BAsTos et alii (1984) descreveram vários segmentos de trabalhos publicados em climatologia e meteorologia na região Amazônica, envolvendo principalmente os seguintes aspectos: caracterização geral do clima da região como um todo, ou por Unidades Federativas e Municipais, envolvendo conjuntamente temperatura e umidade do ar, insolação, chuva, balanço hídrico e classificação climática; análises de elementos climáticos isolados provenientes de mensurações ou de estimativa relacionando principalmente vento e chuva; estimativa e mensuração de radiação solar global e seus componentes, coeficiente de transmissão da radiação, distribuição espectral e luminosidade, bem como estimativas de evapotranspiração potencial e balanço hídrico; resultados de temperatura do ar e do solo provenientes de postos meteorológicos convencionais e envolvendo comparação entre áreas cobertas com florestas e áreas desmatadas, bem como abordando efeitos 
de friagem e resultados de mensurações microclimáticas em florestas, campinas e às proximidades de rios; estudo da relação, chuva e cobertura florestal visando o conhecimento do papel da floresta em possíveis alterações climáticas, empregando pluviômetros convencionais conjuntamente com sistemas de coletores de água escoada pelo tronco e método isotópico em água de chuva.

o estudo de possíveis alterações climáticas na região Amazônica, ultimamente vem sendo objeto de interesse e avaliação de vários autores. FALESI (1982), estudando os fatores climáticos e a fertilidade de solos tropicais, analisou a distribuição do clima da região segundo a classificação de KOPPEN, observando a existência de climas do tipo $A_{f}, A_{m}$ e $A_{w}$. Utilizando os métodos estatísticos de correlaçōes simples, correlações múltiplas e curva de dupla acumulação, na análise e tratamento dos dados climatológicos, tomando-se com base as estações com séries completas de observaçōes (período de 1960 a 1980), o Projeto de Hidrologia e Climatologia da Amazônia desenvolveu o Atlas Climatológico da Amazônia Brasileira, constando de vários mapas dos seguintes parâmetros climáticos: chuva, temperatura, umidade relativa, insolação e classificação climática (SUDAM, 1984). RIBEIRO (1991) analisou tendências de elementos climáticos em séries adequadamente longas de dados para a região de Manaus (AM), com intuito de detectar a existência de possiveis tendências e ciclos. 
As informações sobre direção e velocidade do vento na região Amazônica são bastante reduzidas. A rede de observações do ar superior por meio de radiossondas se restringe as estações de Belém, Manaus e Vilhena. o vento horizontal, por se tratar de uma grandeza vetorial, pode ser decomposto em duas componentes: zonal e meridional.

MARQUES et alii (1978) estudando os ventos em altitude sobre Belém e Manaus, a partir de informaçōes de 364 e 294 sondagens aerológicas, respectivamente, as quais foram realizadas diariamente as 12:00 horas GMT (9:00 local), verificaram que os ventos em altitude apresentam uma componente zonal, tanto em Manaus como em Belém, no sentido Leste para oeste durante todo o ano e em todos os níveis de altitude. Para ambas as localidades os valores máximos encontram-se próximos aos 1500 metros e ocorrem nos meses de março e setembro. Devido ao atrito com a superfície florestada, os valores máximos registrados em Belém foram superiores aos valores máximos registrados em Manaus. A componente do vento na direção meridional apresenta em Belém, até a altitude de 600 metros aproximadamente, sentido de norte para sul nos meses de janeiro a abril e de julho a dezembro. Entre os níveis de 3150 e os 5860 metros, em janeiro e fevereiro, o sentido também foi de norte para sul. Em Manaus, o sentido norte-sul predominou de janeiro a março e de outubro a dezembro, desde próximo a superfície até a altitude de 3150 metros, sendo que em janeiro e fevereiro, esta dominância estabelece-se até 5500 metros. Notou-se que, 
para as localidades estudadas, os valores da componente zonal foram superiores aos da componente meridional e que em Belém eles foram superiores aos de Manaus, evidenciando a predominância da circulação latitudinal na área.

BASTOS \& DINIZ (1985) analisando dados obtidos na Estação Meteorológica do INMET, referente ao período de 1970 a 1979, avaliaram o potencial eólico da localidade de Soure-PA, que pela sua posição geográfica (Iimitada ao norte com o oceano Atlântico e a Este com a baía do Marajó), atribui-se a hipótese de dispor de energia eólica favorável para o emprego de máquinas movidas a vento. Verificou que tais máquinas eólicas podem ser utilizadas em considerável período do ano, principalmente nos meses de setembro, outubro e novembro.

Para a Amazônia o oceano Atlântico tem papel importante como fonte de ar quente e úmido, e também notável contribuição nos padrões de tempo que acontecem na região, sendo um dos grandes contribuidores pelo aumento de umidade a nível regional. Funciona também, como uma fonte constante e alimentadora de vapor d'água, para a região.

MARQUES (1976) estudando o ciclo hidrológico da Amazônia, utilizando um volume hipotético em uma faixa que vai de Belém a Manaus, concluiu que: o suprimento de vapor para a região estudada foi predominantemente zonal e no sentido Leste-Oeste, contribuindo a camada $1000 / 700 \mathrm{mb}$ com $80 \%$ do total do vapor; o fluxo zonal total em Manaus foi cerca de $80 \%$ do fluxo zonal em Belém; os valores de fluxo 
zonal em Belém, quando comparados mês a mês com os de Manaus, apresentam valores superiores ( $1 \%$ a $57 \%$ ), exceto nos meses de outubro e novembro, quando os valores em Manaus foram superiores em $1 \%$ e $7 \%$, respectivamente; $\circ$ fluxo meridional em Belêm, foi predominantemente no sentido sulnorte e a camada $1000 / 700 \mathrm{mb}$ contribuiu com $68 \%$ do total de vapor meridional; o fluxo de vapor meridional em Manaus, apresentou uma alternância semestral no seu sentido, sendo norte-sul de outubro a março e sul-norte nos demais meses: - total de vapor transportado no sentido norte-sul foi superior ao transportado no sentido contrário; em Manaus, apesar do fluxo meridional de vapor total ter sido bastante inferior ao zonal, parece evidente a importância do fluxo norte-sul na manutenção da chuva na área, coincidindo sua atuação com a época de valores máximos de chuva.

Durante todo o ano a bacia Amazônica recebe uma entrada maciça de vapor d'água oriunda do oceano. No entanto, o fluxo vai diminuindo gradativamente, devido à diminuição da velocidade do vento pois há um aumento dos valores da umidade específica à medida que maior penetração se verifica (MARQUES et alii, 1979). As figuras 4 a 7 evidenciam essa penetração. Considera $\vec{Q}=\vec{Q} \lambda+\vec{Q} \phi$, onde $\vec{Q}$ é o fluxo total de vapor, $\vec{Q} \lambda$ é o componente zonal e $\vec{Q} \phi$ é a componente meridional do fluxo de vapor. Essas figuras mostram também as isolinhas de água precipitável na região. 


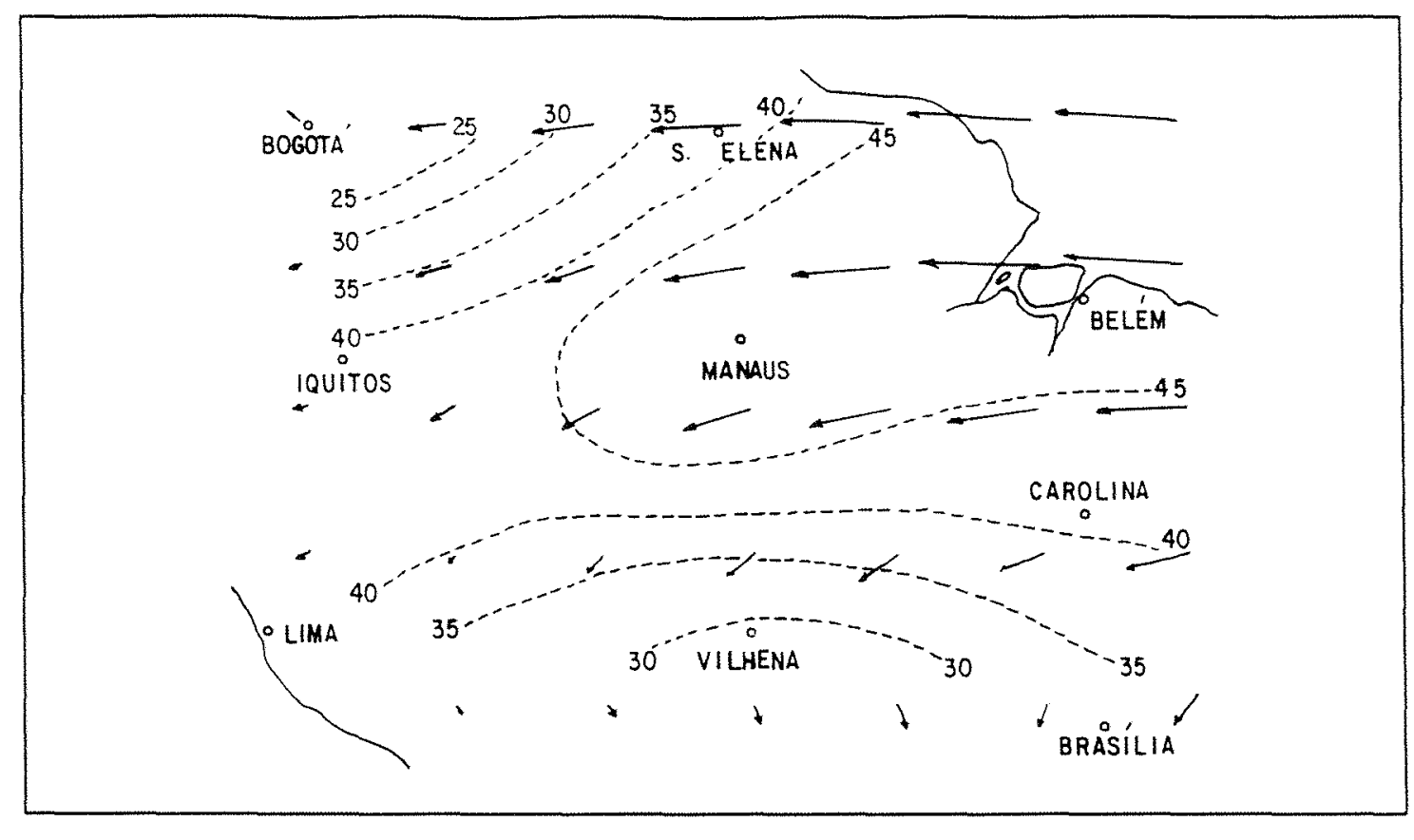

Figura 4 - Valores do campo vetorial $\vec{Q}=\overrightarrow{Q_{\lambda}}+\overrightarrow{Q_{\phi}}$. Média do período 1972/1975, obtida para as quadriculas de $5^{\circ}$ de latitude por $5^{\circ}$ de longitude. Valores para março. Linhas tracejadas: água precipitável, em $\mathrm{mm} .1 \mathrm{~cm}=2000 \mathrm{gv} / \mathrm{cm} . \mathrm{s}$. (MARQUES et alii, 1979).

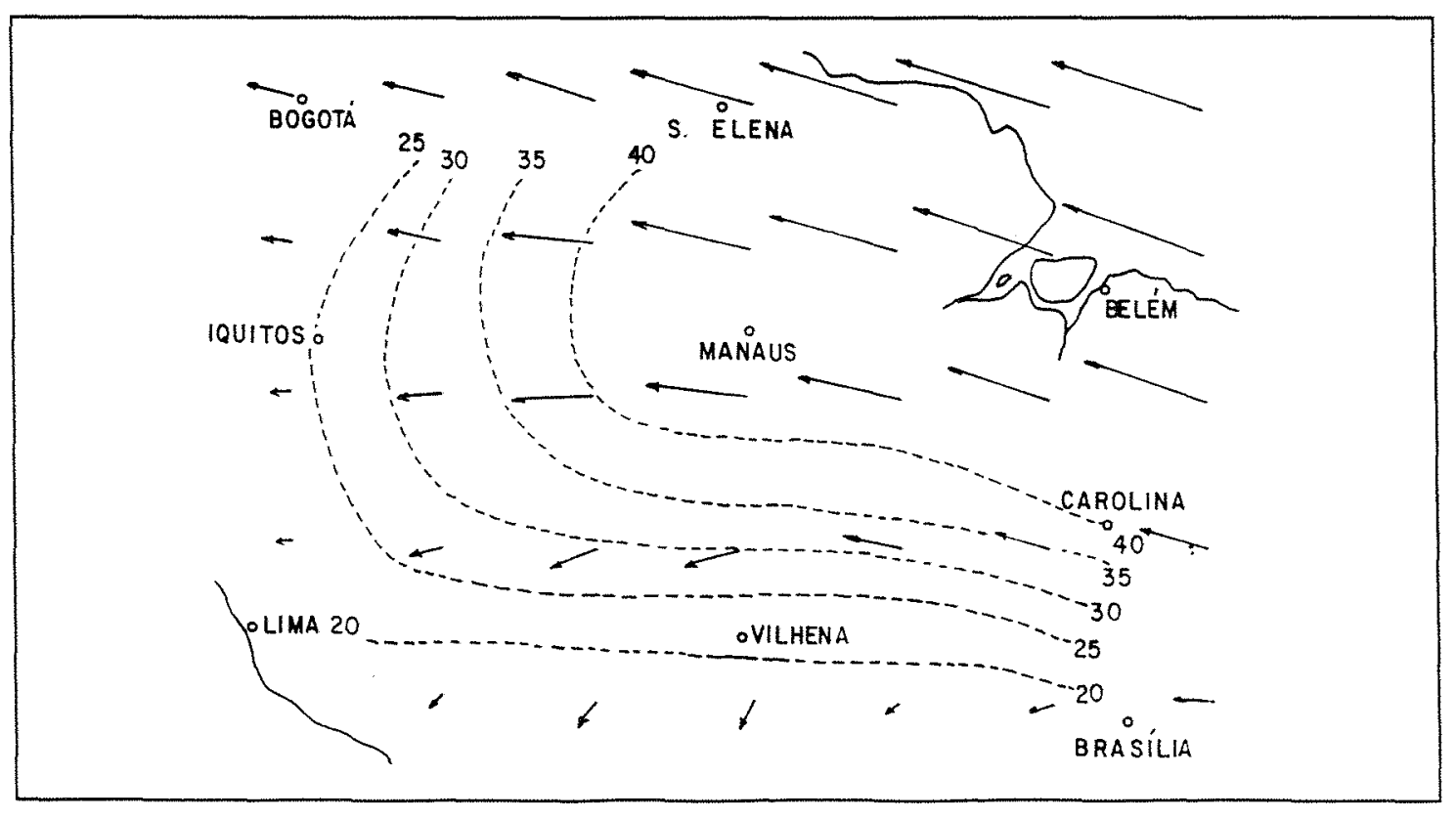

Figura 5 - Valores do campo vetorial $\vec{Q}=\overrightarrow{Q_{\lambda}}+\overrightarrow{Q_{\phi}}$. Média do período 1972/1975, obtida para as quadriculas de $5^{\circ}$ de latitude por $5^{\circ}$ de longitude. Valores para junho. Linhas tracejadas: água precipitável, em $\mathrm{mm} .1 \mathrm{~cm}=2000 \mathrm{gv} / \mathrm{cm} . \mathrm{s}$. (MARQUES et alii, 1979). 


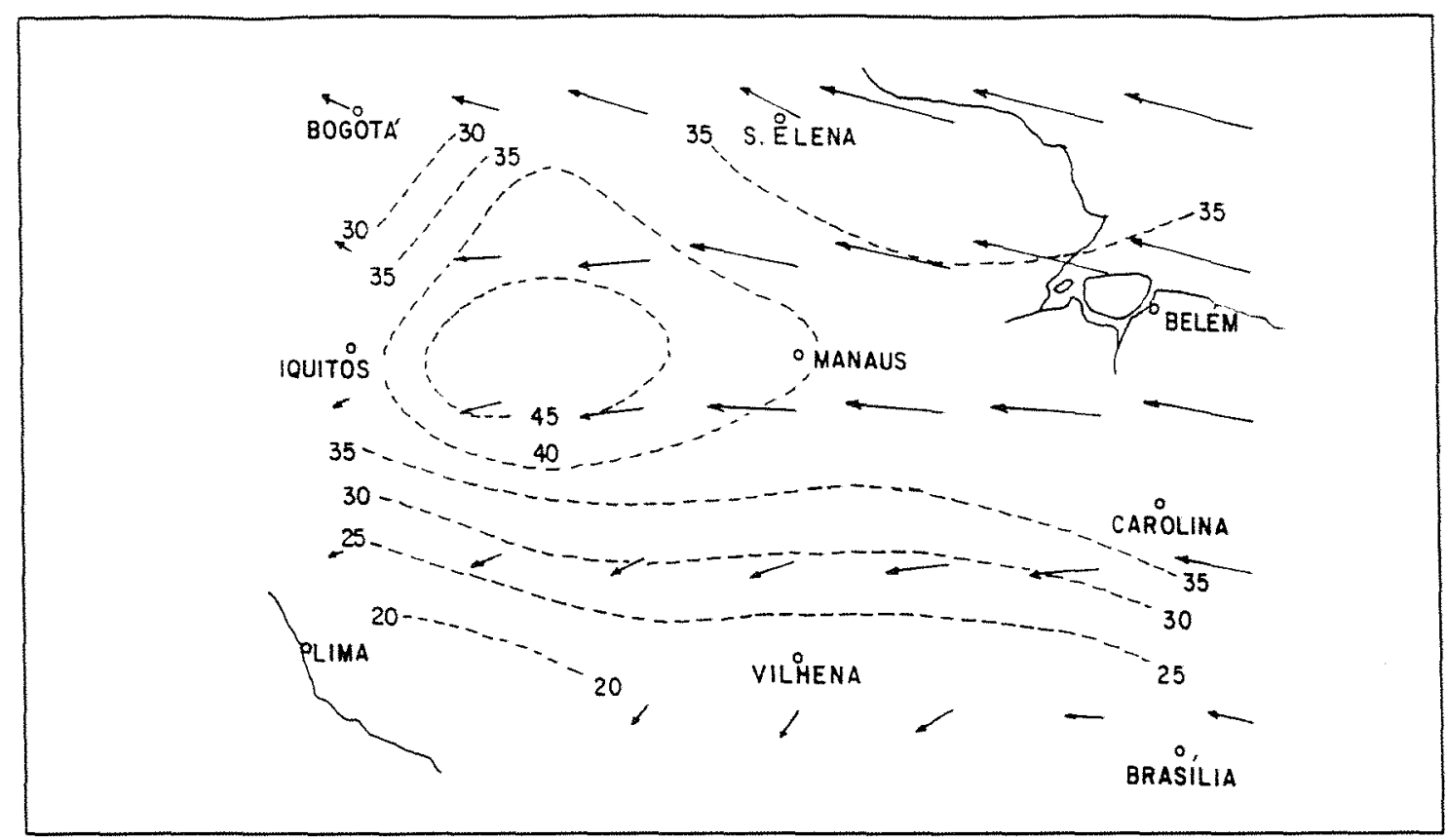

Figura 6 - Valores do campo vetorial $Q=Q_{\lambda}+Q_{\phi}$. Média do período 1972/1975, obtida para as quadriculas de $5^{\circ}$ de latitude por $5^{\circ}$ de longitude. Valores para setembro. Linhas tracejadas: água precipitável, $\mathrm{em} \mathrm{mm} .1 \mathrm{~cm}=2000 \mathrm{gv} / \mathrm{cm} . \mathrm{s}$. (MARQUES et alii, 1979).

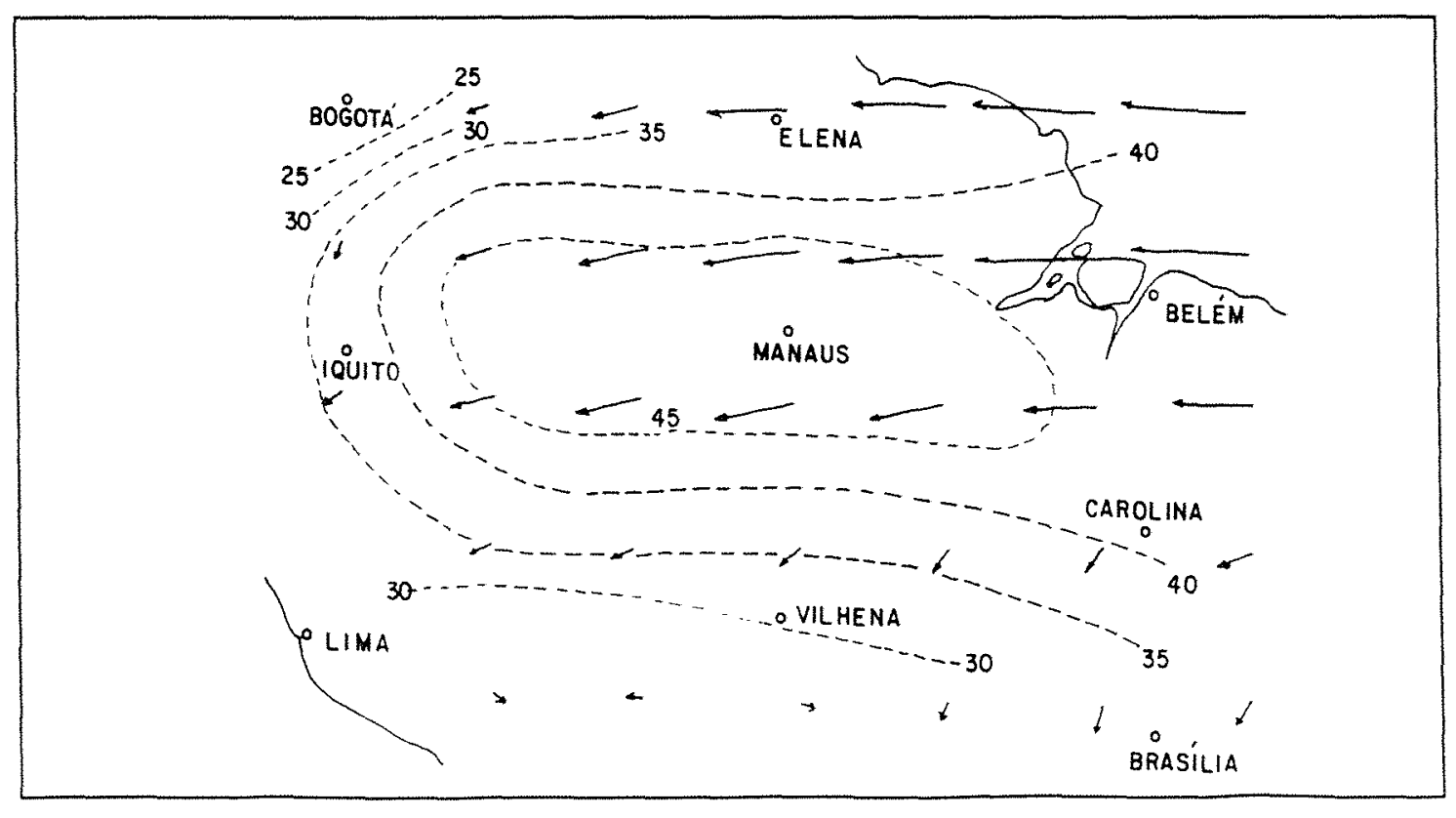

Figura 7 - Valores do campo vetorial $Q=Q_{\lambda}+Q_{\phi}$. Média do período 1972/1975, obtida para as quadriculas de $5^{\circ}$ de latitude por $5^{\circ}$ de longitude. Valores para dezembro. Linhas tracejadas: água precipitável, $\mathrm{em} \mathrm{mm} .1 \mathrm{~cm}=2000 \mathrm{gv} / \mathrm{cm} . \mathrm{s}$. (MARQUES et alii, 1979). 
Segundo BENWELL 6 , citado por MARQUES et alii (1979), o termo "água precipitável" não pode ser considerado como a quantidade de água que pode ser precipitada mediante um processo físico qualquer. Para fins práticos, entretanto, a água precipitável contida na troposfera pode ser considerada como suficientemente representativa do vapor d'água disponível para o processo de precipitação.

A água precipitável existente em uma coluna vertical da atmosfera é, por definição, a massa total de água que seria obtida se todo o vapor d'água da coluna de área unitária se condensasse em um plano horizontal. De um modo mais genérico, a água precipitável representa o armazenamento atmosférico de água sobre uma dada região.

os ventos alíseos, que introduzem na região Amazônica o vapor d'água proveniente do oceano Atlântico, tem barreiras naturais especialmente no semi-círculo andino, que impõe uma precipitação do vapor d'água através de chuva ou de neve, Assim as características geomorfológicas e a localização da região interceptando os ventos quentes e úmidos da circulação geral da atmosfera e a convergência intertropical levam a uma resultante que tende a determinar um clima quente e úmido (SALATI et alii, 1979).

A precipitação é um dos elementos meteorológicos que exerce mais influência sobre as condições

${ }^{6}$ BENWELL, $W$. The estimation and variability of precipitable water. The Meteor. Mag., London, 94(1120): 319-327, 1965. 
ambientais. É o elemento regulador na agricultura, sendo que a quantidade de chuva que cai em uma localidade determina o tipo de atividade agrícola a ser desenvolvida.

Na Amazônia oriental, a região de Belém, por ser conhecida como uma das regiões mais chuvosas da Amazônia brasileira e abrigar grande contingente de pesquisa agrícola do Estado do Pará, vem apresentando bastante interesse por parte de autores na realização de trabalhos voltados para a caracterização da chuva.

Em Belém a variabilidade diurna da chuva pertence ao tipo "Continental". O horário de maior ocorrência varia das 14:00 horas (março e abril) até 19:00 (junho e julho), sendo que na primeira coinzenza do mês de outubro apresenta períodos sem precipitaçấ (NECHET, 1984) .

BASTOS et alii (1984) estudaram a flutuação das chuvas na região de Belém em distintos intervalos de tempo, analisando registros de precipitação diária agrupados em períodos: qüinquiidial, semanal, quinzenal, mensal e anual. os resultados obtidos foram referentes à precipitação média, desvio padrão, coeficiente de variação, assimetria ou grau de afastamento de uma distribuição de freqüência e ocorrência máxima de precipitação a níveis de $5 \%, 25 \%, 50 \%, 75 \%$ e $95 \%$ de probabilidade. Foi observado que houve predominância de reduzidos somatórios de chuva a partir da segunda metade do ano, havendo também ocorrência de reduzidos somatórios em períodos correspondentes ao primeiro trimestre do ano que assinalou, como era de se 
esperar o maior percentual sobre o total pluviométrico anual, mostrando com isso a necessidade do produtor agrícola ficar atento para eventuais ocorrências de estiagem em pleno período chuvoso, e que resultarão em necessidade de irrigação, para garantir o suprimento continuo de água para culturas susceptíveis a pequenas deficiências hídricas como hortaliças e plantas em viveiros.

De acordo com RIEHL (1954), "na faixa equatorial é o ciclo de temperatura diurna que governa os hábitos da vida através do ano".

De fato, nas latitudes equatoriais, sobre o continente a variação diurna da temperatura excede de muito em relação a amplitude estacional. Tomando por base a média das máximas e das mínimas diárias verifica-se que a média da amplitude térmica diurna na região durante o ano, varia entre 8 e $14^{\circ} \mathrm{C}$ (NIMER, 1972).

No entanto, não se percebe a presença de variaçōes estacionais no decorrer do ano, sendo portanto a região caracterizada pela uniformidade térmica. Entretanto, trabalhos voltados para caracterização de regimes de temperatura na região tem evidenciado que a idéia generalizada do domínio das temperaturas elevadas e uniformidade térmica não se aplica a todas as áreas da região (BASTOS et alii, 1984).

A temperatura do ar tem grande importância no desenvolvimento e crescimento de espécies vegetais cultivadas. 
No Estado do Pará apesar da pequena variabilidade anual, um estudo detalhado da distribuição das unidades térmicas poderá dar grande subsidios à prática agrícola no Estado (COSTA et alii, 1990). SANTOS (1991), pesquisando a distribuição das unidades térmicas na Amazônia, observou que na região há variação na distribuição do número de graus-dias nas direções leste-oeste e sulnorte, e que os baixos valores que ocorrem no mês de junho em todos as localidades da região é devido a estação de inverno.

Os aumentos significativos de temperatura são encontrados nos registros climáticos de inúmeras cidades do mundo. Em muitas localidades essas tendências tem sido mais uma expressão dos efeitos urbanos locais do que aquecimento global. A urbanização afeta os registros longos de temperatura nos mais diferentes graus, e o crescimento das ilhas de calor produz incremento significativo nos registros climatológicos.

Os registros de temperaturas médias mensais das cidades de Belém e Manaus foram analisados por SANSIGolo et alii (1990) visando detectar, através de cálculo por regressão linear, a existência e magnitude de tendências significativas no aumento de temperatura a longo prazo. Belém apresentou tendências significativas a 95\%, pelo teste de Kendall, sendo encontrados os valores $(0,007$ e 0,012 ${ }^{\circ} \mathrm{C} / \mathrm{ano}$, considerados baixos. No caso de Manaus, esse estudo não apresentou tendência significativa. 
RIBEIRO (1991), analisando as séries das temperaturas máximas e mínimas absoluta da cidade de Manaus, verificou que a temperatura mínima absoluta variou muito pouco em todos os meses do ano, permanecendo entre 19 e $21^{\circ} \mathrm{C}$, ao passo que a máxima apresentou tendência de aumentar, estando na maioria dos casos respondendo a um aumento na precipitação.

As informações de variabilidade espacial dos principais elementos meteorológicos, nos últimos anos, vem sendo objeto de estudo intensificado na região Amazônica brasileira. No entanto, os estudos disponíveis na região, ainda não atingiram um nível para que possa tornar essas informações mais efetivas na compatibilidade da tecnologia gerada com a realidade climática da Amazônia. 


\section{3 - MATERIAL E MÉTODO}

Para este trabalho, utilizou-se toda a série de dados de chuva e temperaturas absolutas extremas existentes para a região de Belém - PA, assim como o índice de temperatura da superfície do mar no Pacífico Sul,

Os valores de altura de chuva mereal, número de dias de chuva e temperaturas máxima e mínima absoluta do mês, foram analisadas para o período de 1896 a 1991. A análise dos dados diários de chuva compreendeu o perído de 1967 a 1991.

A série de dados do período de 1896 a 1922 foram obtidos através da publicação a "Contribuição do Museu Paraense Emílio Goeldi à Meteorologia na Amazônia" (CUNHA \& BAstos, 1973). A estação climatológica de Belém foi mantida pela direção do Museu Emilio Goeldi até 31 de dezembro de 1922 e a partir de janeiro de 1923 passou a pertencer ao Ministério da Agricultura, funcionando em próprios do Museu até 1932 .

Atualmente a estação meteorológica de Belém, de número 82191 , pertence ao Instituto Nacional de Meteorologia - INMET, localizando-se na latitude de 01027' S e a longitude de $48^{\circ} 28^{\prime} W$. 
Os indices de temperatura da superfície do mar no Pacífico Sul (Anomalia de Temperatura) foram obtidos através da publicação periódica mensal CLIMANÁLISE, no período de janeiro de 1987 a dezembro de 1991.

Com os dados de chuva mensal foram calculados: a média, a distribuição anual, os valores extremos mensais e o máximo em 24 horas.

Através de histogramas mensais com intervalos de classes de $5 \mathrm{~mm}$, são mostradas as distribuições de frequências relativas da intensidade das chuvas diárias para - período considerado, sendo também apresentados as frequências de dias sem chuva.

As tendências das temperaturas absolutas extremas e dos totais mensais de chuva foram calculados através de regressão linear para todo o período e também calculado em três períodos distintos, os quais foram: primeiro período (1896 a 1991), segundo período (1931 a 1960), terceiro período (1961 a 1991).

A anomalia de temperatura representa o desvio da temperatura da superficie do mar no Pacífico sul em relação a sua média climatológica. No presente trabalho utilizou-se os dados de El Niño da região "1+2", por ser sua área de abrangência entre $0^{\circ}$ a $10^{\circ}$ de latitude sul e $90^{\circ}$ a $80^{\circ}$ de longitude Oeste e por ser essa área caracterizada como de influência no deslocamento do ramo ascendente da circulação de walker. 
Para correlacionar a chuva mensal de Belém com as anomalias de temperatura utilizou-se o índice de chuva ICB, o qual é dado pela seguinte expressão:

$$
I C B=\frac{T C M-C M M}{C M M}
$$

onde:

ICB é o índice de chuva em Belém;

TCM é o total de chuva mensal;

CMM é a chuva média mensal. 


\section{4 - Resultado e discussão}

\subsection{Chuva Mensal}

A série de registros de chuva de Belém no período de 1896 a 1991, mostra que não existe uma repartição igualitária durante o decorrer do ano. No entanto, ocorre registro de chuva durante todos os meses do ano. A tabela 1 é um demostrativo da chuva em Belém.

Tabela 1 - Registro mensal de chuva (mm)

ESTAÇÃO METEOROLOGICA DE BELÉM - REGISTRO DE CHUVA (mm)

\begin{tabular}{|c|c|c|c|c|c|c|c|c|c|c|c|c|}
\hline \multirow[t]{2}{*}{ MESES } & REGISTROS & \multicolumn{2}{|c|}{$S$ MENSAIS } & \multicolumn{2}{|c|}{ DE CHUVA } & \multirow{2}{*}{$\begin{array}{l}\text { CHUVA } \\
\text { V.MÁX }\end{array}$} & \multirow{2}{*}{$\begin{array}{l}\text { MÁXIMA } \\
\text { ANO }\end{array}$} & \multirow{2}{*}{\multicolumn{2}{|c|}{$\begin{array}{l}\text { EM } 24 \text { HORAS } \\
\text { V.MIN ANO }\end{array}$}} & \multirow{2}{*}{$\begin{array}{l}\text { NÜMERO } \\
\text { MÉD IO }\end{array}$} & \multirow{2}{*}{$\begin{array}{l}\text { DE DIAS } \\
\text { MÁXIMO }\end{array}$} & \multirow{2}{*}{$\begin{array}{l}\text { DE CHUVA } \\
\text { MÍNIMO }\end{array}$} \\
\hline & MÉD IO & MÁXIMO & ANO & MINIMO & ANO & & & & & & & \\
\hline JAN & 342.5 & 684.5 & 1964 & 170.8 & 1906 & 118.0 & 1971 & 19.2 & 1951 & 26 & 31 & 18 \\
\hline FEV & 390.1 & 776.2 & 1980 & 204.6 & 1925 & 206.0 & 1909 & 26.0 & 1925 & 26 & 28 & 20 \\
\hline MAR & 420.9 & 802.4 & 1924 & 219.3 & 1909 & 136.9 & 1985 & 25.0 & 1915 & 28 & 31 & 21 \\
\hline$A B R$ & 361.1 & 581.2 & 1953 & 171.7 & 1903 & 131.3 & 1896 & 25.8 & 1919 & 27 & 30 & 18 \\
\hline MAI & 277.1 & 545.2 & 1935 & 109.6 & 1919 & 125.6 & 1935 & 20.8 & 1919 & 25 & 31 & 15 \\
\hline JUN & 171.3 & 333.0 & 1910 & 73.3 & 1918 & 85.4 & 1988 & 10.4 & 1918 & 21 & 29 & 12 \\
\hline JUL & 158.4 & 338.6 & 1913 & 29.3 & 1991 & 110.0 & 1974 & 10.7 & 1966 & 18 & 29 & 6 \\
\hline AGO & 123.8 & 304.7 & 1896 & 25.4 & 1954 & 80.4 & 1969 & 8.6 & 1898 & 15 & 27 & 5 \\
\hline SET & 119.1 & 256.6 & 1989 & 28.1 & 1991 & 71.3 & 1917 & 7.3 & 1991 & 17 & 25 & 8 \\
\hline OUT & 99.0 & 279.7 & 1978 & 13.5 & 1903 & 65.4 & 1978 & 5.5 & 1903 & 15 & 27 & 5 \\
\hline NOV & 92.0 & 307.4 & 1988 & 6.4 & 1903 & 110.0 & 1956 & 3.0 & 1903 & 13 & 24 & 2 \\
\hline DEZ & 183.3 & 384.3 & 1989 & 40.9 & 1969 & 141.5 & 1907 & 12.3 & 1936 & 19 & 28 & 10 \\
\hline ANO & 2733.2 & 3786.9 & 1989 & 2024.7 & 1903 & & & & & & & \\
\hline
\end{tabular}


Conforme podemos observar no quadro demostrativo, a chuva média anual em Belém é de $2733.2 \mathrm{~mm}$, sendo que o ano mais chuvoso foi de 1989 com $3786.9 \mathrm{~mm}$ e o menos chuvoso foi o de $1903 \mathrm{com} 2024.7 \mathrm{~mm}$.

A análise das figuras 8 e 9 evidencia que realmente Belém é uma das cidades do país que apresenta uma das maiores quantidades de chuva.

Nota-se que a partir de abril ocorre uma diminuição uniforme das chuvas. No entanto, a partir de junho essa diminuição é bastante sensível. Observa-se que, em outubro e novembro atingem seus índices menores. Novembro apresenta-se como o mês menos chuvoso, com índice médio de chuva de $92,0 \mathrm{~mm}$.

A partir de dezembro ocorre um aumento uniforme das chuvas, sendo que de janeiro a abril verifica-se a existência do quadrimestre mais chuvoso. Março apresenta-se como o mês mais chuvoso do ano, com índice médio de chuva de $420,9 \mathrm{~mm}$.

Em Belém, essa distribuição média de chuva não representa uma regra geral, pois se estudarmos isoladamente os máximos valores de chuva mensal, observa-se que ocorre uma desuniformidade entre os meses do ano. Contrariando essa situação, os mínimos valores de chuva mensal, acompanham a uniformidade da média mensal de chuva. o menor registro mensal de chuva é de 6,4 mm em novembro de 1903 e o maior registro é de $802,4 \mathrm{~mm}$ em março de 1924 . 


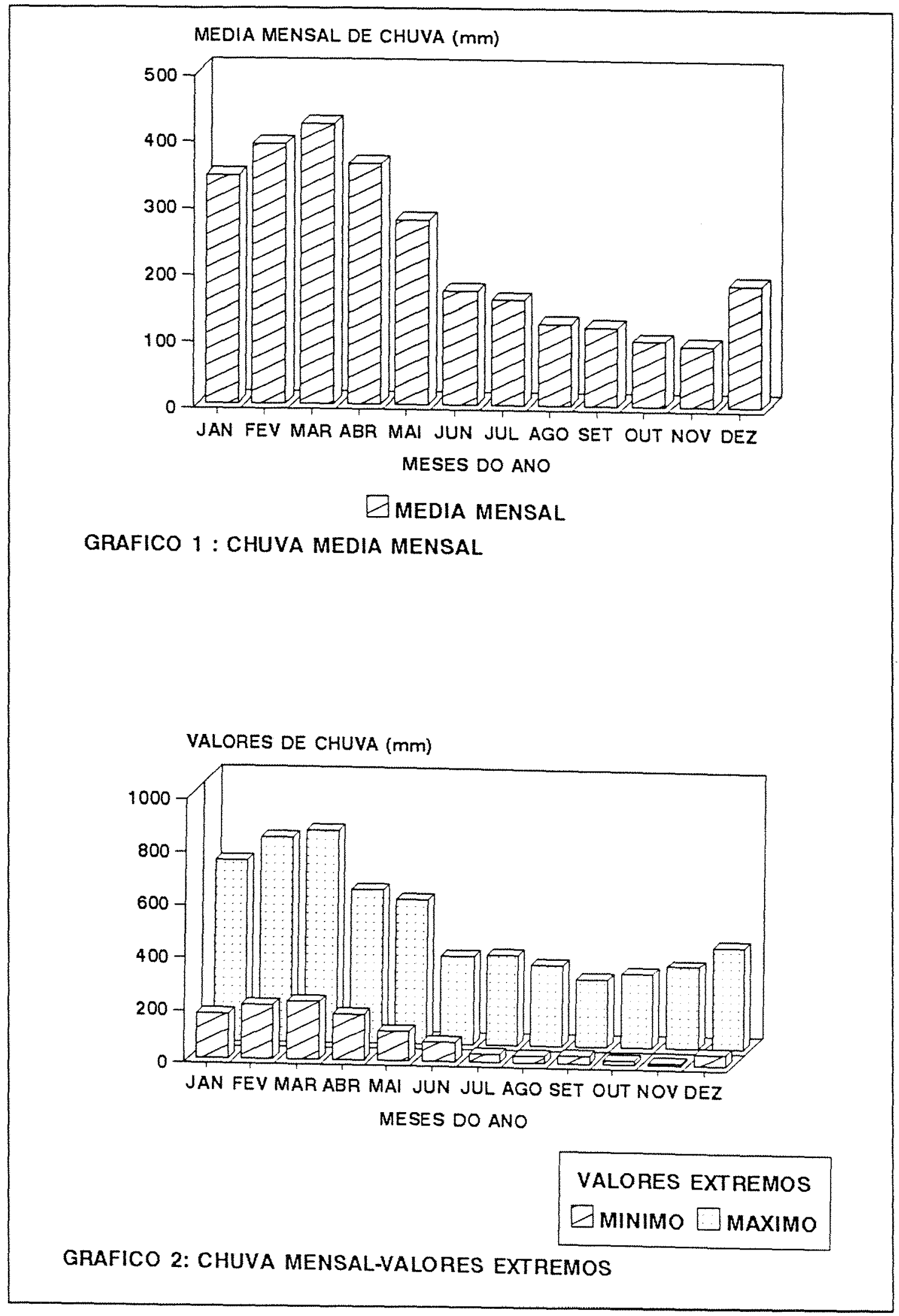

Figura 8 - Gráficos demonstrativos. 


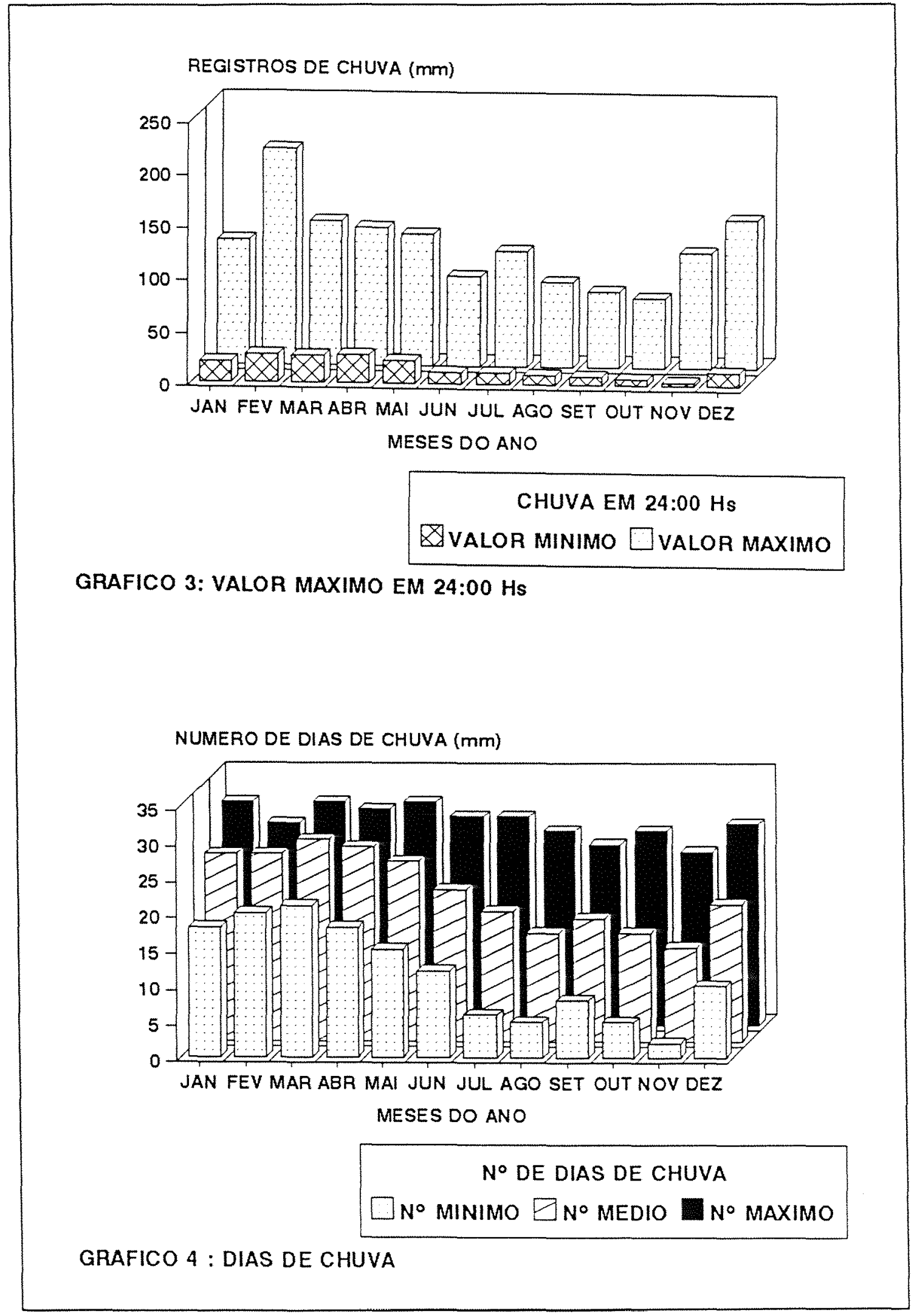

Figura 9 - Gráficos demonstrativos. 
A variabilidade da chuva em Belém, torna-se mais evidente quando se analisa os dados diários.

observando-se, ainda, a distribuição das chuvas máximas em 24 horas nota-se que seguidamente nos meses de janeiro, fevereiro, março, abril, maio, julho e dezembro, houve registros de chuva que superaram as médias mensais de outubro e novembro. Os registros variam de $206,0 \mathrm{~mm}$ em fevereiro de 1909 até $110,0 \mathrm{~mm}$ em julho de 1974. Para efeito de compreensão observa-se na Tabela 1 , que a média mensal de chuva de outubro e novembro são de $99,0 \mathrm{~mm}$ e $92,0 \mathrm{~mm}$, respectivamente.

Seguidamente, de janeiro a maio, o número médio de dias chuvosos, sempre é igual ou superior a 25 dias por mês nesta época do ano, e é reduzido para 13 dias, no mês de novembro.

\subsection{Chuva Diária}

Os valores de números de ocorrência e percentual de intensidade de chuva diária obtida na distribuição de frequência são mostrados nas tabelas 2 e 3 . Analisando a distribuição de frequência da intensidade mensal de chuva, de 1967 a 1991, observa-se que no primeiro trimestre do ano (JFM), no mês de fevereiro, do total de 678 dias analizados, somente 57 dias não apresentaram chuva ou seja aproximadamente $8,4 \%$ dos dias. Março apesar de ser considerado, em média, o mês mais 
chuvoso do ano, apresenta valor percentual de dias sem chuva maior que fevereiro, ou seja, dos 775 dias analizados, 77 dias não apresentaram chuva, esse valor corresponde aproximadamente $9,9 \%$ dos dias. Essa diferença pode ser justificada pelo fato de que, em anos chuvosos, no mês de fevereiro, a ZCIT se localiza na latitude próxima de Belém, consequentemente aumentando o número de dias chuvosos (UVo \& NOBRE, 1989).

Tabela 2 - Valores de frequência de classe da chuva ocorrida no período: $1967-1991$

\begin{tabular}{lrrrllllllllllll}
\hline MES & S/CHU & $0-5$ & $5-10$ & $10-15$ & $15-20$ & $20-25$ & $25-30$ & $30-35$ & $35-40$ & $40-45$ & $>45$ & $\begin{array}{c}\text { TOTAL DE } \\
\text { DIAS }\end{array}$ \\
\hline JAN & 111 & 219 & 120 & 87 & 63 & 38 & 23 & 22 & 16 & 11 & 34 & 744 \\
FEV & 59 & 184 & 110 & 74 & 61 & 59 & 31 & 24 & 29 & 13 & 36 & 678 \\
MAR & 77 & 233 & 126 & 77 & 66 & 68 & 36 & 26 & 14 & 9 & 43 & 775 \\
ABR & 77 & 265 & 113 & 93 & 66 & 33 & 20 & 28 & 15 & 12 & 28 & 750 \\
MAI & 135 & 282 & 103 & 80 & 64 & 37 & 20 & 21 & 11 & 4 & 18 & 775 \\
JUN & 241 & 276 & 88 & 64 & 31 & 21 & 8 & 8 & 5 & 4 & 4 & 750 \\
JUL & 299 & 242 & 96 & 53 & 32 & 15 & 19 & 9 & 4 & 1 & 5 & 775 \\
AGO & 360 & 226 & 73 & 41 & 33 & 15 & 10 & 7 & 4 & 2 & 4 & 775 \\
SET & 296 & 242 & 91 & 53 & 33 & 9 & 11 & 6 & 3 & 3 & 3 & 750 \\
OUT & 399 & 207 & 70 & 39 & 31 & 10 & 7 & 4 & 3 & 1 & 4 & 775 \\
NOV & 381 & 221 & 61 & 34 & 17 & 16 & 5 & 5 & 6 & 3 & 1 & 750 \\
DEZ & 265 & 248 & 88 & 49 & 44 & 19 & 23 & 10 & 7 & 10 & 12 & 775 \\
\hline
\end{tabular}

Tabela 3 - Valores percentuais das classes de chuva ocorrente no período: 1967-1991.

\begin{tabular}{lrrrrrrrrrrrl}
\hline MES & S/CHU & $0-5$ & $5-10$ & $10-15$ & $15-20$ & $20-25$ & $25-30$ & $30-35$ & $35-40$ & $40-45$ & $>45$ & $(*)$ \\
\hline JAN & 14.9 & 29.4 & 16.1 & 11.7 & 8.5 & 5.1 & 3.1 & 3.0 & 2.2 & 1.5 & 4.6 & 43.4 \\
FEV & 8.4 & 27.1 & 16.2 & 10.9 & 9.0 & 8.7 & 4.6 & 3.5 & 4.3 & 1.9 & 5.3 & 45.6 \\
MAR & 9.9 & 30.1 & 16.3 & 9.9 & 8.5 & 8.8 & 4.6 & 3.4 & 1.8 & 1.2 & 5.6 & 46.1 \\
ABR & 10.3 & 35.3 & 15.1 & 12.4 & 8.8 & 4.4 & 2.7 & 3.7 & 2.0 & 1.6 & 3.7 & 47.5 \\
MAI & 17.4 & 36.4 & 13.3 & 10.3 & 8.3 & 4.8 & 2.6 & 2.7 & 1.4 & 0.5 & 2.3 & 45.0 \\
JUN & 32.1 & 36.8 & 11.7 & 8.5 & 4.1 & 2.8 & 1.1 & 1.1 & 0.7 & 0.5 & 0.5 & 41.7 \\
JUL & 38.6 & 31.2 & 12.4 & 6.8 & 4.1 & 1.9 & 2.5 & 1.2 & 0.5 & 0.1 & 0.6 & 41.0 \\
AGO & 46.5 & 29.2 & 9.4 & 5.3 & 4.3 & 1.9 & 1.3 & 0.9 & 0.5 & 0.3 & 0.5 & 38.9 \\
SET & 39.5 & 32.3 & 12.1 & 7.1 & 4.4 & 1.2 & 1.5 & 0.8 & 0.4 & 0.4 & 0.4 & 38.2 \\
OUT & 51.5 & 26.7 & 9.0 & 5.0 & 4.0 & 1.3 & 0.9 & 0.5 & 0.4 & 0.1 & 0.5 & 36.5 \\
NOV & 50.8 & 29.5 & 8.1 & 4.5 & 2.3 & 2.1 & 0.7 & 0.7 & 0.8 & 0.4 & 0.1 & 37.9 \\
DEZ & 34.2 & 32.0 & 11.4 & 6.3 & 5.7 & 2.5 & 3.0 & 1.3 & 0.9 & 1.3 & 1.5 & 41.5 \\
\hline
\end{tabular}

(*) Água precipitável - Fonte: SALATI \& MARQUES (1984). 
No trimestre menos chuvoso do ano (SON), no mês de outubro, do total de 775 dias analizados, 399 dias não apresentaram chuva ou seja aproximadamente $51,5 \%$ dos dias. Novembro considerado, em média, o mês menos chuvoso do ano, apresenta valor percentual de dias sem chuva menor que outubro, ou seja, dos 750 dias analizados, 381 dias não apresentaram chuva, esse valor corresponde aproximadamente $50,8 \%$ dos dias. Isto pode ser explicado pelo fato dessa época do ano apresentar precipitação basicamente de convecção local e pela constatação do que na primeira quinzena de outubro não ocorre precipitação no horário das 0:00 às 11:00 horas (NECHET, 1984), consequentemente outubro apresenta maior número de dias sem chuva.

Nas figuras de 10 a 15 são relatadas a distribuição das frequências de precipitação mensal para intervalos de classe de $5 \mathrm{~mm}$.

Em todos os meses apresentaram-se dias de chuva de até $40 \mathrm{~mm}$ (figura 16). No entanto, verifica-se que o maior percentual de chuva é menor ou igual ao Iimite de $10 \mathrm{~mm} / \mathrm{dia}$. Os efeitos locais em Belém, ocorrem de janeiro a janeiro, no entanto, nos meses de dezembro, janeiro, fevereiro, março, abril e maio ocorre uma intensificação da chuva em consequência da ZCIT. 


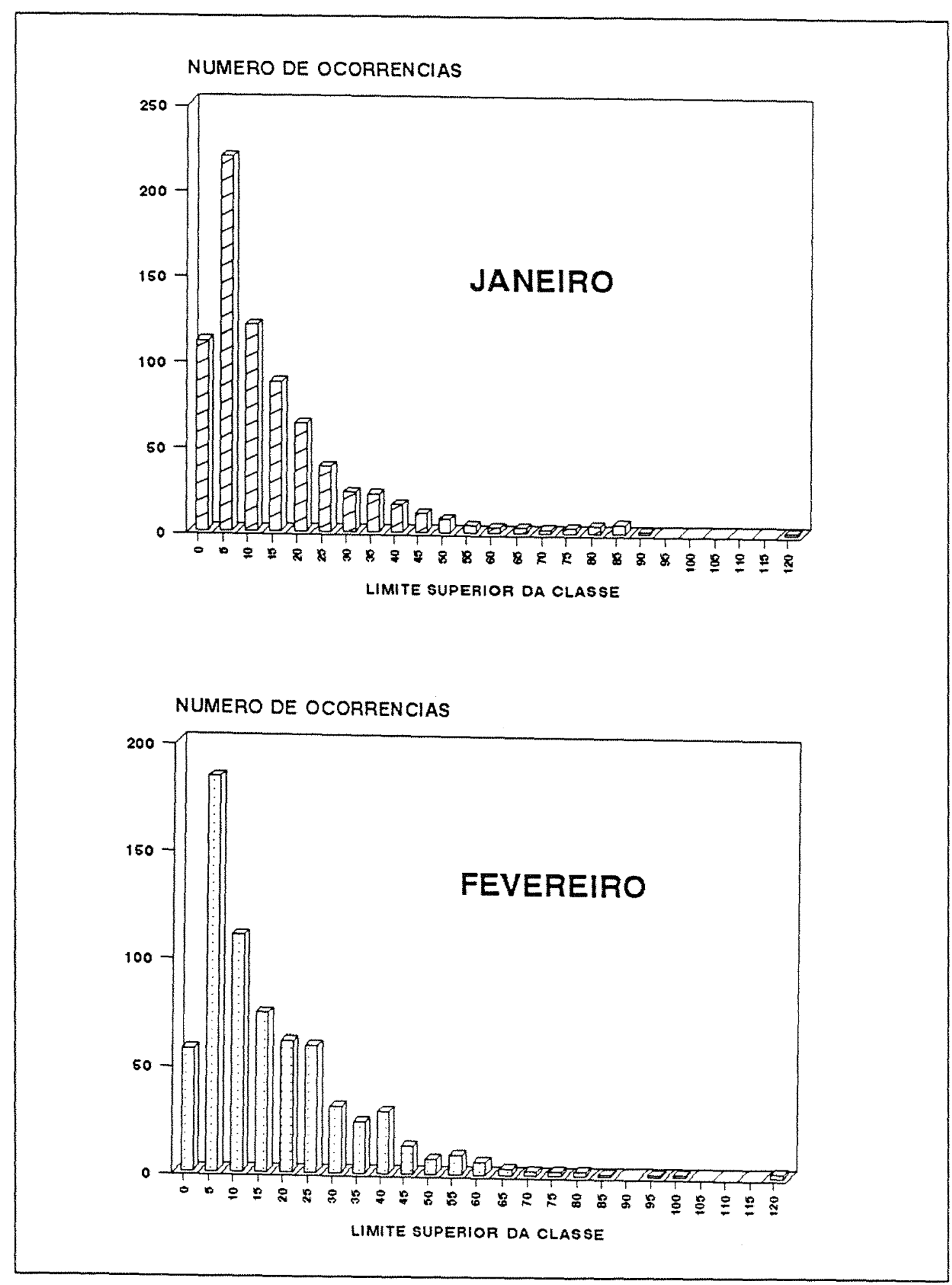

Figura 10 - Distribuição de frequência da intensidade de chuva no período 1967 a 1991 dos meses janeiro e fevereiro, sendo representada a frequência de dias sem chuva (classe 0). Fonte de dados brutos: INMET. 


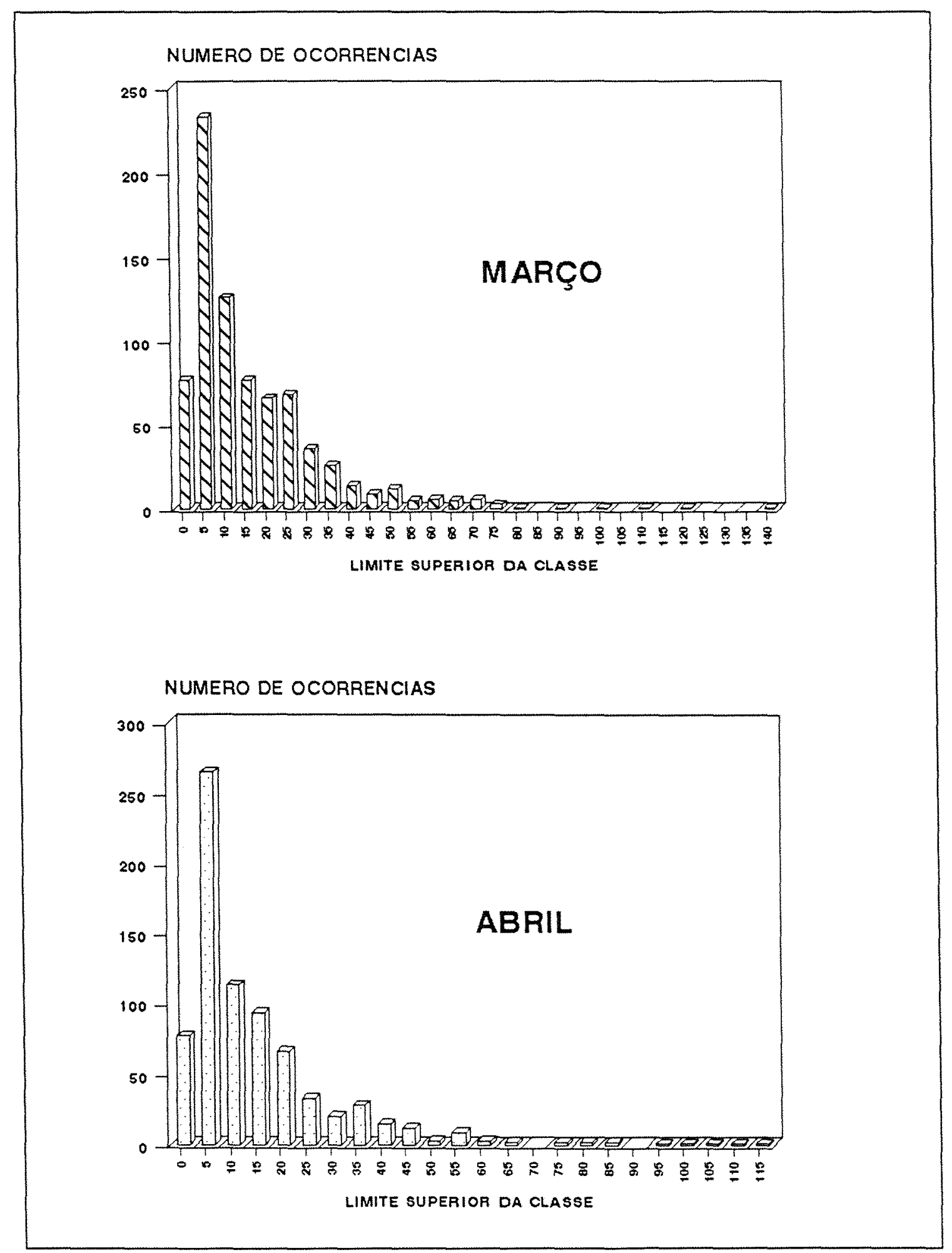

Figura 11 - Distribuição de frequência da intensidade de chuva no período 1967 a 1991 dos meses março $e$ abril, sendo representada a frequência de dias sem chuva (classe 0 ). Fonte de dados brutos: INMET. 


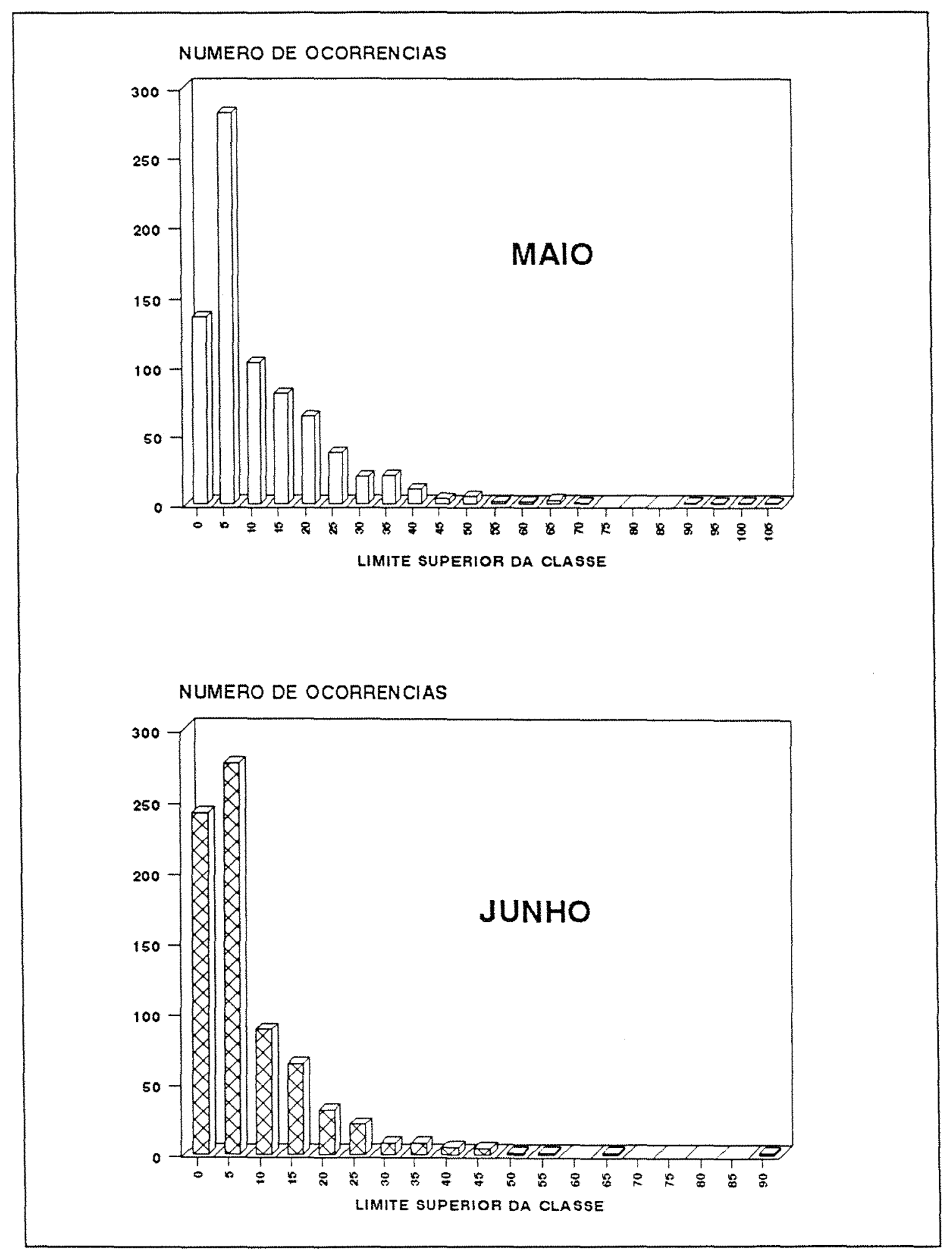

Figura 12 - Distribuição de frequência da intensidade de chuva no período 1967 a 1991 dos meses maio e junho, sendo representada a frequência de dias sem chuva (classe 0 ). Fonte de dados brutos: INMET. 


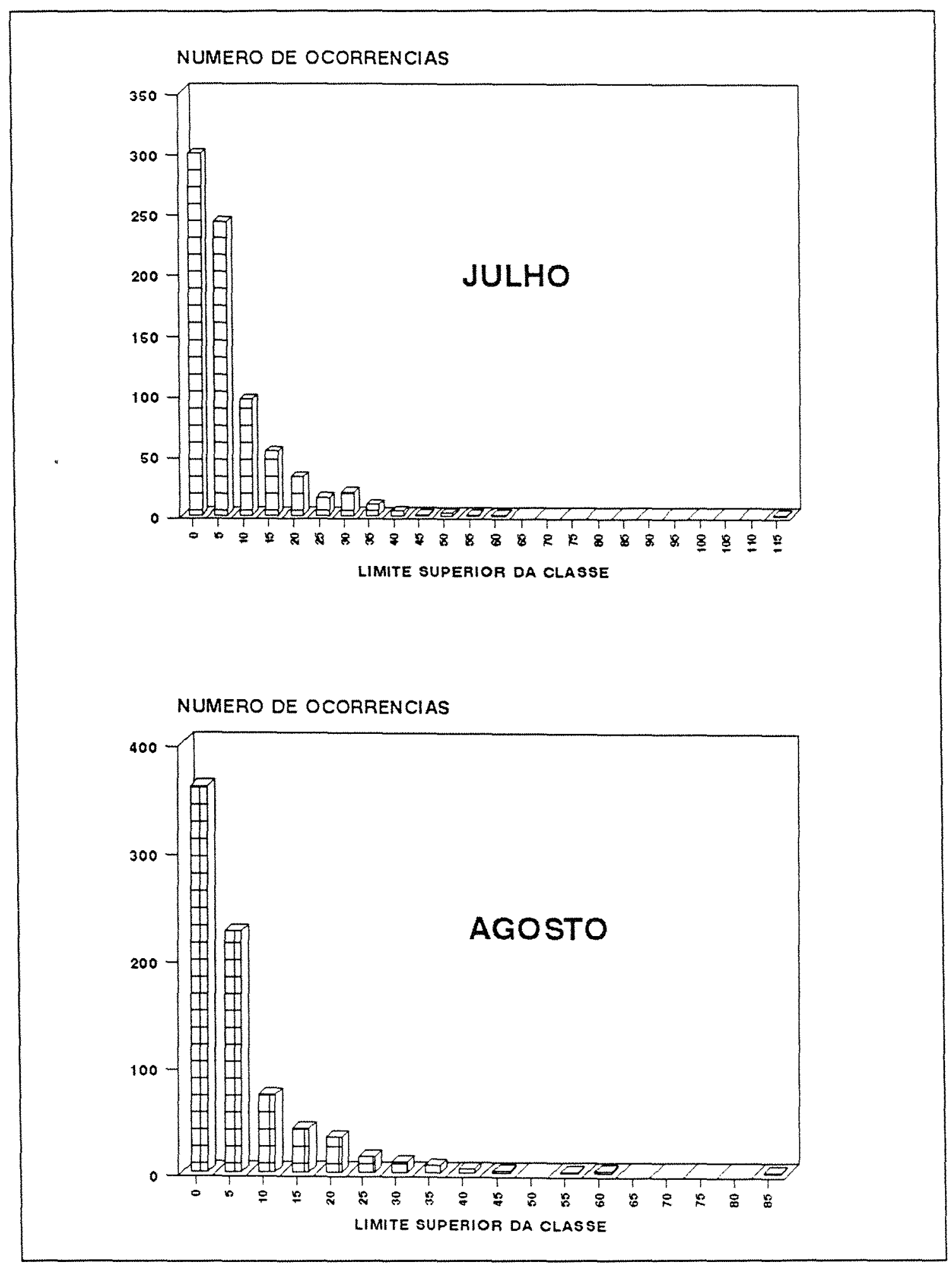

Figura 13 - Distribuição de frequência da intensidade de chuva no período 1967 a 1991 dos meses julho e agosto, sendo representada a frequencia de dias sem chuva (classe 0). Fonte de dados brutos: INMET. 


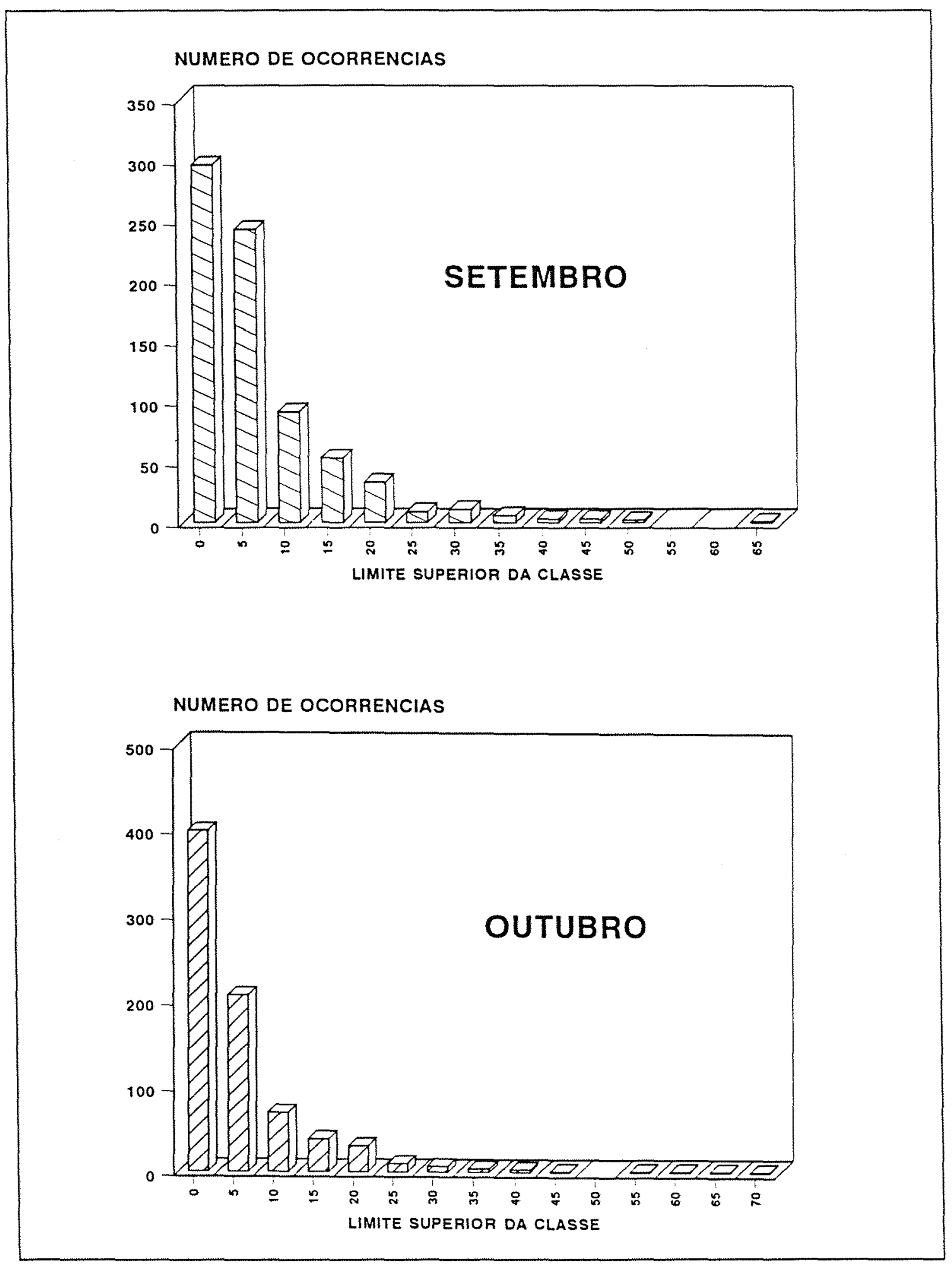

Figura 14 - Distribuição de frequência da intensidade de chuva no período 1967 a 1991 dos meses setembro e outubro, sendo representada a frequência de dias sem chuva (classe 0 ). Fonte de dados brutos: INMET. 


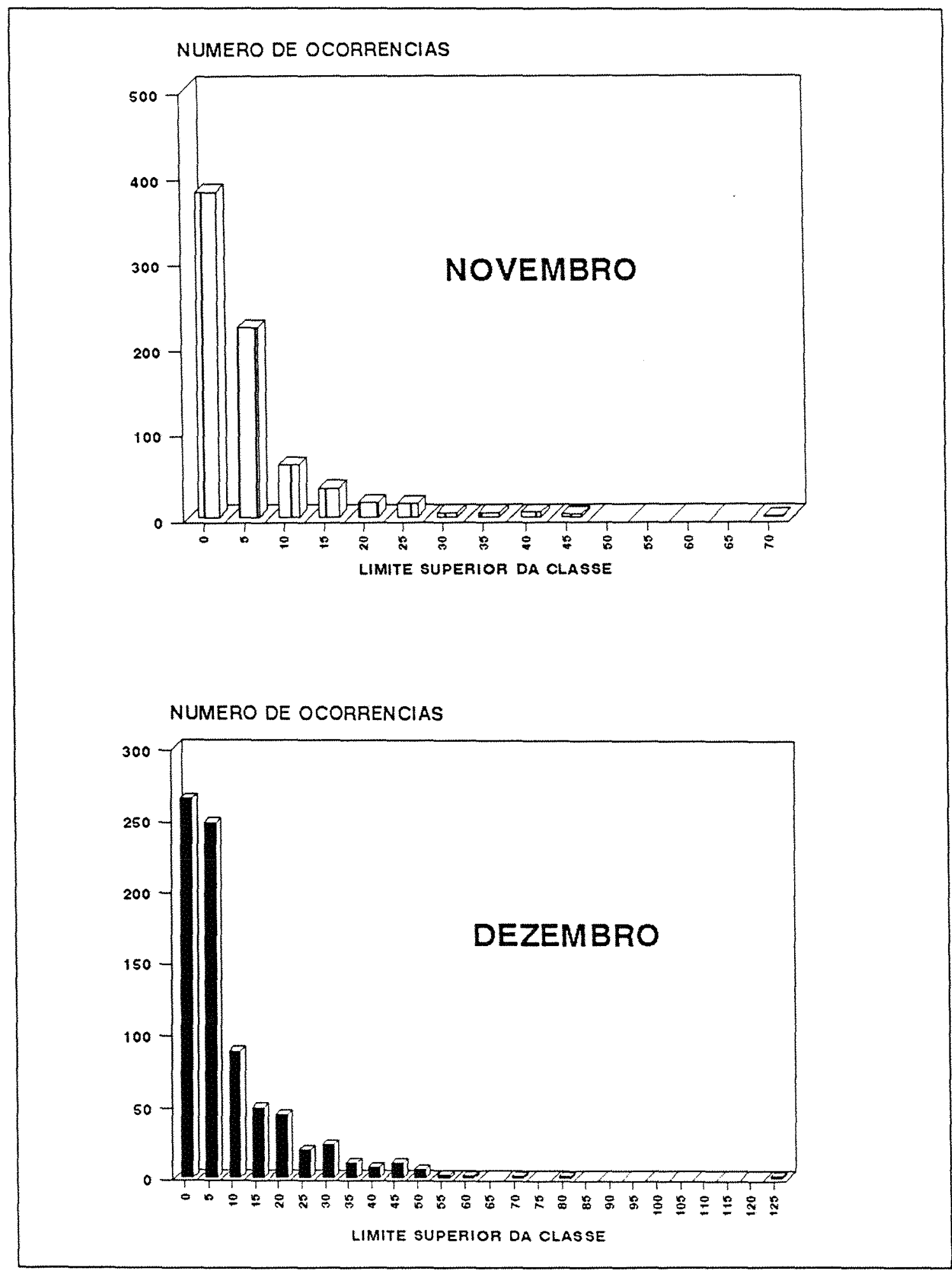

Figura 15 - Distribuição de frequência da intensidade de chuva no período 1967 a 1991 dos meses novembro e dezembro, sendo representada a frequência de dias sem chuva (classe 0 ). Fonte de dados brutos: INMET. 


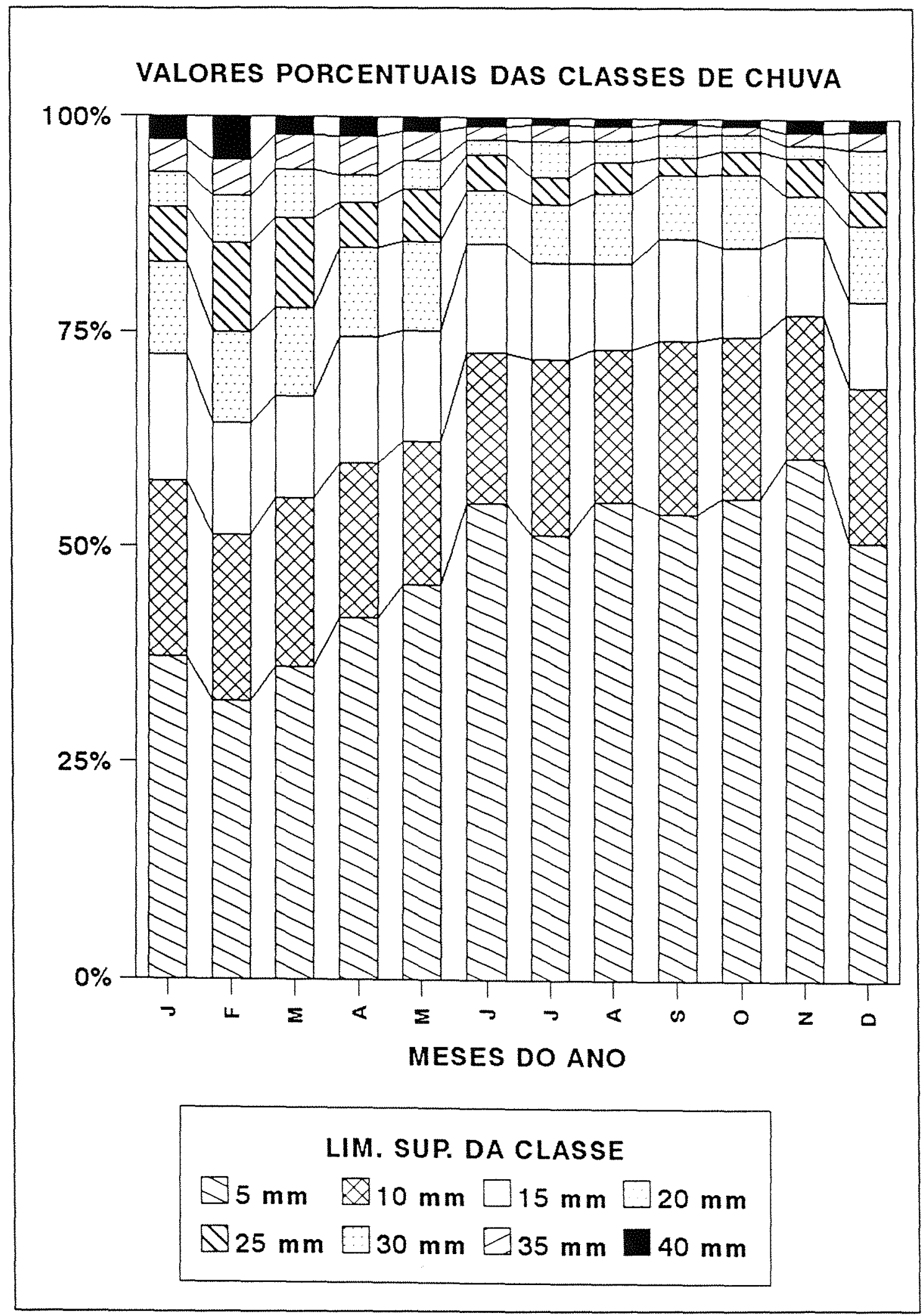

Figura 16 - Distribuição percentual da intensidade de chuva em Belém. 
Nos meses de junho, julho e agosto essa intensificação é ocasionada por ondas que se formam no campo de pressão atmosférica, ao longo dos alísios, na faixa tropical do globo, deslocando-se de leste para oeste?

$\mathrm{Na}$ maioria dos casos as chuvas em Belém são de origem convectiva com formação local cujo o desenvolvimento das células começa durante o período da manhã ou por linhas convectivas que formam-se no litoral, ou fora dele, devido à brisa e se deslocando para o continente, chegando a Belém à tarde, dissipando-se após o por do sol. Consequentemente, é no período da tarde que ocorre o maior percentual de chuva, esse fato pode ser comprovado nas figuras 17 a 28 . Observa-se que nos meses menos chuvosos $(0, N)$ - percentual no período da manhã é pequeno e a maior concentração de chuva ocorre realmente no período da tarde.

7 NECHET, D. (UNIVERSIDADE FEDERAL DO PARÁ. Departamento de Meteorologia). Comunicação pessoal, 1992. 


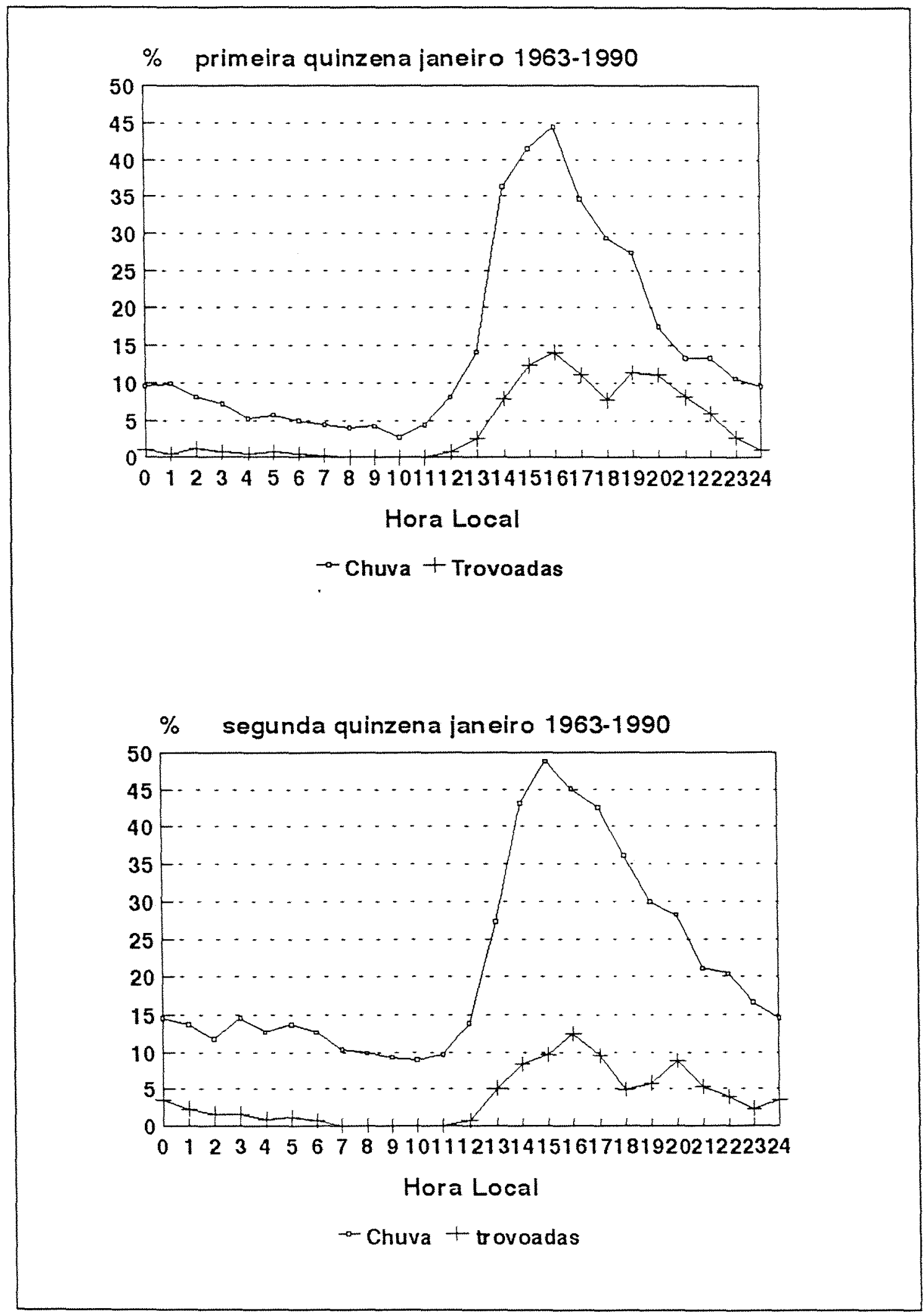

Figura 17 - Variabilidade diurna de chuva e trovoadas no mês de janeiro em Belém - PA. (NECHET, 1984). 


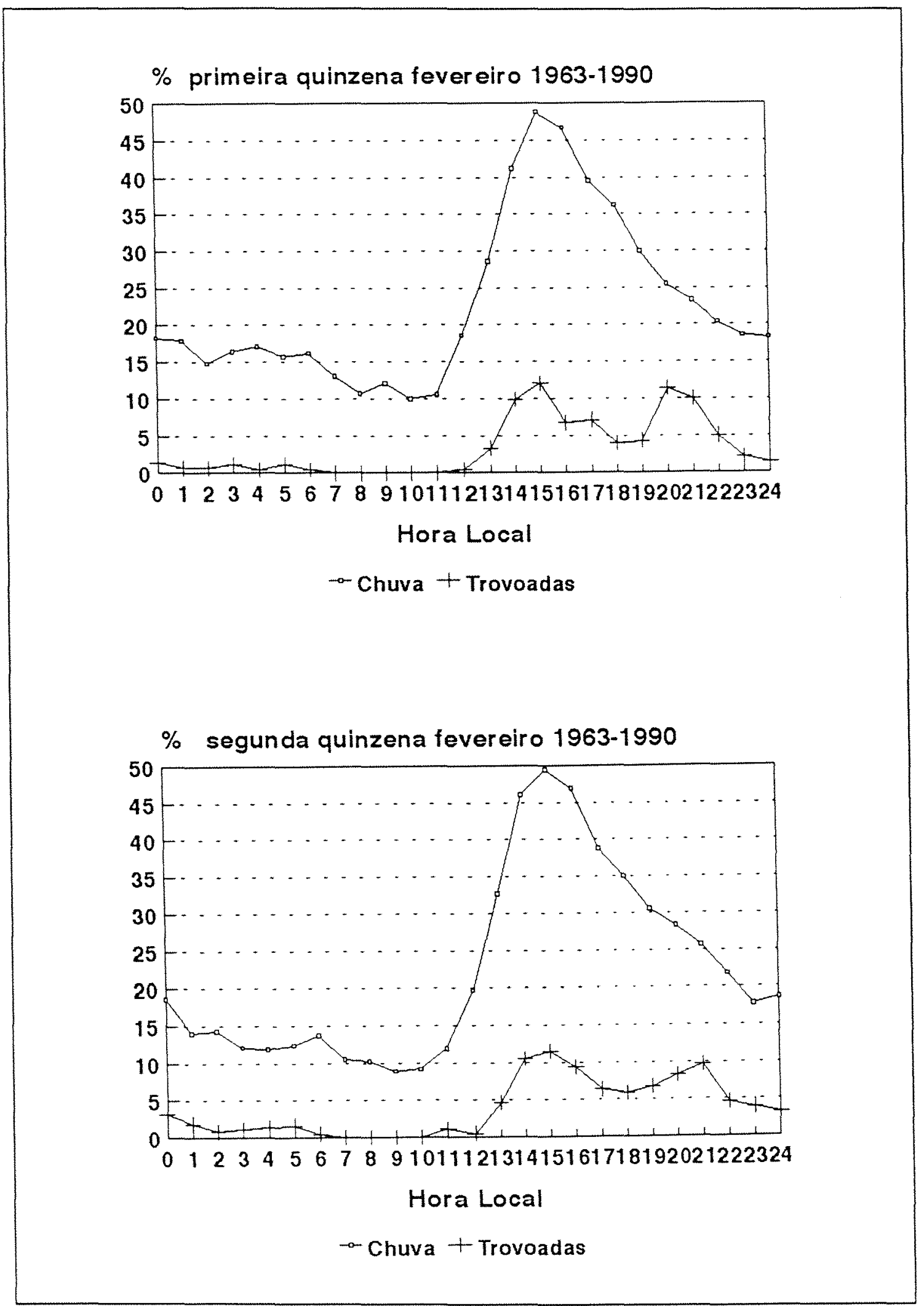

Figura 18 - Variabilidade diurna de chuva e trovoadas no mês de fevereiro em Belém - PA. (NECHET, 1984). 


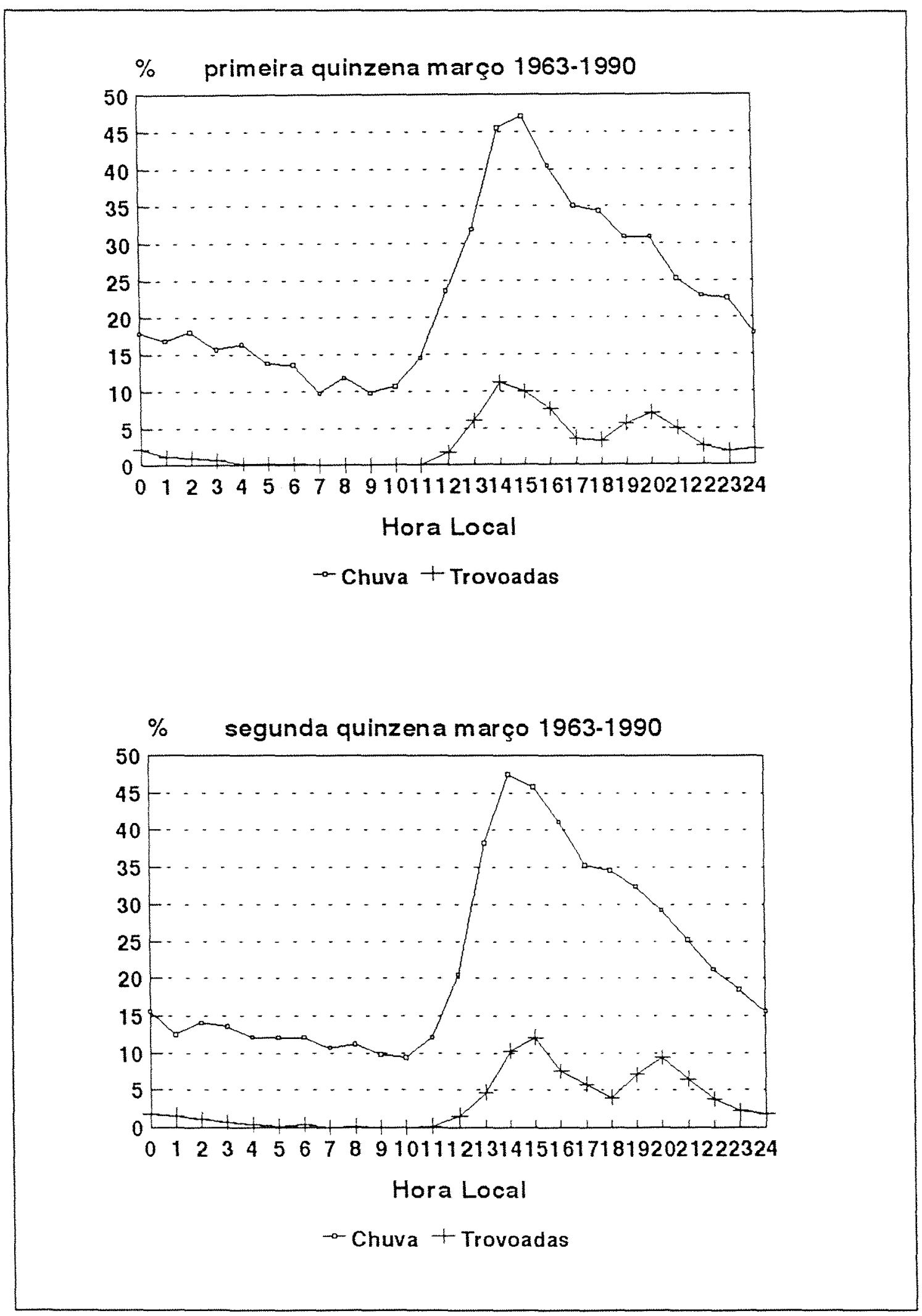

Figura 19 - Variabilidade diurna de chuva e trovoadas no mês de março em Belém - PA. (NECHET, 1984). 


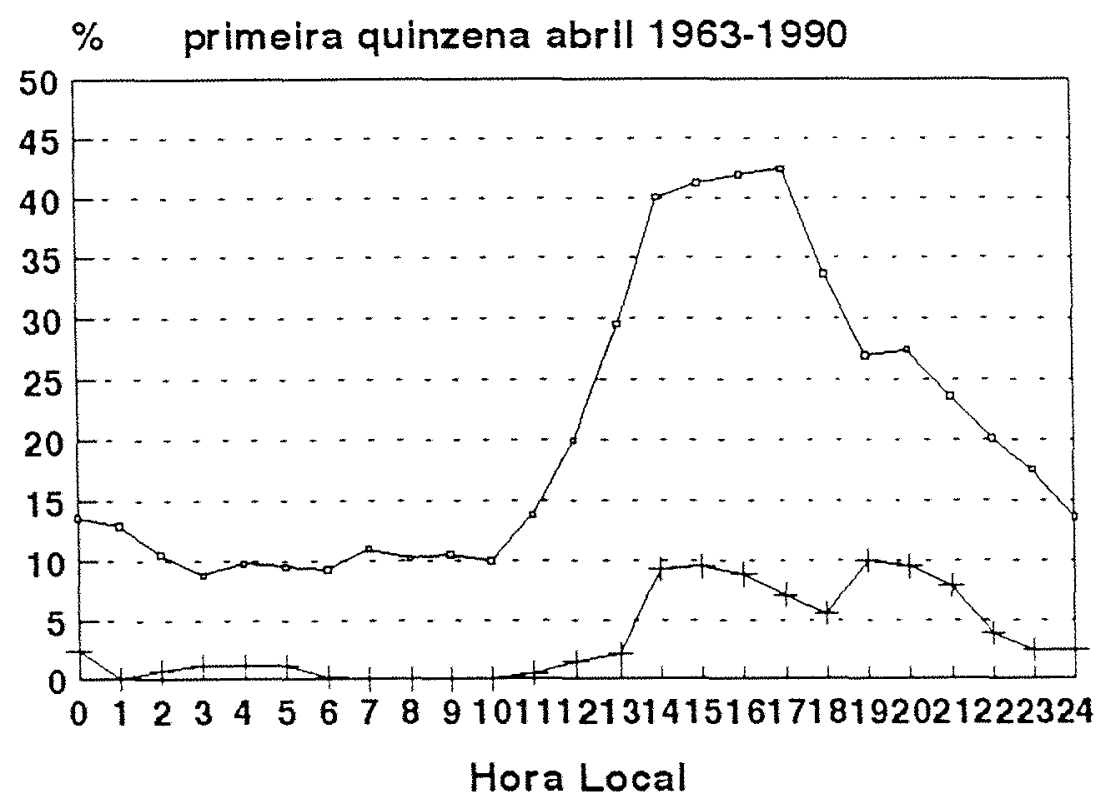

- Chuva + Trovoadas

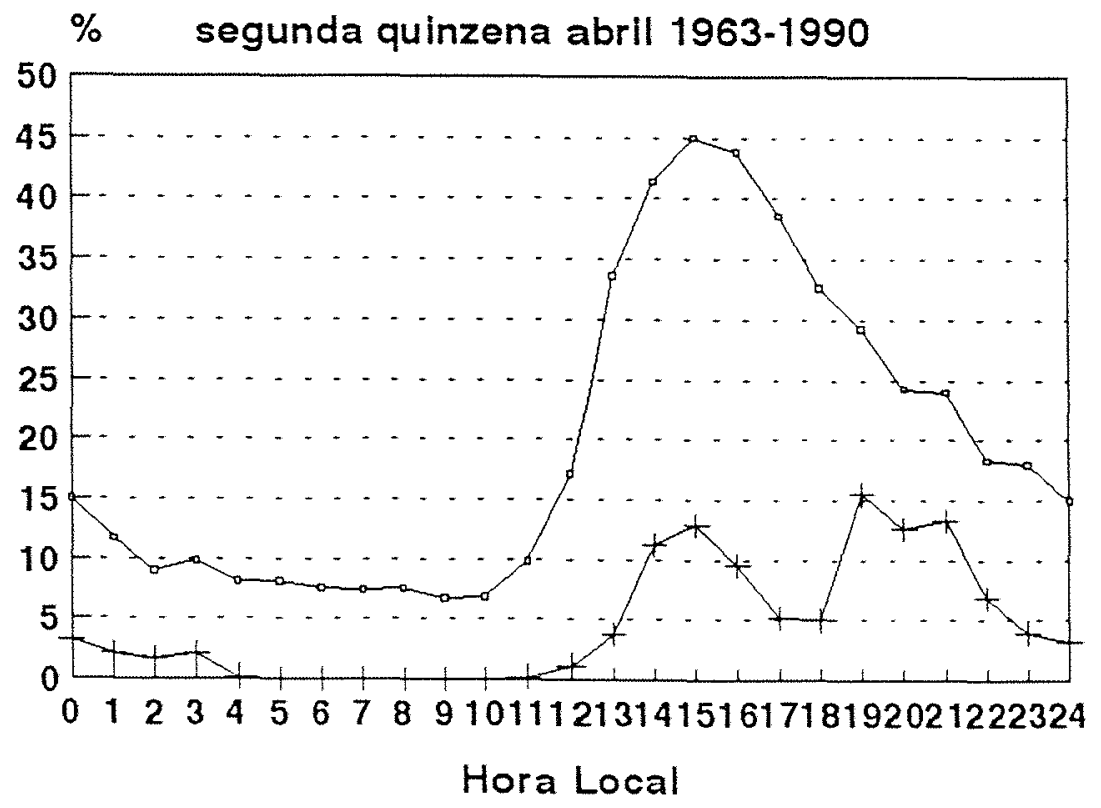

Chuva + Trovoadas

Figura 20 - Variabilidade diurna de chuva e trovoadas no mês de abril em Belém - PA. (NECHET, 1984). 


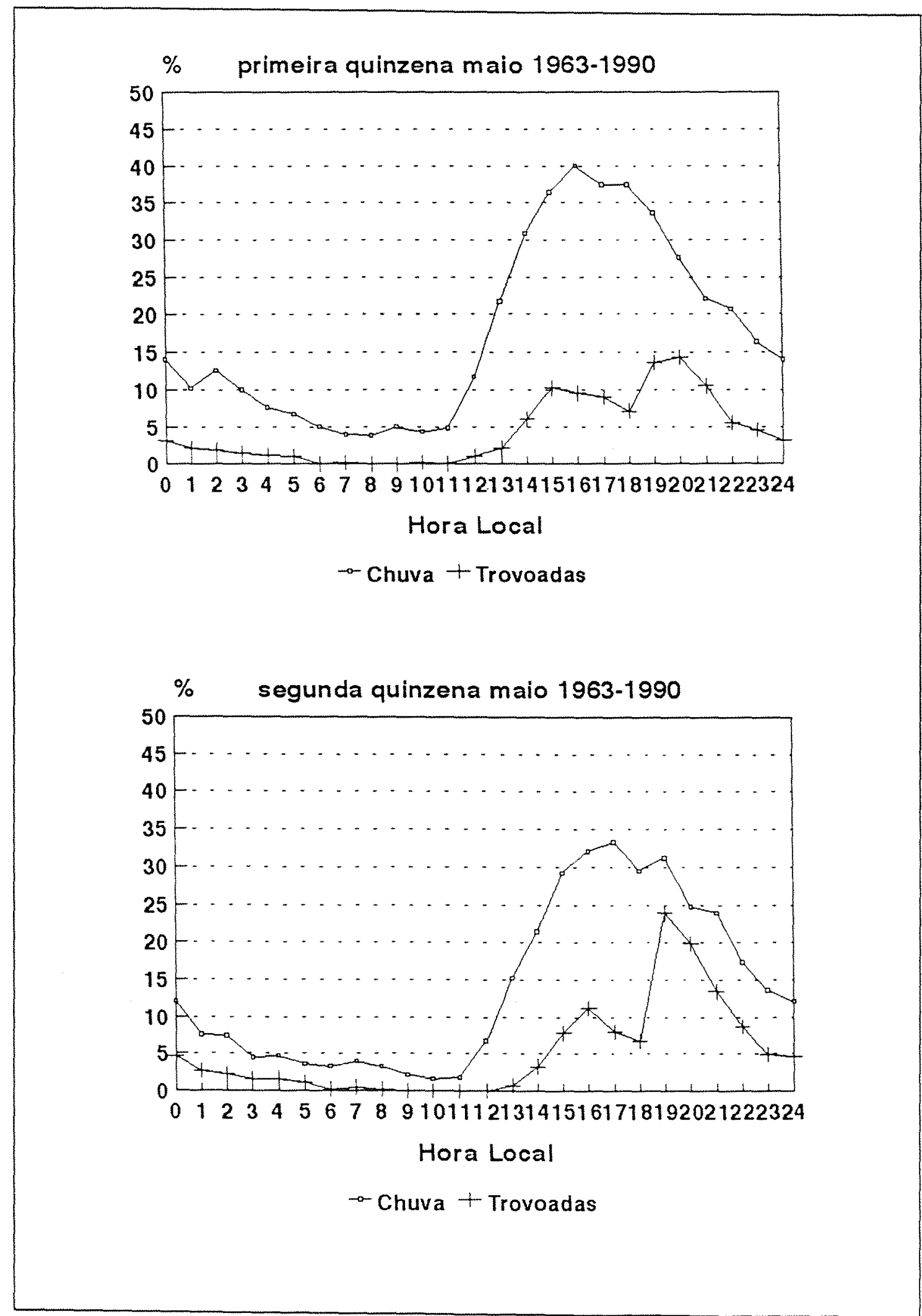

Figura 21 - Variabilidade diurna de chuva e trovoadas no mês de maio em Belém - PA. (NECHET, 1984). 

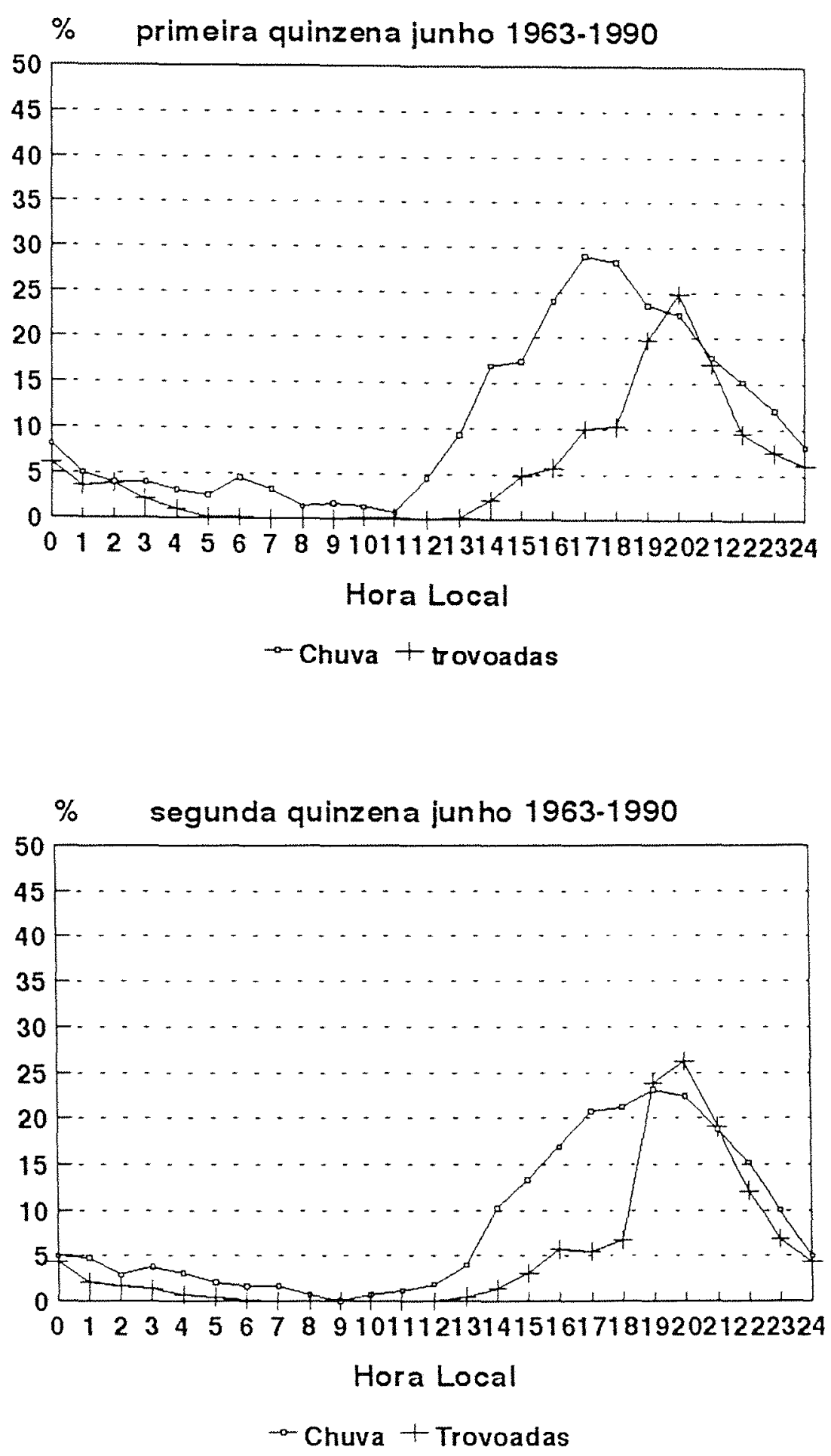

Figura 22 - Variabilidade diurna de chuva e trovoadas no mês de junho em Belém - PA. (NECHET, 1984). 


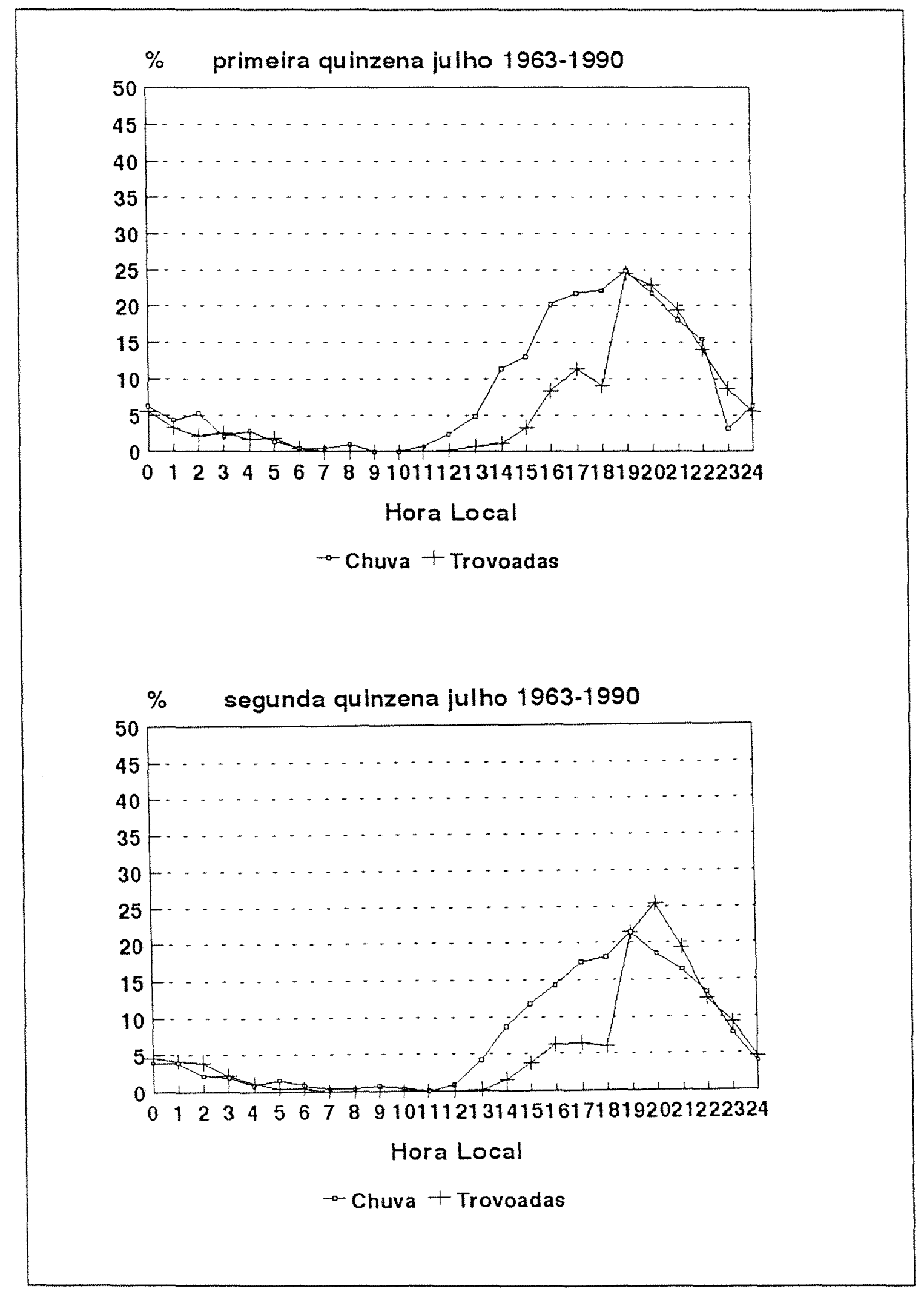

Figura 23 - Variabilidade diurna de chuva e trovoadas no mês de julho em Belém - PA. (NECHET, 1984). 

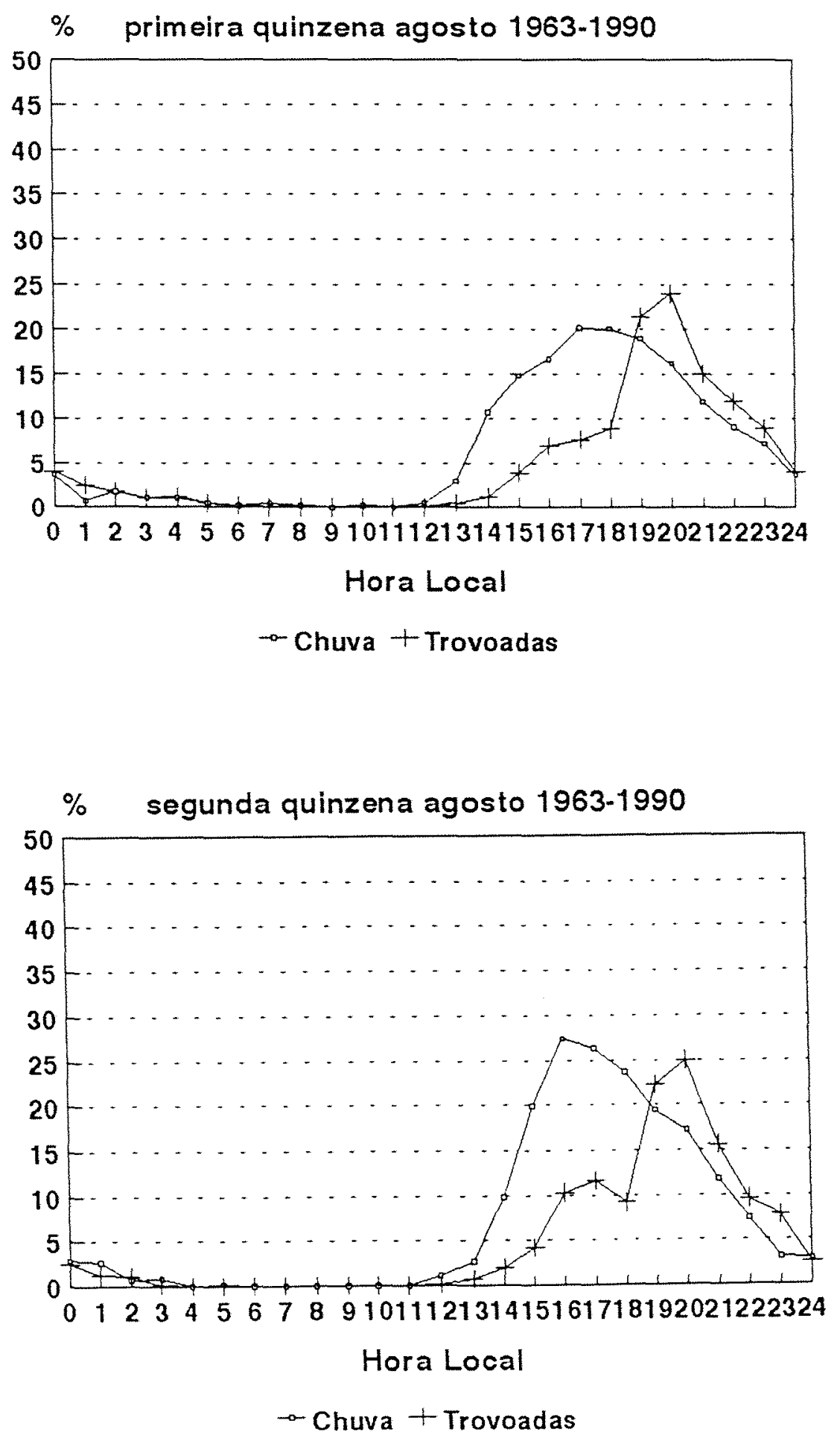

Figura 24 - Variabilidade diurna de chuva e trovoadas no mês de agosto em Belém - PA. (NECHET, 1984). 


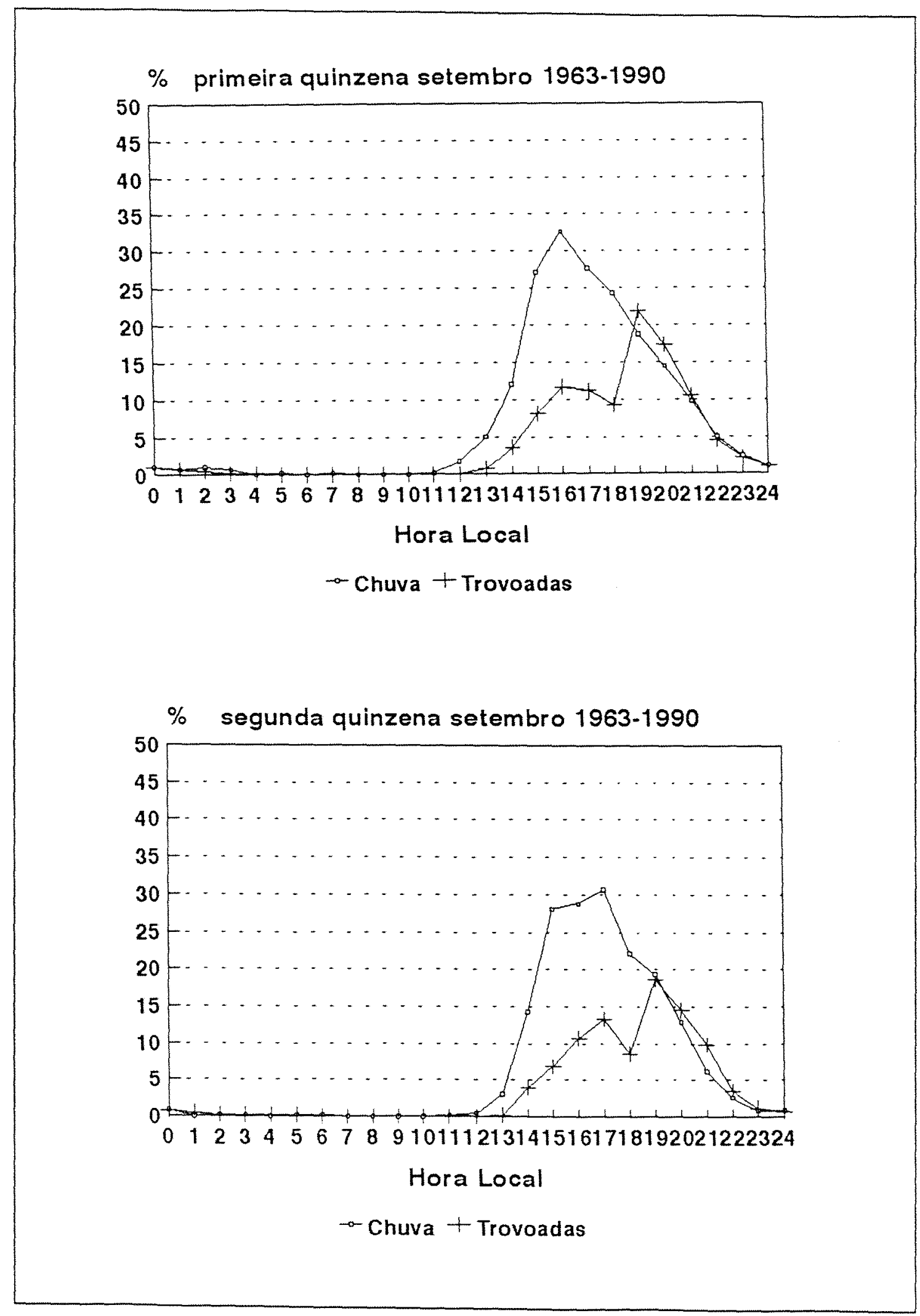

Figura 25 - Variabilidade diurna de chuva e trovoadas no mês de setembro em Belém - PA. (NECHET, 1984). 

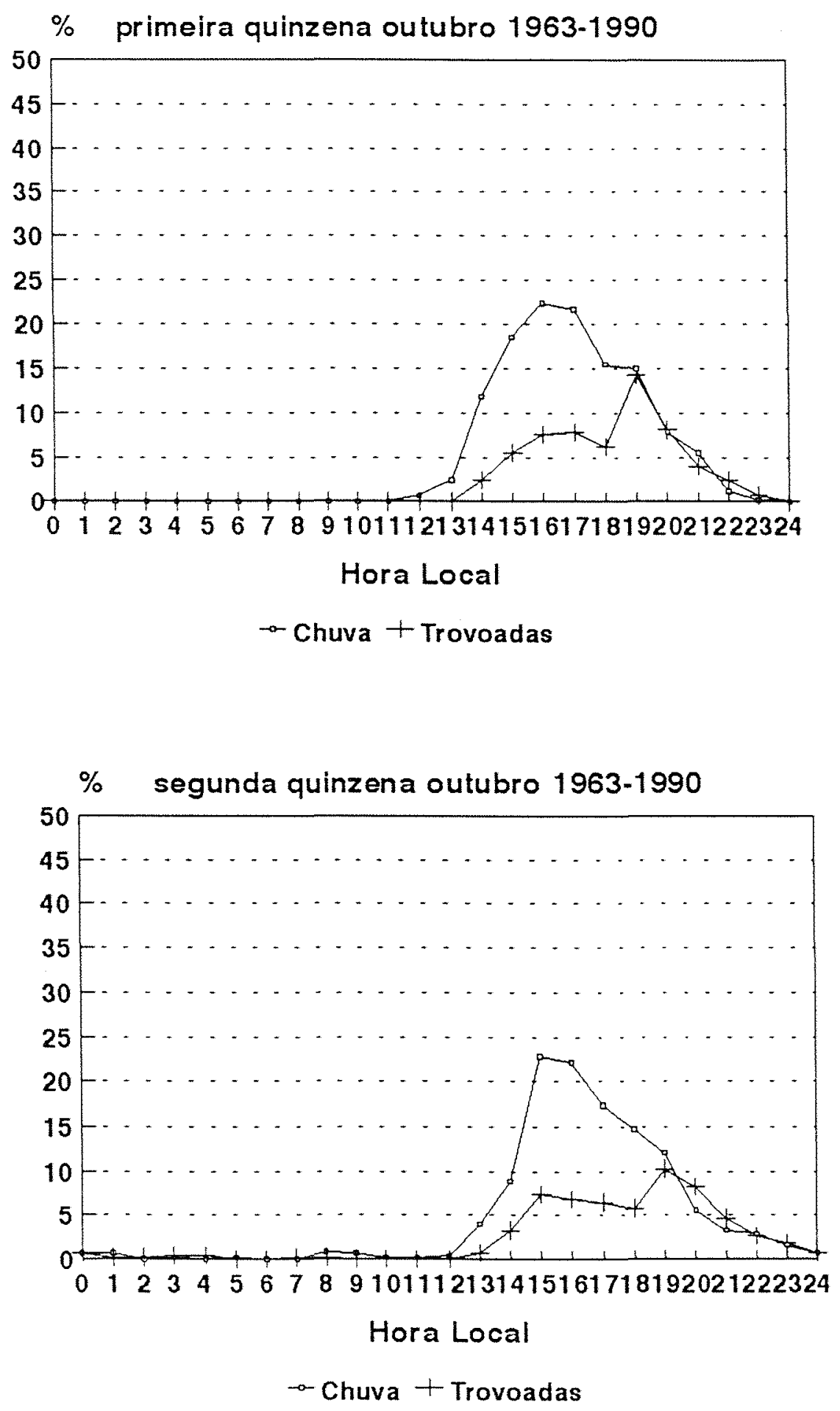

Figura 26 - Variabilidade diurna de chuva e trovoadas no mês de outubro em Belém - PA. (NECHET, 1984). 


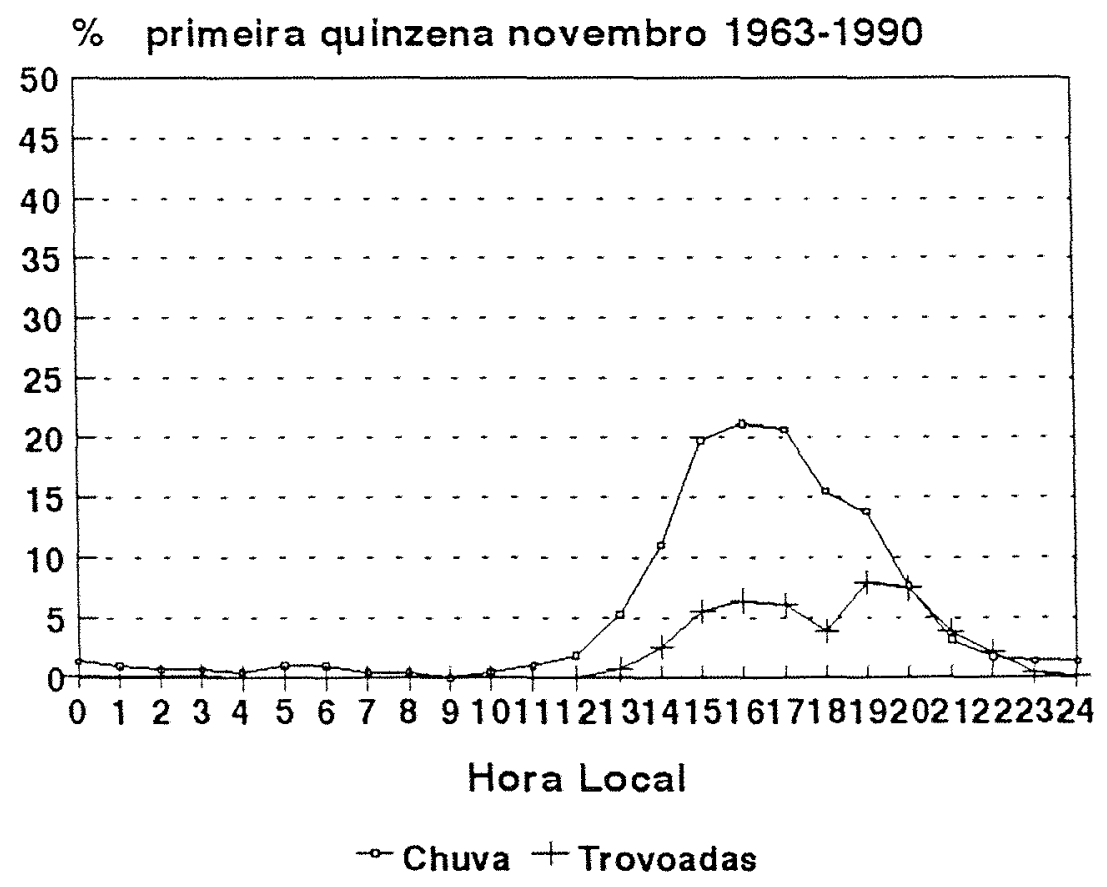

$\%$ segunda quinzena novembro 1963-1990

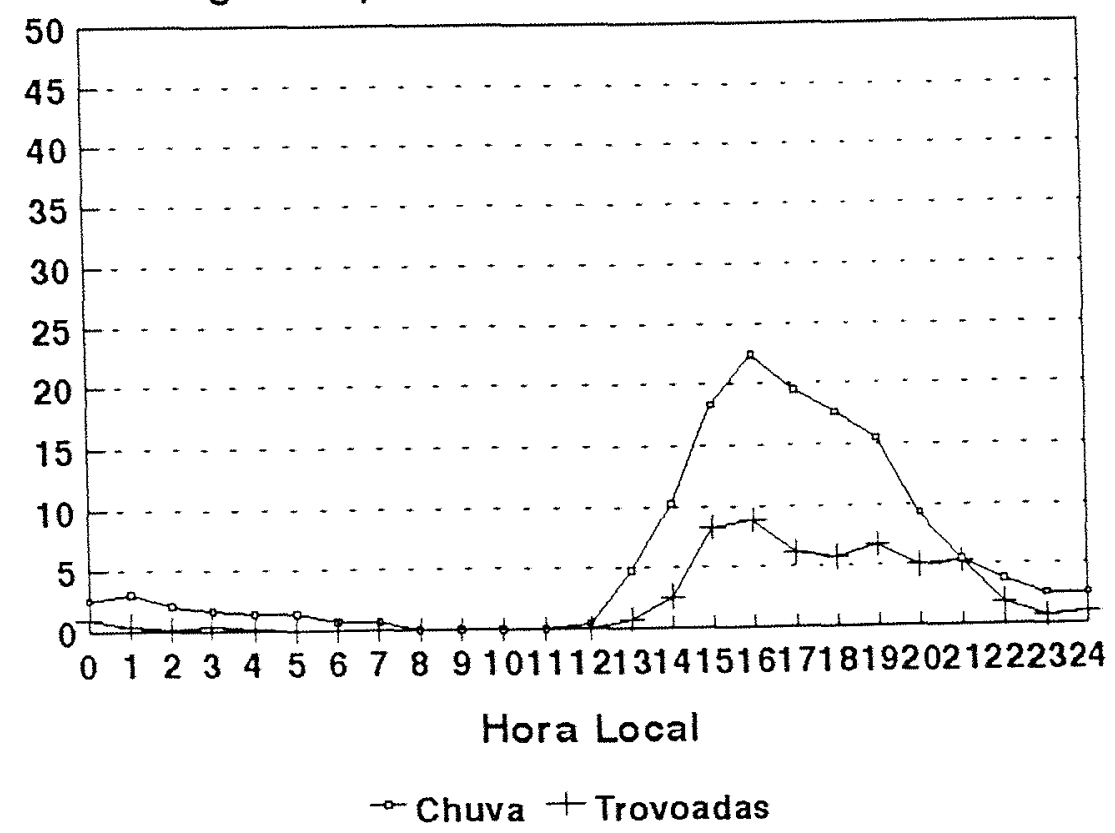

Figura 27 - Variabilidade diurna de chuva e trovoadas no mês de novembro em Belém - PA. (NECHET, 1984). 

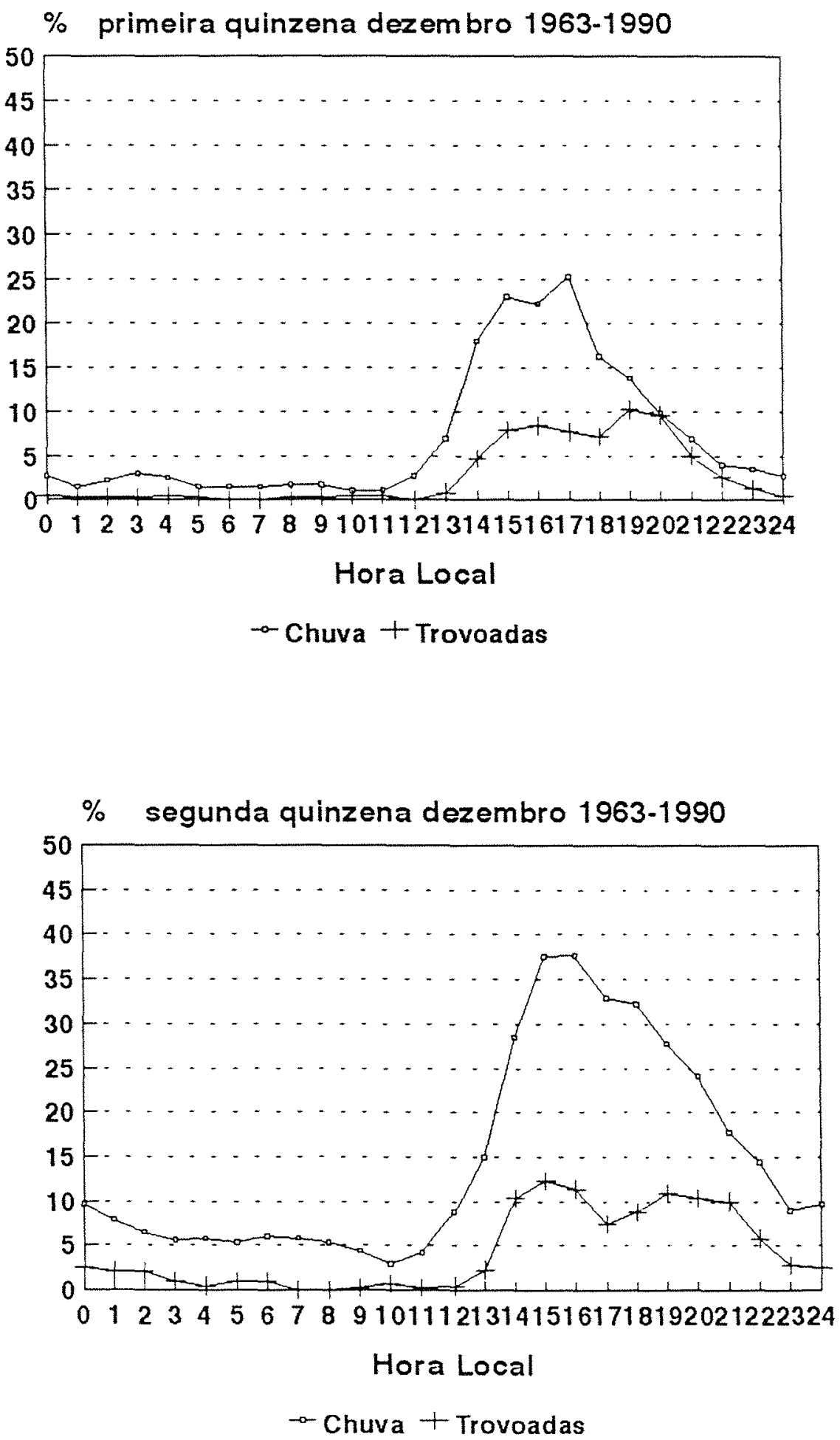

Figura 28 - Variabilidade diurna de chuva e trovoadas no mês de dezembro em Belém - PA. (NECHET, 1984). 


\subsection{Tendência secular}

Os valores quantitativos das tendências do total anual de chuva, da maior temperatura máxima absoluta do ano, da menor temperatura mínima absoluta do ano, da chuva mensal e das temperaturas absolutas extremas, para o período integral (1896 a 1991) e os três períodos distintos são mostrados nas tabelas 4 a 6 .

os valores positivos caracterizam tendências crescentes e os negativos tendências decrescentes.

Tabela 4 - Valores quantitativos de tendências de chuva em $\mathrm{mm}$.

\begin{tabular}{|l|r|r|r|r|}
\hline \multirow{2}{*}{ Meses } & \multicolumn{4}{|c|}{ Periodos } \\
\cline { 2 - 5 } & $1896-1930$ & $1931-1960$ & $1961-1991$ & $1896-1991$ \\
\hline JAN & 114,1 & 38,6 & 72,7 & 75,0 \\
FEV & 42,9 & $-63,9$ & 85,3 & 75,4 \\
MAR & 75,1 & $-34,2$ & 10,7 & 52,7 \\
ABR & 47,9 & 136,0 & 30,5 & 53,2 \\
MAI & 19,6 & $-108,5$ & $-65,0$ & 20,5 \\
JUN & $-2,0$ & 34,3 & 28,4 & $-18,8$ \\
JUL & $-36,4$ & 21,8 & 47,0 & $-15,7$ \\
AGO & 13,8 & $-15,3$ & 53,8 & 4,5 \\
SET & 42,7 & $-4,5$ & 6,2 & 51,8 \\
OUT & 6,1 & 2,2 & 27,4 & 53,9 \\
NOV & 37,2 & 30,7 & $-27,0$ & 51,8 \\
DEZ & 50,4 & 108,0 & 86,2 & 74,8 \\
\hline Total anual & & & & \\
da Chuva & 413,5 & 127,9 & 469,2 & 458,5 \\
\hline
\end{tabular}


Tabela 5 - Valores quantitativos de tendências da temperatura máxima absoluta em ${ }^{\circ} \mathrm{C}$.

\begin{tabular}{|c|c|c|c|c|}
\hline \multirow{2}{*}{ Meses } & \multicolumn{4}{|c|}{ Períodos } \\
\cline { 2 - 5 } & $1896-1930$ & $1931-1960$ & $1961-1991$ & $1896-1991$ \\
\hline JAN & 1,56 & $-0,28$ & $-0,53$ & 0,04 \\
FEV & 2,07 & 0,03 & $-0,15$ & 0,15 \\
MAR & 1,60 & $-0,71$ & $-0,15$ & 0,12 \\
ABR & 2,20 & $-0,13$ & $-0,73$ & $-0,02$ \\
MAI & 1,13 & $-0,15$ & $-0,07$ & $-0,08$ \\
JUN & 1,42 & 0,07 & $-0,42$ & 0,23 \\
JUL & 1,59 & 0,00 & $-1,26$ & 0,45 \\
AGO & 2,45 & $-0,29$ & $-0,98$ & 0,57 \\
SET & 2,17 & $-0,04$ & $-0,02$ & $-0,17$ \\
OUT & 2,73 & $-0,30$ & $-0,13$ & $-0,48$ \\
NOV & 2,42 & $-0,48$ & $-0,51$ & $-0,93$ \\
DEZ & 1,91 & 0,27 & $-0,32$ & $-0,41$ \\
\hline Temperatura & & & & $-0,50$ \\
máx. abs. & 2,50 & $-0,39$ & 0,20 & \\
do ano & & & & \\
\hline
\end{tabular}

Tabela 6 -Valores de tendências da temperatura mínima absoluta em ${ }^{\circ} \mathrm{C}$.

\begin{tabular}{|c|c|c|c|r|}
\hline \multirow{2}{*}{ Meses } & \multicolumn{4}{|c|}{ Períodos } \\
\cline { 2 - 5 } & $1896-1930$ & $1931-1960$ & $1961-1991$ & $1896-1991$ \\
\hline JAN & $-0,24$ & 0,49 & 0,25 & 0,02 \\
FEV & 0,16 & 0,20 & $-0,35$ & 0,23 \\
ABR & $-0,42$ & 0,59 & $-0,10$ & 0,15 \\
MAI & $-0,07$ & 0,19 & $-0,05$ & 0,03 \\
JUN & $-0,14$ & 0,62 & $-0,16$ & 0,12 \\
JUL & $-0,35$ & 0,95 & $-0,37$ & 0,22 \\
AGO & $-0,25$ & 0,67 & $-0,34$ & 0,20 \\
SET & $-0,29$ & 0,53 & $-0,84$ & $-0,01$ \\
OUT & 0,07 & 0,58 & $-0,40$ & 0,33 \\
NOV & 0,21 & 1,06 & $-0,35$ & 0,35 \\
DEZ & $-0,10$ & 0,65 & 0,07 & $-0,11$ \\
\hline Temperatura & 0,31 & $-0,96$ & $-0,14$ & 0,05 \\
mín. abs. & 0,38 & 1,05 & $-0,63$ & 0,36 \\
do ano & & & & \\
\hline
\end{tabular}




\subsubsection{Tendência Anual das chuvas e Temperaturas Extremas}

Em Belém, a tendência do total anual de chuva foi crescente em todos os períodos, sendo que o período de 1896 a 1991, sofreu uma elevação de $458,5 \mathrm{~mm}$, figura 29 A.

A tendência da temperatura máxima absoluta do ano é mostrada na figura $29 \mathrm{~B}$, observa-se um decréscimo no período de 1896 a 1991, ocorrendo uma alternância nos três períodos distintos, ou seja crescente no primeiro período (1896 a 1930), decrescente no segundo período (1931 a 1960), e crescente no terceiro período (1961 a 1991), sendo que o primeiro período apresenta elevação de $2,5{ }^{\circ} \mathrm{C}$.

A figura $29 \mathrm{C}$, mostra a tendência da temperatura mínima absoluta do ano. Observa-se uma pequena elevação no período de 1896 a 1991, sendo que o terceito periodo (1961 a 1991), apresenta um decréscimo de $0,63{ }^{\circ} \mathrm{C}$. A maior elevação ocorreu no segundo período (1931 a 1960), com valor de $1,05^{\circ} \mathrm{C}$.

\subsubsection{Tendência Mensal das Chuvas}

A análise dos valores das tendências de chuva mensal mostra uma similaridade entre o período de 1896 a 1991, e o primeiro período (1896 a 1930), em ambos os períodos, somente os meses de junho e julho apresentaram-se com tendência decrescente, sendo que, no primeiro período 
(1896 a 1930), o mês de junho apresentou um pequeno valor negativo de $2,0 \mathrm{~mm}$ (figura $35 \mathrm{~A}$ ), e o mês de julho um valor negativo de $36,4 \mathrm{~mm}$ (figura $36 \mathrm{~A}$ ). O restante dos meses apresentaram-se com tendências crescentes sendo que o mês de janeiro apresentou uma elevação correspondente ao valor positivo de $114,1 \mathrm{~mm}$, considerada a mais elevada dos meses (figura $30 \mathrm{~A}$ ).

No segundo período (1931 a 1960), os meses de janeiro, abril, junho, julho, outubro, novembro e dezembro apresentaram-se com tendência crescente na chuva mensal, sendo que nesse período o maior valor de tendência crescente foi de $136,0 \mathrm{~mm}$ no mês de abril (figura $33 \mathrm{~A}$ ). O mês de outubro apresentou uma pequena elevação correspondente ao valor positivo de $2,2 \mathrm{~mm}$ considerada a menor elevação do período (figura $39 \mathrm{~A}$ ). Os meses de fevereiro, março, maio, agosto e setembro apresentaram-se com tendência decrescente de chuva mensal, sendo que maio apresentou o maior valor negativo correspondente a $108,5 \mathrm{~mm}$ (figura $34 \mathrm{~A}$ ). Setembro comportou-se como 0 mês de menor valor negativo correspondente a $4,5 \mathrm{~mm}$ (figura 38 A).

No terceito período (1961 a 1991), somente maio e novembro apresentaram tendência decrescente de chuva mensal, o restante dos meses apresentaram elevação na chuva mensal. Nesse período, maio comportou-se como o mês de maior valor negativo correspondente a $65,0 \mathrm{~mm}$ (figura $34 \mathrm{~A}$ ). Dos meses que apresentaram tendência crescente de chuva, dezembro com o valor positivo de $86,2 \mathrm{~mm}$ apresentou-se como 
- mês de maior elevação de chuva mensal (figura 41 A).

\subsubsection{Tendência Mensal da Temperatura Máxima Absoluta}

A análise de tendência da temperatura máxima absoluta mensal no período de 1896 a 1991 , mostrou a ocorrência de um decréscimo nos meses de abril, maio, setembro, outubro, novembro e dezembro. Uma elevação em janeiro, fevereiro, março, junho, julho e agosto. Nesse período, o mês de novembro foi o maior valor negativo correspondente a $0,93{ }^{\circ} \mathrm{C}$ (figura 40 B). Abril apresentou 0 menor valor negativo correspondente a $0,02^{\circ} \mathrm{C}$ (figura $33 \mathrm{~B}$ ). Agosto apresentou o maior valor positivo correspondente a $0,57^{\circ} \mathrm{C}$ (figura 37 B) e janeiro o menor valor positivo correspondente a $0,04{ }^{\circ} \mathrm{C}$ (figura $30 \mathrm{~B}$ ).

No primeiro período (1896 a 1930), o qual coincide com o começo do século, observa-se que em todos os meses do ano ocorreu elevação na tendência da temperatura máxima absoluta mensal. Outro fato observado é que todas as tendências foram superiores a $1,0^{\circ} \mathrm{C}$. No entanto, torna-se necessário um estudo mais aprofundado para que possa ser verificado mais detalhadamente esse fato. Nesse período, outubro apresenta-se como o mês de maior valor positivo correspondente a $2,73{ }^{\circ} \mathrm{C}$ (figura 39 B), e maio o mês de menor valor positivo correspondente $1,13^{\circ} \mathrm{C}$ (figura $34 \mathrm{~B}$ ). 
No segundo período (1931 a 1960), somente os meses de fevereiro, junho e dezembro apresentaram tendências crescentes, sendo que dezembro apresentou o maior valor positivo correspondente a $0,27^{\circ} \mathrm{C}$ (figura $41 \mathrm{~B}$ ), e fevereiro - mês de menor valor positivo correspondente a $0,03{ }^{\circ} \mathrm{C}$ (figura 31 B). Nesse período, observou-se que junho não sofreu nenhuma oscilação de tendência, portanto o valor foi nulo (figura 35 B). Os meses de janeiro, março, abril, maio, agosto, setembro, outubro e novembro apresentaram tendências decrescentes na temperatura máxima absoluta mensal, sendo que novembro apresentou o maior valor negativo correspondente a $0,48^{\circ} \mathrm{C}$ (figura $40 \mathrm{~B}$ ), e setembro o mês de menor valor negativo correspondente a $0,04{ }^{\circ} \mathrm{C}$ (figura $38 \mathrm{~B}$ ). No terceiro período (1961 a 1991), observou-se que todos os meses do ano apresentaram-se com tendências decrescente. No entanto, apesar de apresentarem todos os valores negativos, somente julho, considerado o mês de maior tendência decrescente do período, ultrapassou ao valor de $1,0{ }^{\circ} \mathrm{C}$ negativo (figura $36 \mathrm{~B}$ ). Setembro apresenta-se como 0 mês de menor valor negativo correspondente a $0,02{ }^{\circ} \mathrm{C}$ (figura 38 B) .

\subsubsection{Tendência Mensal da Temperatura Mínima Absoluta}

A análise de tendência da temperatura mínima absoluta mensal no período de 1896 a 1991, mostrou a 
ocorrência de um decréscimo nos meses de agosto e novembro. Agosto apresentou um valor negativo correspondente a $0,01{ }^{\circ} \mathrm{C}$ (figura $37 \mathrm{C}$ ), e novembro um valor negativo de $0,11{ }^{\circ} \mathrm{C}$ (figura $40 \mathrm{C}$ ). Os demais meses apresentaram-se com tendência crescente, sendo que outubro apresentou-se como o mês de maior valor positivo correspondente a $0,35^{\circ} \mathrm{C}$ (figura $39 \mathrm{C}$ ), e janeiro o menor valor positivo correspondente a $0,02{ }^{\circ} \mathrm{C}$ (figura $30 \mathrm{C}$ ).

No primeiro período (1896 a 1930), observou-se que os meses de janeiro, março, abril, maio, junho, julho, agosto e novembro apresentaram-se com tendência decrescente, sendo que março apresentou o maior valor negativo correspondente a $0,42{ }^{\circ} \mathrm{C}$ (figura $32 \mathrm{C}$ ), e abril o menor valor negativo correspondente a $0,07{ }^{\circ} \mathrm{C}$ (figura $33 \mathrm{C}$ ). Nesse período, os meses de fevereiro, setembro, outubro e dezembro apresentaram-se com tendência crescente, sendo que dezembro apresentou-se como o mês de maior valor positivo correspondente a $0,31{ }^{\circ} \mathrm{C}$ (figura $41 \mathrm{C}$ ), e setembro o menor valor positivo correspondente a $0,07^{\circ} \mathrm{C}$ (figura $38 \mathrm{C}$ ).

No segundo período, a análise da tendência da temperatura mínima absoluta mensal mostrou que somente o mês de dezembro apresentou-se com tendência decrescente correspondente ao valor negativo de $0,96{ }^{\circ} \mathrm{C}$ (figura $41 \mathrm{C}$ ). Nesse período, os demais meses apresentaram-se com tendência crescente, sendo que outubro, apresentou-se como o mês de maior valor positivo correspondente a $1,06{ }^{\circ} \mathrm{C}$ (figura $39 \mathrm{C}$ ), 
e abril o menor valor positivo correspondente a $0,19{ }^{\circ} \mathrm{C}$ (figura 33 C).

No terceiro período (1961 a 1991), somente os meses de janeiro e novembro apresentaram tendências da temperatura mínima absoluta mensal crescente, sendo que janeiro apresentou um valor positivo correspondente a $0,25{ }^{\circ} \mathrm{C}$ (figura $30 \mathrm{C}$ ), e novembro um valor positivo correspondente a $0,07{ }^{\circ} \mathrm{C}$ (figura $40 \mathrm{C}$ ). Os demais meses comportaram-se com tendência decrescente, sendo que o maior valor negativo foi de $0,84{ }^{\circ} \mathrm{C}$ em agosto (figura $37 \mathrm{C}$ ), e o menor valor negativo foi de $0,05^{\circ} \mathrm{C}$ em abril (figura $33 \mathrm{C}$ ). 


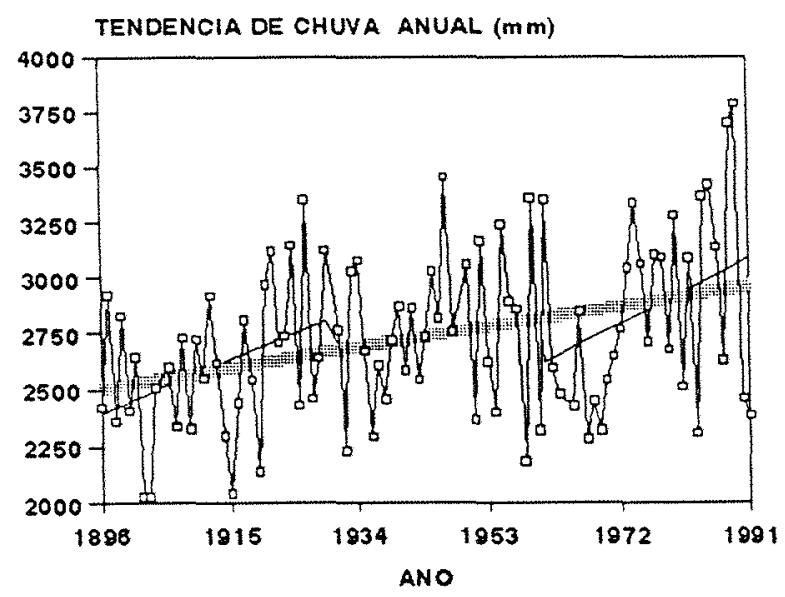

(A)

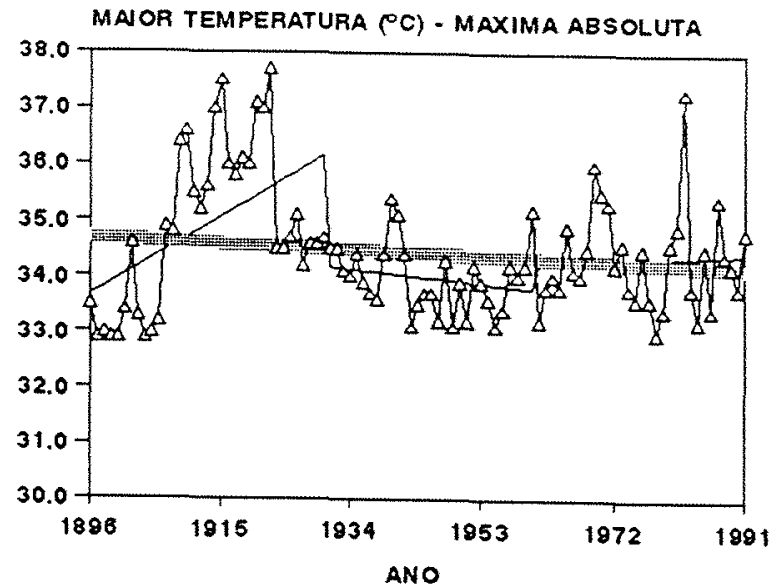

(B)

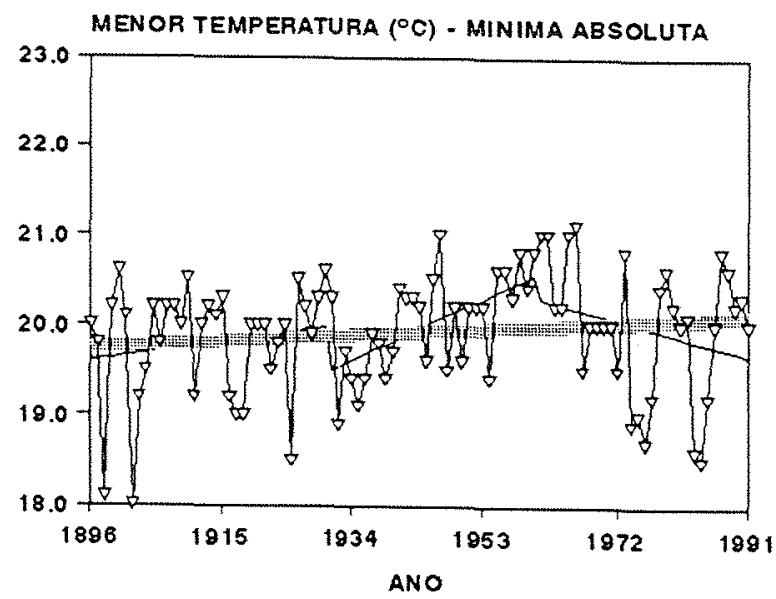

(C)

Figura 29 - Variação do total anual de chuva (a), variação da temperatura máxima absoluta do ano (b), variação da temperatura mínima absoluta do ano (c), períodos: $(1896-1991),(1896-1930)$, $(1931-1960),(1961-1991)$. Fonte dos dados brutos: INMET. 


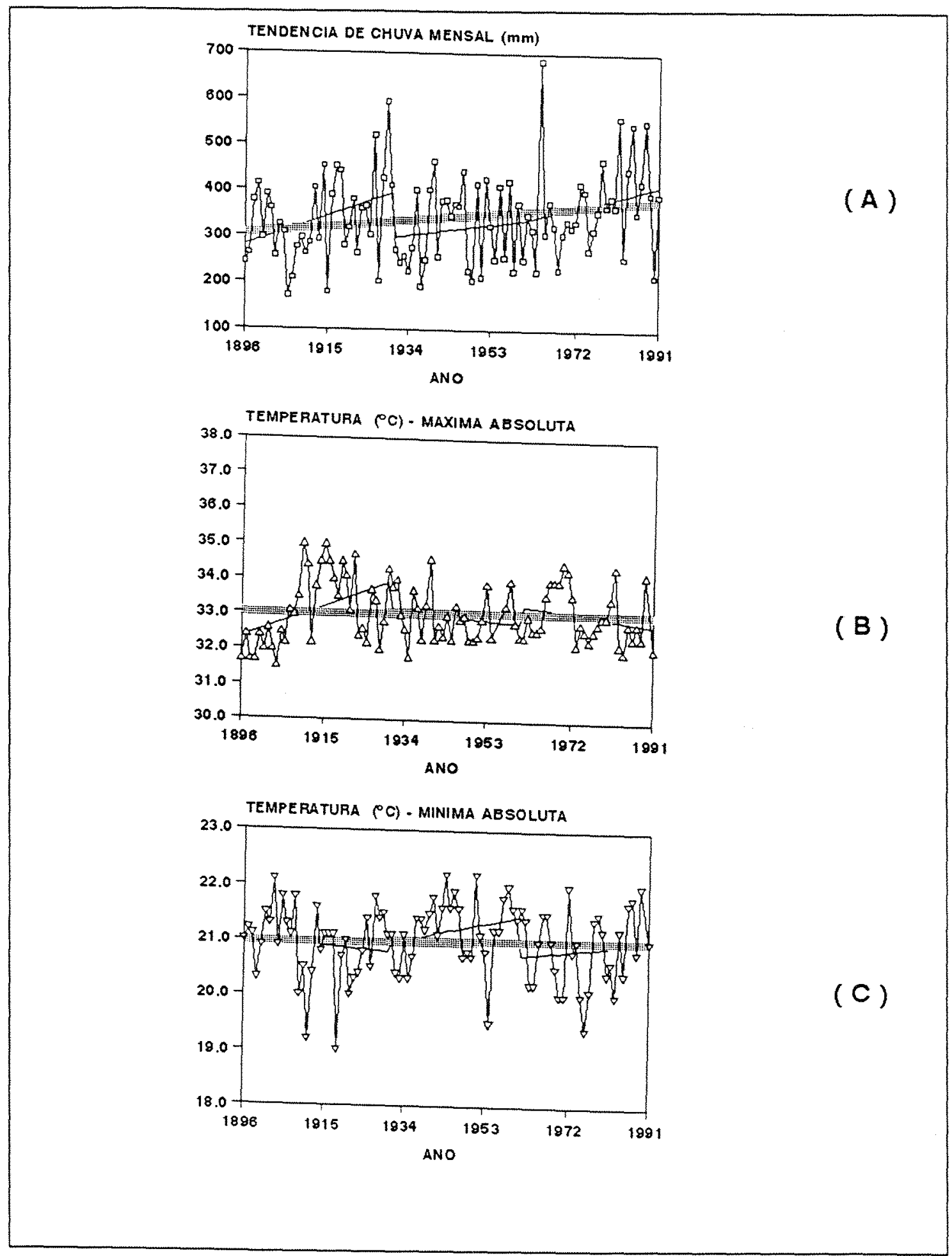

Figura 30 - Variação do total de chuva do mês de janeiro (a), variação da temperatura máxima absoluta no mês de janeiro (b), variação da temperatura mínima absoluta no mês de janeiro (c), períodos: $(1896-1991),(1896-1930), \quad(1931-1960)$, $(1961$ - 1991). Fonte dos dados brutos: INMET. 


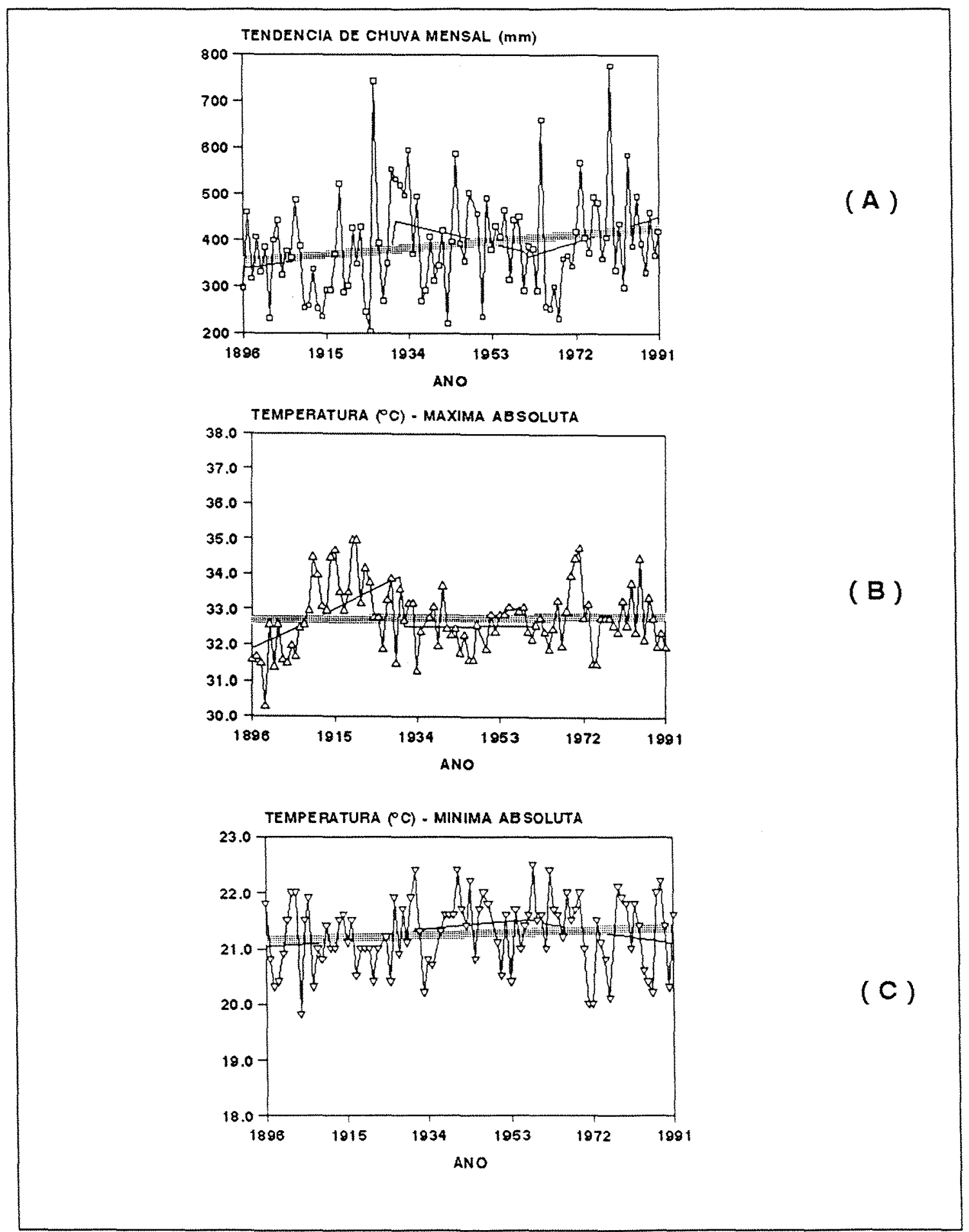

Figura 31 - Variação do total de chuva do mês de fevereiro (a), variação da temperatura máxima absoluta no mês de fevereiro (b), variação da temperatura mínima absoluta no mês de fevereiro (c), periodos: $\quad(1896-1991), \quad(1896-1930)$, $(1931$ - 1960), (1961 - 1991). Fonte dos dados brutos: INMET. 


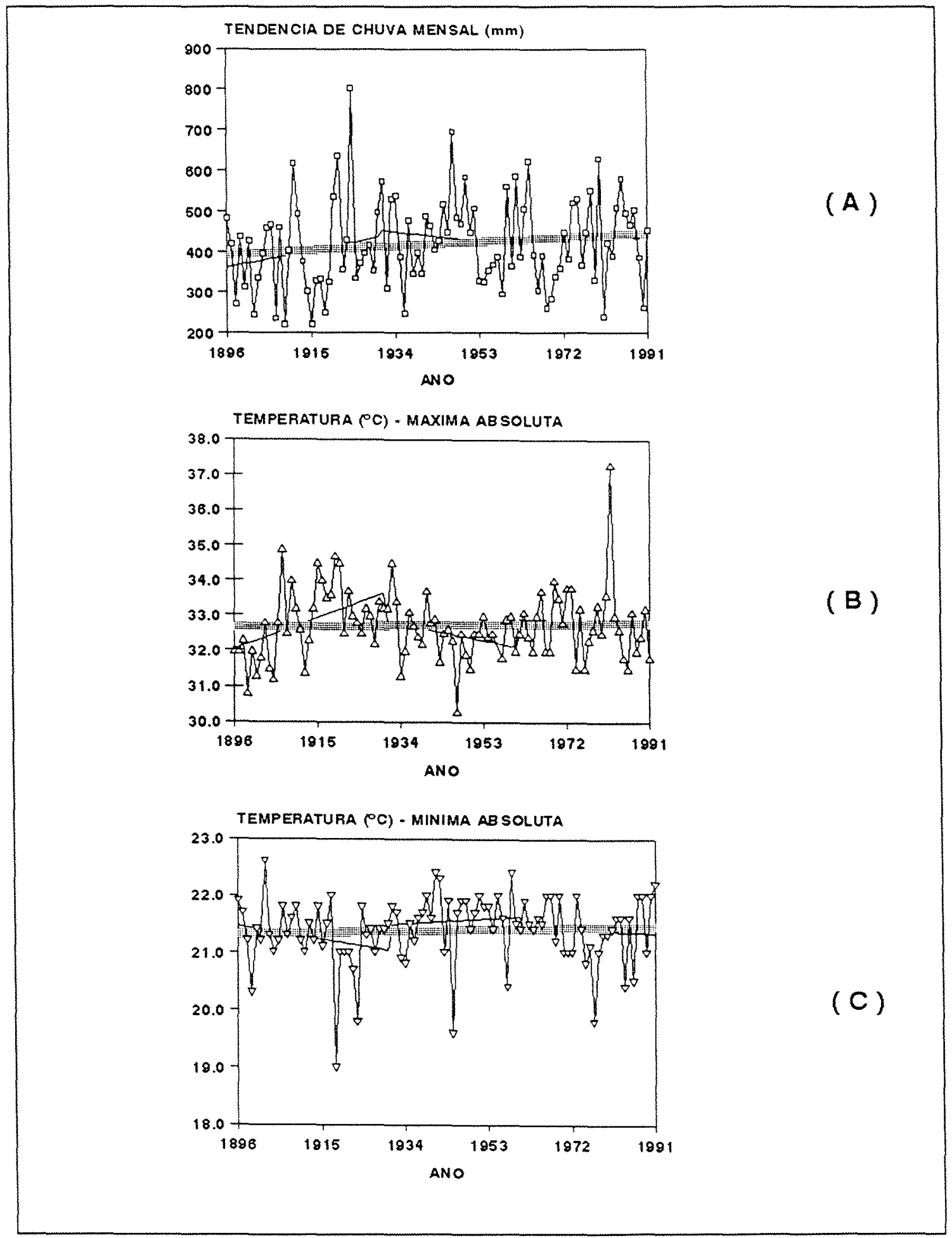

Figura 32 - Variação do total de chuva do mês de março (a), variação da temperatura máxima absoluta no mês de março (b), variação da temperatura mínima absoluta no mês de março (c), períodos: $(1896-1991),(1896-1930), \quad(1931-1960)$, $(1961$ - 1991). Fonte dos dados brutos: INMET. 


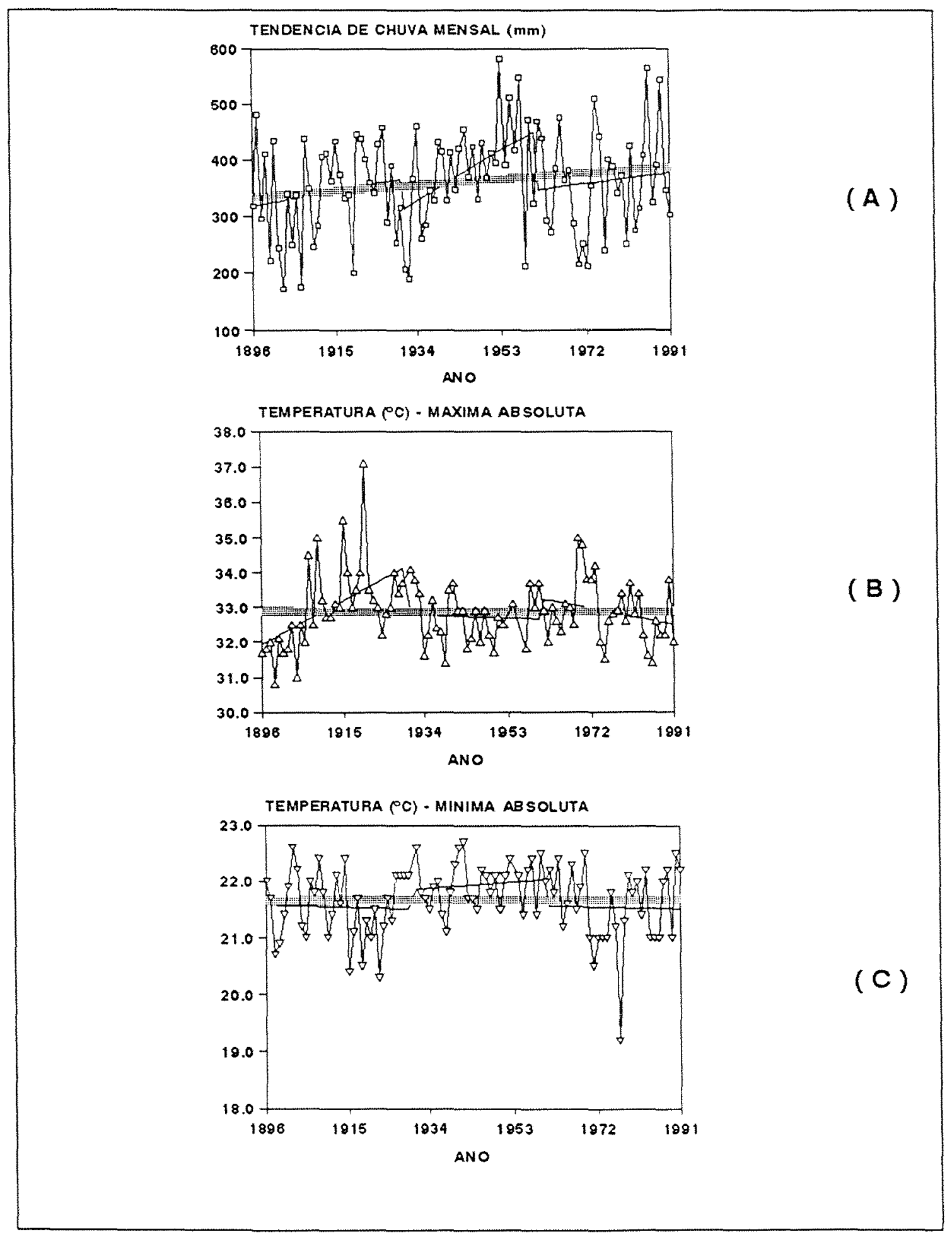

Figura 33 - Variação do total de chuva do mês de abril (a), variação da temperatura máxima absoluta no mês de abril (b), variação da temperatura mínima absoluta no mês de abril (c), períodos: $(1896-1991),(1896-1930),(1931-1960)$, $(1961$ - 1991). Fonte dos dados brutos: INMET. 


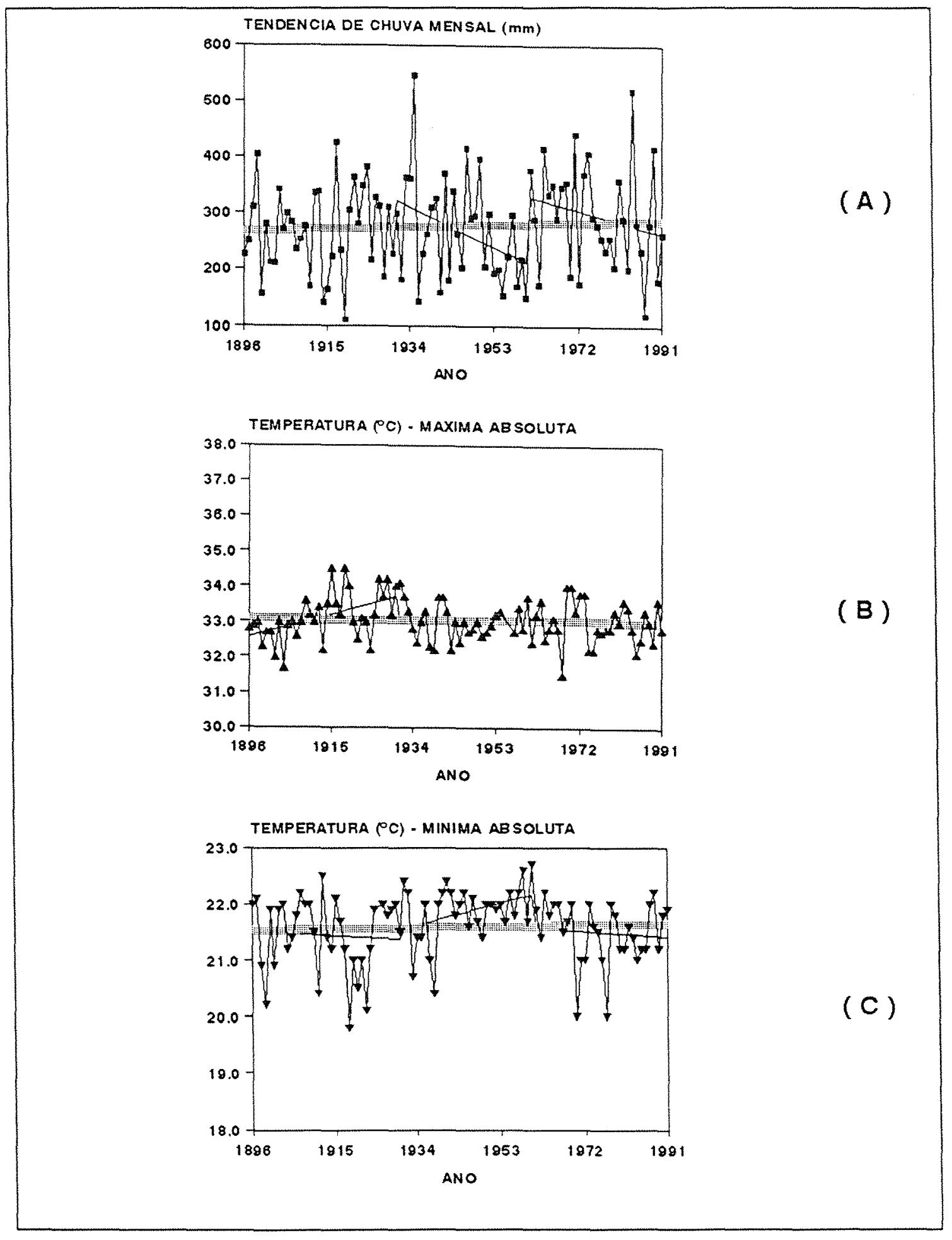

Figura 34 - Variação do total de chuva do mês de maio (a), variação da temperatura máxima absoluta no mês de maio (b), variação da temperatura mínima absoluta no mês de maio (c), periodos: $(1896-1991),(1896-1930),(1931-1960)$, (1961 - 1991). Fonte dos dados brutos: INMET. 


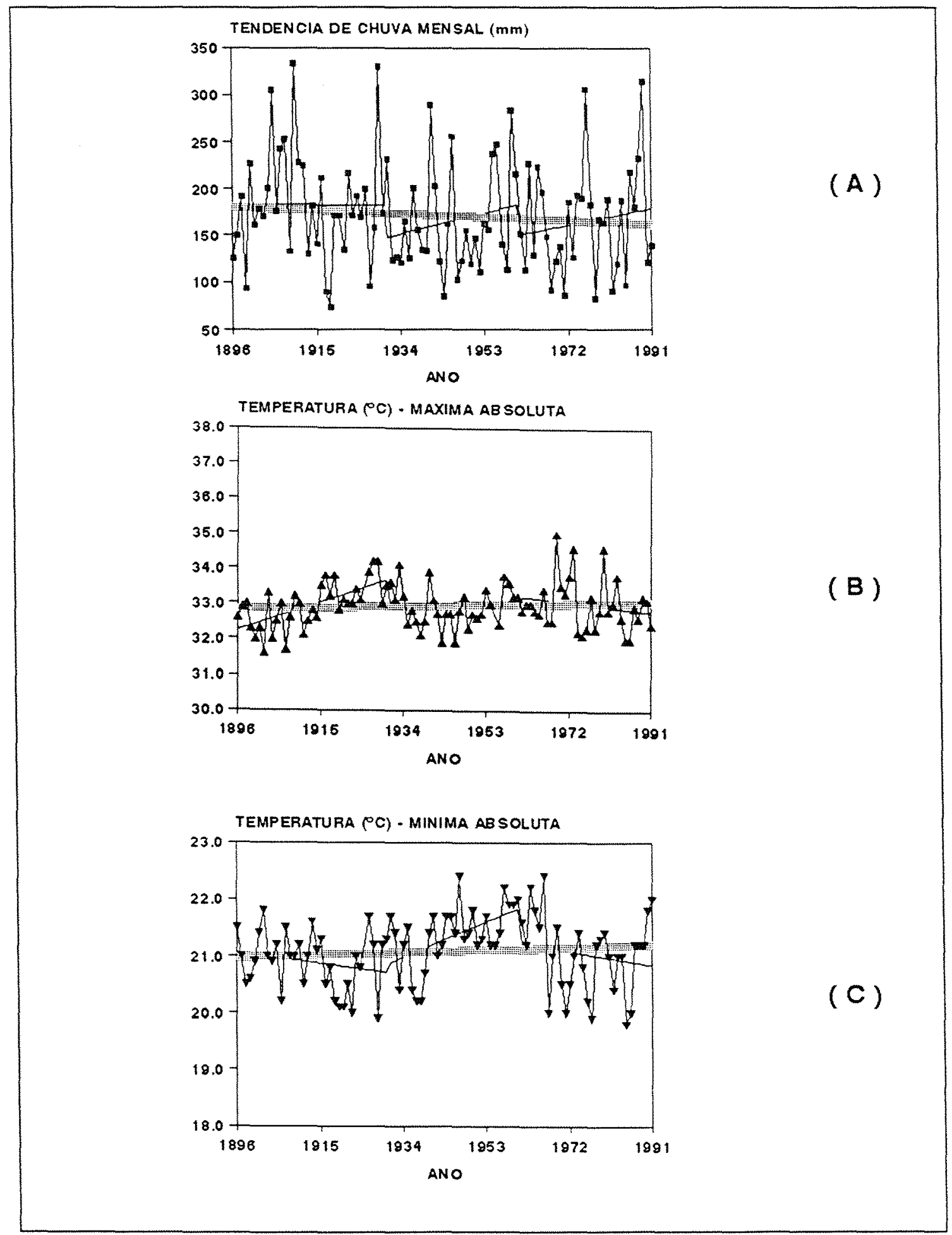

Figura 35 - Variação do total de chuva do mês de junho (a), variação da temperatura máxima absoluta no mês de junho (b), variação da temperatura mínima absoluta no mês de junho (c), períodos: $(1896$ - 1991), (1896-1930), (1931-1960), (1961 - 1991). Fonte dos dados brutos: INMET. 


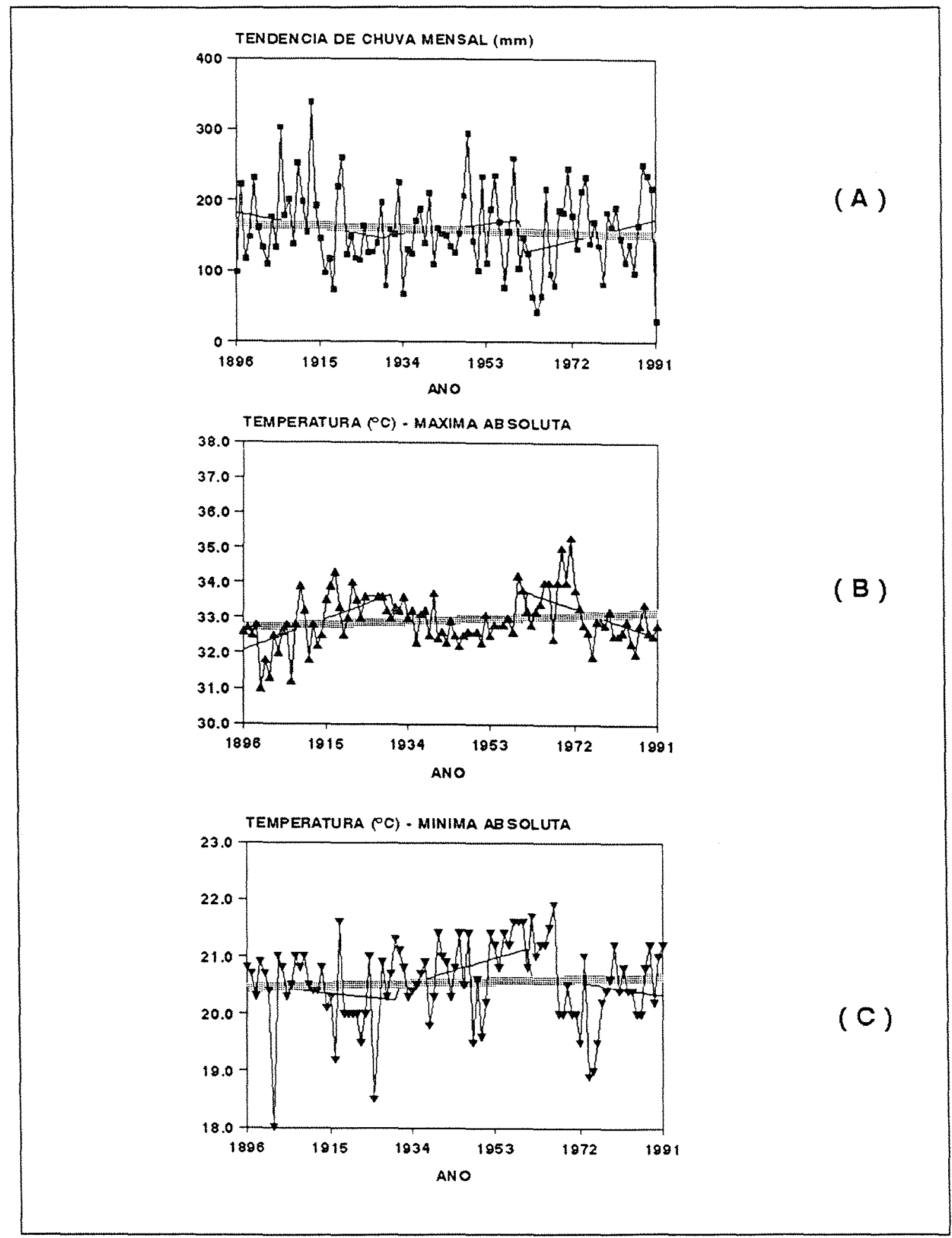

Figura 36 - Variação do total de chuva do mês de julho (a), variação da temperatura máxima absoluta no mês de julho (b), variação da temperatura mínima absoluta no mês de julho (c), períodos: $(1896-1991),(1896-1930),(1931-1960)$, (1961 - 1991). Fonte dos dados brutos: INMET. 


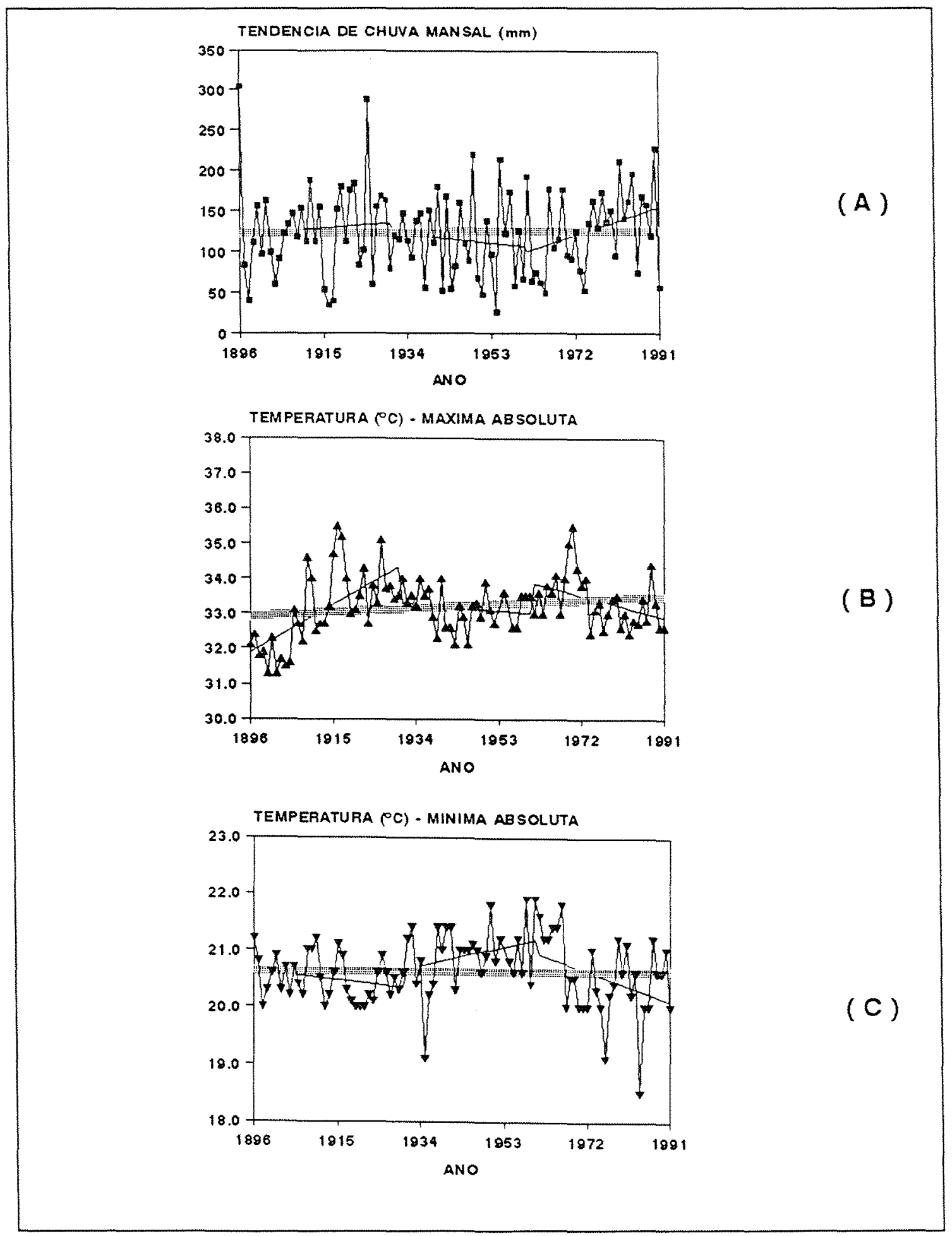

Figura 37 - Variação do total de chuva do mês de agosto (a), variação da temperatura máxima absoluta no mês de agosto (b), variação da temperatura mínima absoluta no mês de agosto (c), períodos: $(1896-1991),(1896-1930),(1931-1960)$, (1961 - 1991). Fonte dos dados brutos: INMET. 


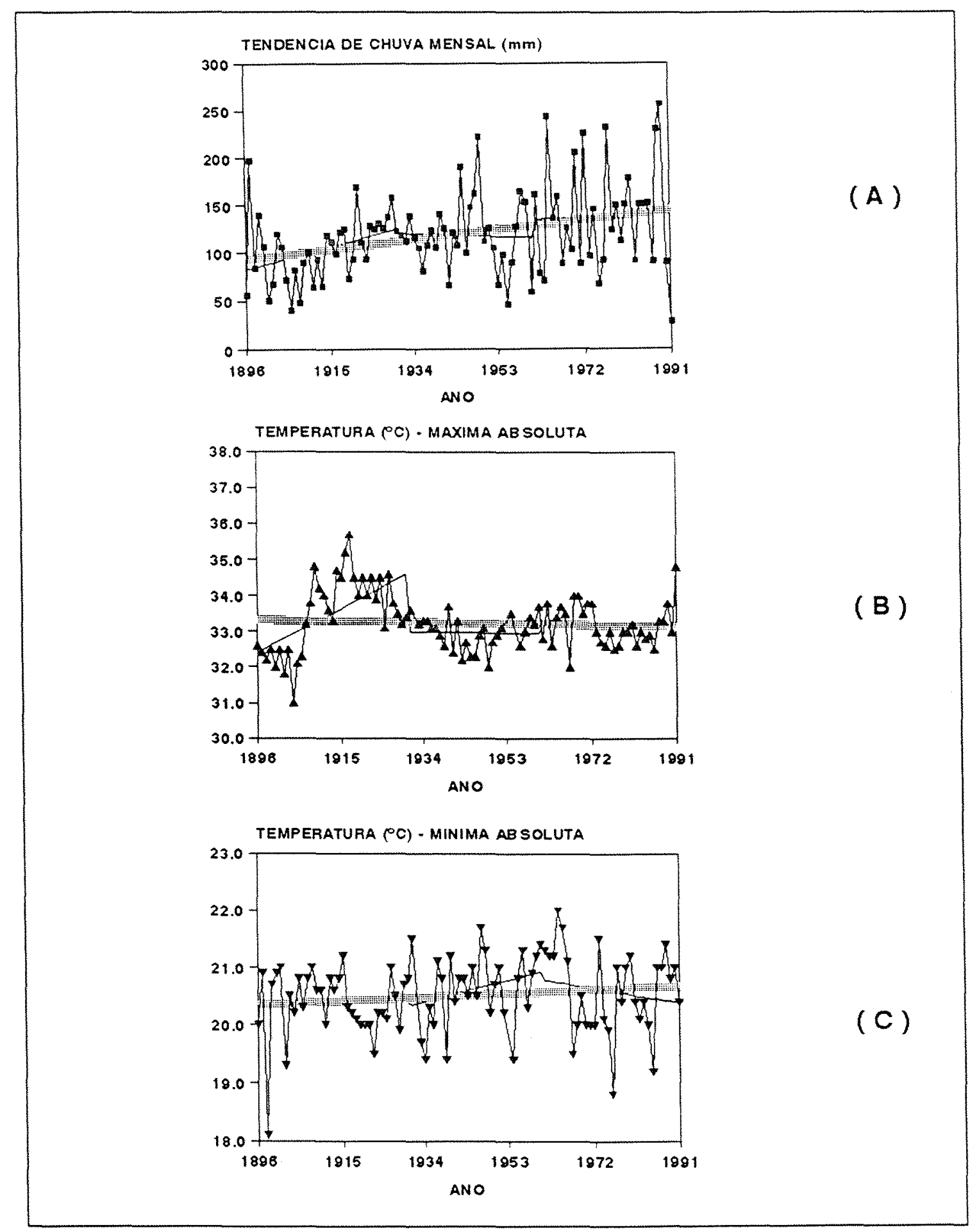

Figura 38 - Variação do total de chuva do mês de setembro (a), variação da temperatura máxima absoluta no mês de setembro (b), variação da temperatura minima absoluta no mês de setembro (c), períodos: $(1896$ - 1991), $(1896-1930)$, $(1931-1960),(1961-1991)$. Fonte dos dados brutos: INMET. 


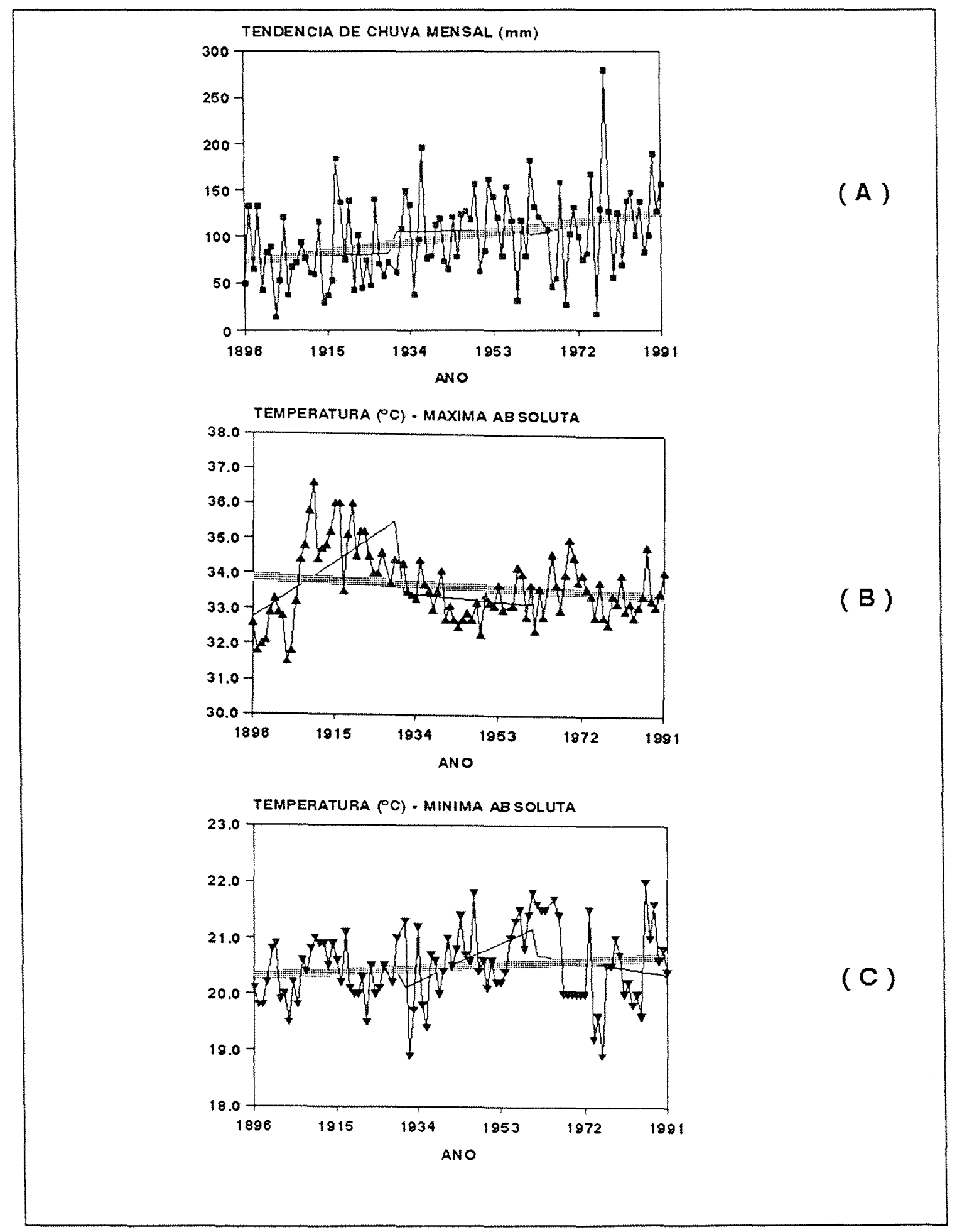

Figura 39 - Variação do total de chuva do mês de outubro (a), variação da temperatura máxima absoluta no mês de outubro (b), variação da temperatura mínima absoluta no mês de outubro (c), períodos: $(1896-1991),(1896-1930), \quad(1931-1960)$, $(1961$ - 1991). Fonte dos dados brutos: INMET. 


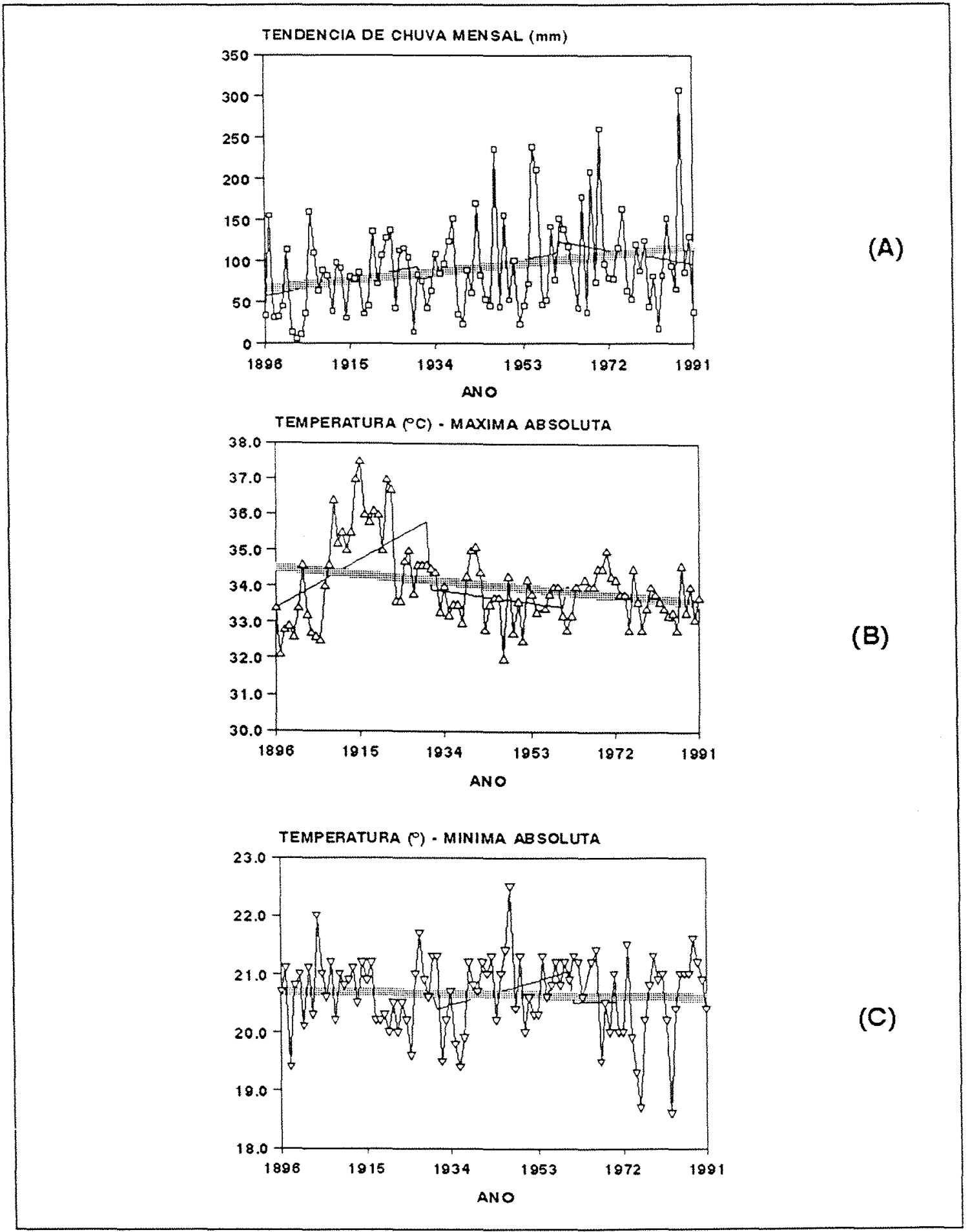

Figura 40 - Variação do total de chuva do mês de novembro (a), variação da temperatura máxima absoluta no mês de novembro (b), variação da temperatura minima absoluta no mês de novembro (c), periodos: $(1896$ - 1991), $(1896-1930)$, $(1931$ - 1960), (1961 - 1991). Fonte dos dados brutos: INMET. 


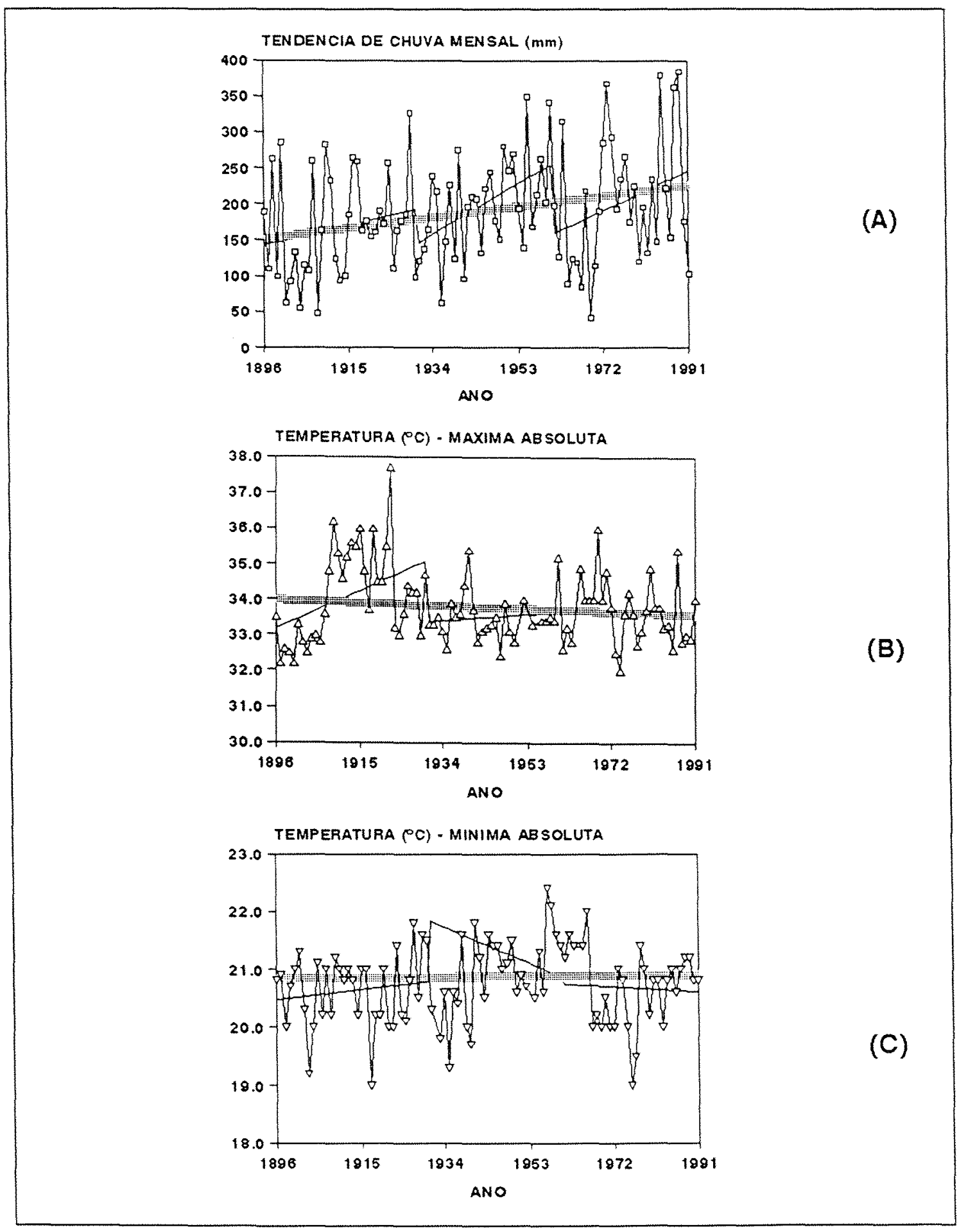

Figura 41 - Variação do total de chuva do mês de dezembro (a), variação da temperatura máxima absoluta no mês de dezembro (b), variação da temperatura mínima absoluta no mês de dezembro (c), periodos: $(1896-1991), \quad(1896-1930)$, $(1931$ - 1960), $(1961$ - 1991). Fonte dos dados brutos: INMET. 


\subsection{Efeito do ENOS sobre as Chuvas}

- estudo da influência das Anomalias de Temperatura no Pacífico Sul (ATPS), na região do $\mathrm{Niño} 1+2$, no índice de chuva em Belém (ICB) foi realizado através do acompanhamento mensal da correlação entre ATPS e ICB, cujos valores são mostrados na Tabela 7. A correlação entre esses valores é mostrado na figura 42 .

Tabela 7 - Correlação entre ATPS e ICB (1987 à 1991).

\begin{tabular}{|c|c|c|c|c|c|c|c|c|c|c|}
\hline \multirow{2}{*}{ Mês } & \multicolumn{9}{|c|}{1987} & \multicolumn{2}{|c|}{1988} & \multicolumn{2}{c|}{1989} & \multicolumn{2}{c|}{1990} & \multicolumn{2}{c|}{1991} \\
\cline { 2 - 12 } & AIPS & ICB & ATPS & ICB & ATPS & ICB & ATPS & ICB & ATPS & ICB \\
\hline JAN & 1.3 & 0.2 & 0.4 & 0.4 & -0.4 & 0.1 & 0.2 & -0.6 & 0.0 & 0.1 \\
\hline FEV & 1.3 & 0.0 & 0.3 & -0.2 & 0.1 & 0.2 & 0.3 & -0.1 & 0.5 & 0.1 \\
\hline MAC & 1.9 & 0.1 & 0.2 & 0.2 & 0.3 & -0.1 & 0.3 & -0.6 & 0.5 & 0.1 \\
\hline ABR & 1.8 & -0.1 & -0.5 & 0.1 & -0.1 & 0.3 & -0.2 & 0.0 & -0.3 & -0.2 \\
\hline MAI & 1.8 & -1.3 & 0.3 & 0.0 & -0.6 & 0.3 & 0.5 & -0.5 & 0.5 & -0.1 \\
\hline JUN & 1.0 & 0.0 & -1.5 & 0.3 & -0.6 & 0.5 & 0.5 & -0.4 & 0.4 & -0.2 \\
\hline JUL & 1.4 & 0.0 & -1.2 & 0.4 & -0.1 & 0.3 & -0.6 & 0.3 & 0.9 & -4.4 \\
\hline AGO & 1.2 & 0.3 & -1.3 & 0.2 & -0.1 & 0.0 & -0.1 & 0.5 & 0.3 & -1.2 \\
\hline SET & 1.1 & -0.3 & -1.1 & 0.5 & -0.5 & 0.5 & 0.0 & -0.3 & 0.3 & -3.2 \\
\hline OUT & 2.1 & -0.2 & 0.6 & 0.0 & -0.2 & 0.5 & -0.4 & 0.2 & 0.4 & 0.4 \\
\hline NOV & 1.5 & -0.4 & -0.3 & 0.7 & -0.1 & -0.1 & -0.1 & 0.3 & 0.4 & -1.5 \\
\hline DEZ & 1.1 & -0.2 & -0.1 & 0.5 & 0.3 & 0.5 & 0.0 & -0.1 & 0.7 & -0.8 \\
\hline
\end{tabular}




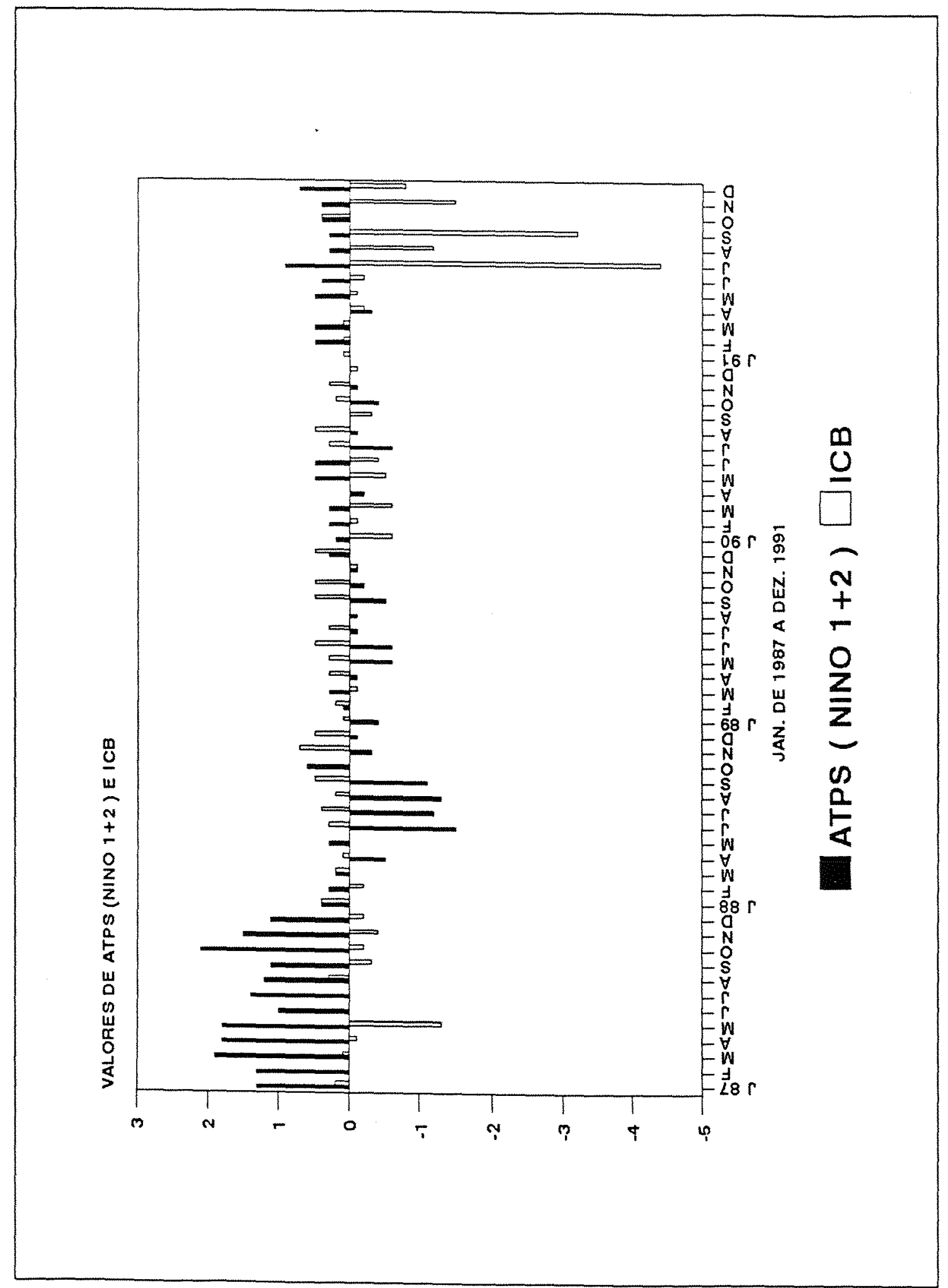

Figura 42 - Correlação entre ATPS (Niño 1+2) e ICB. período: $(1987$ - 1991).

Fonte de dados: 1) ATPS (Niño 1+2) - CLIMANÁLISE 2) ICB - INMET. 
Verifica-se, que no primeito trimestre, janeiro a março, do ano de 1987 o episódio ENOS, que teve início em 1986, alcançou sua fase madura apresentando uma intensidade moderada. Na regiāo Niño $1+2$ as ATPS para os meses de janeiro, fevereiro e março foram positivas, sendo que em janeiro e fevereiro o episódio se mostrou mais atuante no Pacifico central e ocidental, menos marcante no Pacifico Oriental e Costa Oeste da América do Sul. Nesses meses, sua área de máxima atividade encontrou-se a mais de $1000 \mathrm{~km}$ da Costa Oeste da América do sul e pela primeira vez durante esse episódio o indice de temperatura da superficie do Mar (TSM) para região Niño $1+2$ excedeu a $1{ }^{\circ} \mathrm{C}$ (os valores em janeiro e fevereiro foram $1,3^{\circ} \mathrm{C}$ ). Em março, o maior aumento da ATPS ocorreu na região ao longo da Costa oeste da América do sul onde os valores foram superiores a $1,8{ }^{\circ} \mathrm{C}$, consequentemente ocorreu um aumento na convecçāo nessa região.

Em Belém, as chuvas no primeiro trimestre de 1987 apresentaram-se ligeiramente acima da média climatológica. O número de dias de ocorrência de chuva nos meses de janeiro, fevereiro e março foram respectivamente 25, 27 e 27 dias. Nesse período as variações de chuva na região estiveram associadas às migrações da ZCIT. Em geral, quanto mais próxima da costa estiver a ZCIT, maior será o número de sistemas convectivos sobre o contimente, e, portanto, maior será a quantidade de chuva. Nas primeiras semanas de janeiro a ZCIT progrediu rapidamente para as 
baixas latitudes do Hemisfério sul provocando a penetraçāo para o continente de linhas de cumulos-nimbos associada à brisa maritima. Essas penetrações ocorreram nos dias 1, 4, $6,7,16$ e 17. Na primeira semana de fevereiro, a ZCIT deslocou-se para o Norte, o que resultou num período de pouca chuva na região. Posteriormente, moveu-se ligeiramente para o sul sendo observada próximo a Costa Norte do Brasil em várias ocasiōes, associada à chuva convectiva na região. Em março, durante a maior parte do mês, situou-se ao sul do Equador oscilando entre $2{ }^{\circ} \mathrm{N}$ e $4^{\circ} \mathrm{S}$.

No segundo trimestre de 1987, o episódio ENOS continuou em sua fase madura, sendo que em junho começou a apresentar sinais de declínio. Nos meses de abril e maio as ATPS permeneceram semelhantes à de março, ocorrendo em abril uma ligeira diminuição das ATPS na região próximo da costa Oeste da América do Sul. Em junho as ATPS continuaram, no entanto, esse mês apresentou uma diminuição nas ATPS ao longo da costa sul-americana e uma diminuição na intensidade da atividade convectiva no Pacifico central Equatorial. Tais fatos passaram a indicar os primeiros sinais de enfraquecimento do ENOS. No entanto, a falta de aumento significativo na intensidade dos ventos equatoriais de leste impediram o retorno rápido às condições normais.

Em Belém, o segundo trimestre de 1987, apresentou um número de dias de ocorrência de chuva igual aos valores de 28,18 e 21 dias, para os meses de abril, maio e junho, respectivamente. Em abril, os valores de chuva 
foram ligeiramente abaixo da média com um ICB de $-0,5$. Durante esse mês, a ZCIT permaneceu afastada da costa litorânea situando-se entre $29 \mathrm{~N}$ e ${ }^{\circ} \mathrm{N}$. Este posicionamento normalmente inibe o surgimento de sistemas de grande e mesoescalas causadores de chuva, sendo por isto comumente associado com período em que as chuvas em Belém apresentamse abaixo da média. O mês de maio do ano de 1987 destacou-se como sendo o que apresentou o menor ICB correspondente ao valor -1.3. Nesse mês, as chuvas que ocorreram foram em consequência de aglomerados convectivos com formação no Atlântico e estendendo-se continente adentro nos dias 5, 10 , 25 e 26. Junho apresentou valores de chuvas igual a média climatológica, pois apesar da ZCIT oscilar entre $5^{\circ} \mathrm{N}$ e $8 \mathrm{~N}$ ocorreram formação de linhas de cumulos-nimbos na costa litorânea nos dias $2,3,4,5,10,11,19,25,26$ e 28 .

No terceiro trimestre de 1987, o episódio ENOS continuou em sua fase madura, após decrescer em junho. Nesse trimestre, ocorreu um Iigeiro aumento das ATPS, apresentando valores en torno de $1,0^{\circ} \mathrm{C}$. Consequentemente, o episódio voltou apresentar poucas indicações de retorno às condições normais. Nos meses de julho, agosto e setembro a configuração das ATPS mostrou-se semelhante a dos últimos cinco meses do ano, com águas mais aquecidas desde a costa oeste da América do Sul Tropical até o Pacífico Equatorial central.

Nesse trimestre, Belém apresentou um número de dias de ocorrência de chuva igual aos valores de 16,17 e 11 
dias, para os meses de julho, agosto e setembro, respectivamente. A chuva não foi influenciada pela ZCIT que oscilou de $5^{\circ} \mathrm{N}$ a $9^{\circ} \mathrm{N}$. Em julho, as chuvas apresentaram-se em torno da média climatológica. Nesse mês, as linhas de cumulos-nimbos, que formaram-se na costa Atlântica associadas à brisa maritima, propagaram-se para o interior do contimente nos dias $5,6,7,8,9,27,28,29$ e 30 . Em agosto, as chuvas apresentaram registros acima da média climatológica com um ICB de 0,3. Por efeito de brisas, cinco Iinhas de cumulos-nimbos formaram-se no litoral norte e deslocaram para o continente. No mês de setembro, os registros de chuva apresentaram-se abaixo da média climatológica com um ICB de $-0,3$, ocorrendo, próximo da altitude de Belém, penetração de linhas de cumulos-nimbos com formação na costa Atlântica, nos dias 1, 3, 8, 17, 19, $21,23,24$ e 25 .

No quarto trimestre do ano de 1987 , observou-se que o episódio ENOS persistia há mais de um ano. No entanto, sua intensidade ainda foi considerada moderada. Alguns indicadores atmosféricos apontavam uma tendência de lento retorno às condições normais. Porém, as ATPS continuavam substancialmente acima do normal na maior parte do oceano Pacifico Tropical. O mês de outubro apresentou a maior ATPS do ano, correspondente ao valor de $2,1{ }^{\circ} \mathrm{C}$. Nos meses de novembro e dezembro ocorreram diminuidas ATPS na região próximo da Costa oeste da América do Sul. Nesse trimestre, verificou-se que a região de Belém apresentou chuvas abaixo 
da média climatológica. Observou-se uma perfeita correlação entre ATPS e ICB. Em Belém, o número de dias de ocorrência de chuva foi igual aos valores de 9,8 e 16 dias, para os meses de outubro, novembro e dezembro, respectivamente. Nos meses de outubro e novembro a ZCIT não exerceu influência sobre a chuva na região, pois permaneceu oscilando entre 5 ${ }^{\circ} \mathrm{N}$ e $9{ }^{\circ} \mathrm{N}$, sendo que, no final de dezembro começou a deslocar-se para o hemisfério sul oscilando entre 7 o N e 3 N. Em outubro, as linhas de cumulos-nimbos com formação na costa Atlântica mostraram-se enfraquecidas, não apresentando nenhuma penetração significativa dos 16 casos ocorridos no mês. Em novembro e dezembro, de modo geral, as linhas de cumulos-nimbos que formaram-se na costa Atlântica associadas à brisa maritima apareceram com intensidade que variou de média a fraca, ocorrendo poucos casos que penetraram no continente.

o ano de 1988 começou com o primeiro trimestre apresentando o episódio ENOS com indícios de declínio, sendo que em março o epiśodio já havia desaparecido, com quase a totalidade dos indicadores atmosféricos encontrando-se em condições próximas das normais. Nesse trimestre as ATPS, apesar de apresentarem-se positivas, sofreram pela primeira vez uma diminuição significativa tanto em área quanto em magnitude com anomalias positivas não ultrapassando a $1{ }^{\circ} \mathrm{C}$. os valores de ATPS em janeiro, fevereiro e março foram de $0,4{ }^{\circ} \mathrm{C}, 0,3{ }^{\circ} \mathrm{C}$ e $0,2{ }^{\circ} \mathrm{C}$, respectivamente. 
Em Belém as chuvas em janeiro do ano de 1988, foram acima da média climatológica apresentando um ICB de 0,4 . O número de dias de ocorrência de chuva foi de 28 dias, a ZCIT cruzou o Equador em várias ocasiōes vindo a ocupar posições no Hemisfério Sul, sendo a posição média em torno de $2^{\circ}$ para sul em relação a sua posição climatológica. Em fevereiro, as chuvas em Belém foram abaixo da média climatológica apresentando um ICB de $-0,2$. o número de dias de ocorrência de chuva foi de 25 dias. No final do mês, a ZCIT moveu-se para o hemisfério Norte, contribuindo para a ocorrência de desvios negativos das chuvas. Em março as chuvas em Belém foram acima da média climatológica apresentando um ICB de 0,2 , o número de dias de ocorrência de chuva foi de 29 dias. Nesse mês a ZCIT oscilou entre $1,0{ }^{\circ} \mathrm{N}$ e $2,0^{\circ} \mathrm{S}$.

No primeiro semestre de 1988, as linhas de cumulos-nimbos associada a brisa maritima comportaram-se de tal maneira que em janeiro ocorreram treze casos, sendo que nos dias 06, 07, 08, 09, 15, 16, 17, 19 e 30 atingiram a posição com relação a latitude da região de Belém. Em fevereiro dos 17 casos de linhas de cumulos-nimbos que formaram-se na costa Atlântica associada a brisa maritima somente nos dias 01, 02, 05, 06, 07, 08, 12, 13, 24 e 27 atingiram os limites latitudinais de Belém. Em março ocorreram treze casos no litoral norte, nas áreas entre a ilha do Marajó e o Nordeste do Brasil, sendo que 7 casos propagaram-se sobre o continente e juntaram-se à 
nebulosidade intensa existente na região, provocando o aumento da quantidade de chuva.

No segundo trimestre do ano de 1988, as ATPS alternaram-se de tal maneira que em abril, maio e junho apresentaram os valores $-0,5,0,3$ e $-1,5$, respectivamente. Nesse trimestre, o fato que mereceu destaque especial foi o resfriamento das áquas do Pacífico Equatorial. A expansão das águas mais frias ocorreram no lado leste desse oceano. Nesse período, observou-se que o campo de vento dos baixos níveis mostraram, em toda a extensão do Pacífico Equatorial, anomalias de leste razoavelmente fortes caracterizando uma provável fase contrária ao episódio ENOS, chamada de Anti-El Niño.

Nesse trimestre, Belém apresentou um número de dias de ocorrência de chuvas igual aos valores de 29,29 e 24 dias, para os meses de abril, maio e junho, respectivamente. Em abril, os valores de chuva foram ligeiramente acima da média climatológica com um ICB de 0,1. Durante esse mês, a ZCIT oscilou entre $3,0{ }^{\circ} \mathrm{N}$ e $2,0^{\circ} \mathrm{N}$, verificando-se que houve um aumento do número de ocorrências de Iinhas de cumulos-nimbos com formação na costa Atlântica, as quais estiveram presentes durante todo o mês e formaramse na região Nordeste da América do sul, entre a ilha de Marajó e Natal. Em maio, as chuvas em Belém apresentaram-se com o valor igual a média climatológica, pois nesse período a ZCIT esteve em sua posição climatológica oscilando entre $2,0^{\circ} \mathrm{N}$ e $5,0^{\circ} \mathrm{N}$. Nesse trimestre, as linhas de cumulos-nimbos 
que formaram-se na costa Atlântica associadas à brisa maritima comportaram-se de maneira bem típica, ou seja, formando-se as 18:00 horas TMG e intensificando-se às 21:00 horas TMG, propagando-se sobre o continente nos dias 18, 22, 28 e 30, com intensidade muito forte, forte e fraca. As chuvas em junho apresentaram registros acima da média climatológica com um ICB de 0,3, a ZCIT apresentou uma oscilação entre $2{ }^{\circ} \mathrm{N}$ e $8^{\circ} \mathrm{N}$, sendo que ocorreram várias chuvas ocasionais intensas em consequência de aglomerados convectivos e linhas de instabilidade que propagaram-se de leste para oeste na faixa litorânea.

Os valores de ATPS, no terceiro trimestre de 1988, permaneceram negativos, caracterizando que a fase contrária à observada durante o episódio ENos estava firmemente estabelecida no oceano Pacífico Equatorial. As ATPS apresentaram os valores de $-1,2{ }^{\circ} \mathrm{C},-1,3{ }^{\circ} \mathrm{C}$ e $-1,1{ }^{\circ} \mathrm{C}$ para os meses de julho, agosto e setembro, respectivamente. Nesse trimestre, a quantidade de chuva em Belém foi acima da média climatológica, mostrando que os valores de ICB foram inversamente proporcional aos valores de ATPS. os meses de julho, agosto e setembro apresentaram um número de dias de ocorrência de chuva igual aos valores de 19, 9 e 19 dias, respectivamente. Julho apresentou um ICB correspondente ao valor 0,4 , sendo que a ZCIT oscilou entre 4,0 o $\mathrm{e}$ $7,0^{\circ} \mathrm{N}$, e sua posição média mensal foi de aproximadamente $2^{\circ}$ ao sul da posição climatológica. Portanto, verifica-se que a ZCIT não influenciou para que a quantidade de chuva em 
Belém fosse acima da média climatológica. Nesse mês, aglomerados convectivos formaram-se ou intensificaram-se no litoram norte, deslocaram-se para oeste ocasionando chuvas inten sas na região. Julho apresentou um comportamento típico para as linhas de cumulos-nimbos na costa Atlântica, pois formaram-se as 18:00 TMG e intensificaram-se as 21:00 TMG. Nesse mês, foi possível identificar quatro períodos distintos, de acordo com a intensidade das Iinhas de cumulos-nimbos, com formação na costa Atlântica: de 10 a 12, de 13 a 15 , de 17 a 22 , e de 24 a 31 . Nos dias iniciais do primeiro período, as linhas de cumulos-nimbos com formação na costa Atlântica foram mais fracas e localizaram-se em latitudes mais ao norte do que nos dias finais deste período. Durante $\circ$ segundo período, as linhas de cumulonimbos com formação na costa Atlântica apresentaram-se consideravelmente fracas. No Ínicio do terceiro período, as linhas de cumulos-nimbos com formação na costa Atlântica apresentaram-se mais intensas e no ültimo período houve formação de linhas de cumulos-nimbos na costa Atlântica, gradualmente mais intensas até ocorrer uma linha de cumulosnimbos muito forte no dia 25. A partir do dia 25 as Iinhas de cumulos-nimbos formaram-se gradativamente com menor intensidade. O mês de agosto apresentou ICB igual a 0,2 sendo que a ZCIT não influenciou na quantidade de chuva em Belém e apresentou uma oscilação bastante intensa, cuja posição variou, entre $4,0{ }^{\circ} \mathrm{N}$ e $10,0^{\circ} \mathrm{N}$. Essa oscilação foi bem maior que a prevista climatológicamente para agosto, mês 
em que a zCIT apresenta seus menores desvios em relação à média. Durante quase todos os dias de agosto, ocorreram formações de Iinhas de cumulos-nimbos na costa Atlântica, em geral, entre as latitudes de $8,0^{\circ} \mathrm{N}$ e $2,0^{\circ} \mathrm{N}$, as quais contribuiram para manter a atividade convectiva na região de Belém. Setembro apresentou ICB igual a 0,5 , sendo que a $\mathrm{ZCIT}$ oscilou entre $5,0^{\circ} \mathrm{N}$ e $9,0^{\circ} \mathrm{N}$, com uma posição média ligeiramente no sul da média climatológica para essa época do ano, - que influenciou para que as chuvas em Belém apresentasse uma quantidade acima da média climatológica. Durante quase todos os dias de setembro ocorreram formações de Iinhas de cumulos-nimbos na costa Atlântica, com o tempo de vida das atividades convectivas a tais Iinhas, em média menor que a do mês anterior, o que indica que durante setembro houve um enfraquecimento na atividade convectiva associada às Iinhas de cumulos-nimbos com formação na costa Atlântica.

No último trimestre do ano de 1988, observou-se que o episódio anti - El Niño continuou a dominar a circulação no Pacífico Tropical. No entanto, na região do El Niño $1+2$ as ATPS apresentaram valores positivos em outubro $\left(0,6^{\circ} \mathrm{C}\right)$ e negativos em novembro $\left(-0,3^{\circ} \mathrm{C}\right)$ e dezembro $\left(-0,1^{\circ} \mathrm{C}\right)$.

Em Belém, verificou-se que nesse trimestre a quantidade de chuva apresentou valores em torno da média climatológica em outubro e valores acima da média nos meses de novembro e dezembro, os valores de ICB foram respectivamente de $0,0,0,7$ e 0,5 . Os números de dias de ocorrência de chuva foram de 12 dias em outubro, 22 dias em 
novembro e 25 dias em dezembro. Em outubro, a ZCIT não influenciou na quantidade de chuva e oscilou entre 7,0 $\mathrm{N}$ e 11,0 N com uma posição média em $8,3^{\circ} \mathrm{N}$ aproximadamente $0,5^{\circ}$ ao norte de sua posição média climatológica. Nesse mês, ocorreram dezessete linhas de cumulos-nimbos associadas à brisa maritima com formação na costa Atlântica, dos quais seis apresentaram deslocamento para o interior do continente, sendo que sete foram de intensidade forte, sete fraca e três média. Em novembro, a posição da ZCIT foi, principalmente em meados do mês, bastante influenciada por sistemas do Hemisfério Norte, o que a levou à latitudes mais ao norte na primeira quinzena. Na segunda quinzena de novembro, a ZCIT atingiu posições mais ao sul, como é esperado nessa época do ano, quando começa a retornar a suas posições mais próximas ao Equador. Durante o mês de novembro, ocorreram dezoito linhas de cumulos-nimbos que se organizaram sobre a costa norte da América do Sul. Destas linhas de cumulos-nimbos, sete apresentaram deslocamento, sendo que sobre o norte do Brasil apenas quatro linhas se deslocaram, as quais penetraram pouca extensão latitudinal. Em dezembro, a ZCIT deslocou-se rapidamente em direção ao Equador, oscilou entre $0,0^{\circ} \mathrm{C}$ e $6,5^{\circ} \mathrm{N}$, com uma posição média em 3,0 $\mathrm{N}$, comparada com sua posição média climatológica, esteve $1,8^{\circ}$ ao sul. Durante dezembro, ocorreram vinte linhas de cumulos-nimbos, que se organizaram sobre a costa norte da América do sul, das quais oito apresentaram deslocamento para o continente. 
o primeiro trimestre do ano de 1989, apresentou indícios de declínio do fenômeno anti-El Niño, muito embora em janeiro, na região do Niño $1+2$ as ATPS persistiram negativas com valores de até $-0,4{ }^{\circ} \mathrm{C}$. Os meses de fevereiro e março mostraram que o anti - El Niño caminhava para sua fase terminal, apresentando sinais de dissipação, pois já se observava ATPS positivas na região próxima à costa do Perú. Na região de Belém, verificou-se que no primeiro trimestre de 1989, a quantidade de chuva apresentou-se ligeiramente próxima da média climatológica. Nos meses de janeiro e fevereiro os valores de $\operatorname{ICB}$ foram de 0,1 e 0,2 , respectivamente, sendo $-0,1$ o valor do mês de março. Os números de dias de ocorrência de chuva foram de 28 dias em janeiro, 27 dias em fevereiro e 26 dias em março. No começo desse trimestre a ZCIT continuou sua marcha para o Hemisfério sul, sendo que em março suas posições estavam mais próxi mas ao Equador influenciando, principalmente durante a segun da quinzena do mês, na quantidade de chuva da região. Em janeiro, foram observados 32 casos de linhas de cumulosnimbos associada à brisa marítima com formação na costa Atlântica, sendo que a maior parte dos casos ocorridos apresentaram intensidade forte, oito casos apresentaram intensidade média, e dois casos de intensidade fraca. Nos meses de fevereiro e março as linhas de cumulos-nimbos associada à brisa marítima se formaram junto a costa, ficando confinadas entre a Ilha de Marajó e a costa do Nordeste brasileiro, portanto não penetrando para o interior 
do continente.

O fenômeno anti - El Niño para o segundo trimentre do ano de 1989, apresentou-se com uma tendência de dissipação. Em abril, na região do Niño $1+2$, observou-se que as ATPS sofreram um decréscimo quando comparado com as observadas em fevereiro e março. Isso mostrava uma tendência de retorno às condições normais. Os valores de ATPS para os meses de maio e junho foram de $-0,6{ }^{\circ} \mathrm{C}$. No entanto, esses valores de anomalias negativas foram constatadas somente na região do Niño $1+2$. No restante do oceano Pacífico Equatorial, observou-se que a magnitude das ATPS apresentaram-se próxima de zero.

Em Belém, observou-se que nesse trimestre a quantidade de chuva apresentou-se próximo da média climatológica, com valores de ICB de 0,3 em abril e maio e 0,5 para o mês de junho. No trimestre, constatou-se uma correlação entre ATPS e ICB. Os números de dias de ocorrência de chuva foram de 29 dias em abril, 27 dias em maio e 23 dias em junho. No mês de abril as chuvas apresentaram quantidades maiores que $500 \mathrm{~mm}$ no nordeste do Estado do Pará. Um indicativo de que as chuvas foram superiores à normal climatológica na região foi o fato da radiação de onda longa emitida para o espaço apresentar anomalias negativa. A ZCIT influenciou diretamente no comportamento das chuvas, apresentando-se numa posição média de $0,7 \mathrm{~N}$. Durante abril, dezesseis Iinhas de cumulos-nimbos com formação na costa Atlântica apresentaram deslocamento 
para o interior do continente, sendo que nos cinco primeiros dias do mês as linhas de cumulos-nimbos ocorreram ao sul do Equador e, a partir do dia 6 , passaram a se estender ao norte do Equador intensificando-se bastante. Em maio, a ZCIT apresentou uma posição média em 2,8 ' $N$. Consequentemente, iniciando claramente o seu retorno para o Hemisfério Norte, porém ainda influenciando na quantidade de chuva em Belém. Nesse mês as linhas de cumulos-nimbos com formação na costa Atlântica, apresentaram um aspecto bastante interessante, ou seja, na maior parte dos dezoito casos observados, as linhas se deslocaram atingindo quase toda parte leste da Amazônia, provocando chuvas intensas sobre as regiões atingidas. No mês de junho, a ZCIT continuou caminhando para suas posiçōes mais ao Hemisfério Norte, sendo que sua posição média durante o mês foi de 06 graus ao sul de sua posição média climatológica do mês de junho. Isso mostra que provavelmente a zCIT não influenciou na chuvas ocorridas na região de Belém. Durante o mês de junho, observou-se que as linhas de cumulos-nimbos associadas à brisa marítima com formação na costa Atlântica, formaram-se ao norte do Equador, apresentando maior intensidade que as de formação ao sul do Equador. Nos casos ocorridos no mês de junho, cinco foram de forte intensidade e oito de intensidade média.

os valores de ATPS, no terceiro trimestre de 1989, apresentaram-se abaixo do valor médio climatológico, porém muito próximo deste. Os valores foram de $-0,1{ }^{\circ} \mathrm{C}$ em julho e agosto e de $-0,5{ }^{\circ} \mathrm{C}$ em setembro. 
Em Belém, o trimestre apresentou-se com quantidade de chuva acima da média climatológica nos meses de julho e setembro e igual a média climatológica no mês de agosto. Os meses de julho, agosto e setembro apresentaram um número de dias de ocorrência de chuva igual aos valores de 21, 15 e 17 dias, respectivamente. Julho apresentou um ICB correspondente ao valor de 0,3 e setembro um valor de 0,5 mostrando uma perfeita correlação entre os valores de ATPS e ICB. Nesse trimestre, a ZCIT começou a atingir suas posiçōes mais ao norte não influenciando diretamente na quantidade de chuva na região. Observou-se ainda, que o aparecimento de nebulosidade próximo da costa norte brasileira não foi relacionada com a ZCIT devido o seu afastamento para o Hemisfério Norte.

No último trimestre do ano de 1989, observou-se que as temperaturas da superficie do mar no Pacifico Equatorial apresentaram-se próximos da média climatológica. $\mathrm{Na}$ região $\mathrm{Niño} 1+2$, observou-se que nos meses de outubro e novembro os valores de temperatura média ficaram durante quase todo o período abaixo do valor médio climatológico, porém muito próximo deste. Em dezembro, na região Niño $1+2$, as águas aqueceram ligeiramente. Nessa região os valores da ATPS foram de $-0,2{ }^{\circ} \mathrm{C},-0,1{ }^{\circ} \mathrm{C}$ e $0,3{ }^{\circ} \mathrm{C}$ respectivamente para os meses de outubro, novembro e dezembro.

Em Belém, verificou-se que nesse trimestre a quantidade de chuva apresentou valores acima das médias nos meses outubro e dezembro, e valores abaixo das médias no mês 
de novembro. Os valores de ICB foram de 0,5 para os meses de outubro e dezembro, e -0,1 para o mês de novembro. O número de dias de ocorrência de chuva foram de 21 dias em outubro, 12 dias em novembro e 22 dias em dezembro. Em outubro, a ZCIT apresentou um ligeiro recuo para o sul, apresentando uma posição média mensal em torno de $5 \mathrm{o}$, o que significa $2,8^{\circ}$ ao sul de sua posição climatológica para este mês. Durante o mês de outubro observou-se uma caracteristica interessante de formação das linhas de cumulos-nimbos, ou seja a formação foi muito intensa no sentido longitudinal. Em novembro, a ZCIT retornou para o norte em relação à sua posição no mês anterior, atingindo uma posição média em $6^{\circ} \mathrm{N}$, próxima de sua aposição média climatológica, esse fato influenciou diretamente na quantidade de chuvas no mês. Desse período as linhas de cumulos-nimbos com formação na costa Atlântica, formaram-se até o dia 16 no Hemisfério sul e a partir desse dia formaram-se no Hemisfério Norte. Em dezembro, o aumento da quantidade de chuva foi influenciada diretamente pelo deslocamento da ZCIT para o sul em relação à sua posição no mês anterior, atingindo uma posição média mensal em torno de $3,5^{\circ} \mathrm{N}$, cerca de $1,2^{\circ}$ ao sul de sua posição média climatológica.

No primeiro trimestre do ano 1990, observou-se que os índices oceânicos e atmosféricos no Pacífico Tropical indicaram condiçōes de um episódio quente. As ATPS na região do Niño $1+2$ mostraram-se ligeiramente acima da média climatológica, apresentando valores de $0,2^{\circ} \mathrm{C}$ em janeiro e 
$0,3^{\circ} \mathrm{C}$ em fevereiro e março.

Em Belém, verificou-se que no primeiro trimestre de 1990 a quantidade de chuva apresentou valores abaixo da média climatológica nos meses de janeiro e março, e valores próximos a média climatológica no mês de fevereiro. Os valores de ICB foram de $-0,6$ para os meses de janeiro e março, e -0,1 para o mês de fevereiro. o número de dias de ocorrência de chuva foram de 24 dias em janeiro e 27 dias em fevereiro e março. Em janeiro, a ZCIT posicionou-se em torno de $2,5^{\circ} \mathrm{N}$, um pouco ao sul da posição média climatológica que é $2,9^{\circ} \mathrm{N}$. Em fevereiro a ZCIT continuou o seu deslocamento para posições mais ao sul em relação aos últimos meses, posicionando-se em 1,2\%, ligeiramente ao sul de sua posição média climatológica que é 1,5\%. Durante o mês de fevereiro, a característica mais marcante associada às Iinhas de cumulos-nimbos foi a divergência em altitude, - que impossibilitou, na região, a associação de linhas de cumulos-nimbos à formação de brisa. Em março, a ZCIT posicionou-se em torno de $1,5^{\circ} \mathrm{N}$, aproximadamente $1,0^{\circ}$ ao norte de sua posição média climatológica. Durante o mês de março, ocorreram 10 casos de linha de cumulos-nimbos associada à brisa maritima com intensidade média, 21 casos com intensidade forte e somente dois com intensidade fraca. A maioria das linhas de cumulos-nimbos com intensidade fraca ocorreram na primeira metade do mês, o que indica que a segunda metade do mês foi, em geral, mais forte. Nesse trimestre, pode-se afirmar que a baixa quantidade de chuva 
em relação a média climatológica foi causada principalmente pela fraca atividade convectiva na região da ZCIT.

No segundo trimestre do ano de 1990, observouse que os ventos alíseos de leste estiveram mais intensos do que a média climatológica, o que é indício do enfraquecimento das condições iniciais do evento ENOS. Contudo, as ATPS na região do Niño $1+2$, apresentaram valores acima da média climatológica nos meses de maio e junho. Os valores de ATPS são de $-0,2^{\circ} \mathrm{C}$ em abril e $0,5^{\circ} \mathrm{C}$ em maio e junho.

Em Belém, verificou-se que nesse trimestre a quantidade de chuva apresentou valores em torno da média climatológica no mês de abril, e abaixo da média climatológica nos meses de maio e junho. Os valores de ICB foram de $-0,5$ para o mês de maio, e $-0,4$ para o mês de junho. O número de dias de ocorrência de chuvas foi de 28 dias em abril, 21 dias em maio, e 17 dias em junho. Na primeira quinzena de abril, a ZCIT posicionou-se a $1,2^{\circ} \mathrm{N}$ de sua posição média climatológica apresentando atividade convectiva bastante fraca, causando deficiência da quantidade de chuva em Belém. Na segunda quinzena de abril, a ZCIT intensificou-se provocando bastante conveç̧ão e produziu chuvas na região. Nesse mês, ocorreram 25 casos de linhas de cumulos-nimbos com formação na costa Atlântica de intensidade forte, dois casos com intensidade fraca e sete casos de média intensidade. Em maio, a ZCIT posicionou-se em $3,6^{\circ} \mathrm{N}$, que é aproximadamente $0,5^{\circ}$ ao norte de sua posição 
média para esta época do ano, diminuindo sua influência sobre as chuvas em Belém. Em junho a ZCIT posicionou-se em torno de $4,8 \%$, que é aproximadamente $1,0^{\circ}$ ao sul de sua posição média climatológica. Porém, como é esperado para essa época do ano, a ZCIT não mais exerceu influência direta nas chuvas da região de Belém. No entanto, o fato que contribuiu para a quantidade de chuva apresentar-se abaixo da média climatológica nos meses de maio e junho foi a redução da atividade convectiva para a região de Belém. No mês de maio, foram observados 22 casos de linhas de cumulosnimbos com formação na costa Atlântica de forte intensidade, 15 de média intensidade, e apenas 2 de fraca intensidade. No mês de junho, as Iinhas de cumulos-nimbos se formaram mais pronunciadamente ao norte do Equador, sempre associada à ZCIT. Nesse mês, observou-se 17 casos de forte intensidade, 10 casos de média intensidade, e apenas 5 casos de fraca intensidade.

No terceiro trimestre do ano de 1990, observouse que os parâmetros atmosféricos e oceânicos no Pacífico Tropical tenderam a ficar próximos da média climatológica. $\mathrm{Na}$ região do Niño $1+2$, as ATPS apresentaram valores de $0,6^{\circ} \mathrm{C}$ em julho, $-0,1^{\circ} \mathrm{C}$ em agosto, e em setembro a temperatura das águas do mar foi igual a sua média climatológica.

Em Belém, verificou-se que nesse trimestre a quantidade de chuva apresentou valores acima da média climatológica nos meses de julho e agosto, e abaixo da média climatológica no mês de setembro. Os valores de ICB foram 
$0,3 \mathrm{em}$ julho, 0,5 em agosto e $-0,3$ em setembro. O número de dias de ocorrência de chuva foi de 26 dias em julho, 24 dias em agosto, e 21 dias em setembro. Nesse trimestre, a ZCIT não influenciou diretamente nas chuvas da região de Belém. No mês de julho, a ZCIT apresentou uma posição média em torno de $6,6^{\circ} \mathrm{N}$, que é aproximadamente $0,5^{\circ}$ ao sul de sua posição média climatológica para este mês. Nesse mês, foram observados ao todo 29 casos de Iinha de cumulos-nimbos com formaçāo na costa Atlântica, dos quais 11 foram de intensidade forte, 11 de intensidade média e 7 de intensidade fraca. Em agosto, a ZCIT oscilou entre $6{ }^{\circ} \mathrm{N}$ e $10 \%$, apresentando uma posição média de $7,1^{\circ} \mathrm{N}$, que é aproximadamente $1,0^{\circ}$ ao sul de sua posição média climatológica para este mês. Em agosto, os casos de Iinhas de cumulos-nimbos com formação na costa Atlântica, estiveram bem distribuidas quanto à intensidade, principalmente entre os casos de intensidade forte e média que alcançaram 11 e 10 ocorrências, respectivamente. Ocorreram apenas 5 casos de intensidade fraca totalizando 26 ocorrências.

Nos meses de julho e agosto, a conveç̧ão tropical sobre a região Amazônica restringiu-se, durante a maior parte desse período, às regiões ao norte de $6^{\circ} \mathrm{S}$. Essa foi a principal causa da quantidade de chuva da região de Belém apresentar-se acima da média climatológica.

Em setembro a ZCIT oscilou entre $4,9^{\circ} \mathrm{N}$ e $7,5^{\circ} \mathrm{N}$ com sua posição média em torno de $6,2^{\circ} \mathrm{N}$, que é aproximadamente $1,5^{\circ}$ ao sul de sua posição média 
climatológica para este mês. Nesse mês, ocorreram 21 casos de formação de linhas de cumulos-nimbos associadas à brisa marítima, as quais estão igualmente distribuídas em 7 ocorrências de intensidade forte, média e fraca. Observouse, que houve um enfraquecimento tanto no número de ocorrências de linhas de cumulos-nimbos quanto na sua atividade convectiva, o que causou um tempo de duração mais curto do que geralmente ocorre, motivo pelo qual a quantidade de chuva na região de Belém apresentou valores abaixo da média climatológica.

No último trimestre do ano de 1990, observou-se que os parâmetros atmosféricos indicativos do evento ENOS mostraram uma desaceleração da evolução em direção ao episódio quente. Na região do Niño 1+2, as ATPS apresentaram valores de $-0,4^{\circ} \mathrm{C}$ em outubro, $-0,1^{\circ} \mathrm{C}$ em novembro, e em dezembro a temperatura das águas do mar foi igual a sua média climatológica.

Em Belém, verificou-se que nesse trimestre a quantidade de chuva apresentou valores acima da média climatológica nos meses de outubro e novembro, e abaixo da média climatológica no mês de dezembro. Os valores de ICB foram de 0,2 em outubro, 0,3 em novembro, e $-0,1$ em dezembro. o número de dias de ocorrência de chuva foi de 16 dias em outubro e 20 dias em novembro e dezembro. Em outubro, a ZCIT oscilou entre $4,0^{\circ} \mathrm{N}$ e $9,0^{\circ} \mathrm{N}$ com uma média em torno de $6,7^{\circ} \mathrm{N}$, que é aproximadamente $1,0^{\circ}$ ao sul de sua média climatológica para este mês. Nesse mês, observou-se 
que as Iinhas de cumulos-nimbos com formação na costa Atlântica apresentaram-se com fraca intensidade na primeira quinzena e forte intensidade na segunda quinzena. Em novembro, a ZCIT oscilou entre $5,5^{\circ} \mathrm{N}$ e $9,5^{\circ} \mathrm{N}$, com uma média em torno de $7,0 \%$, o que representa a média climatológica para este mês. Nesse mês, observou-se que na primeira quinzena as linhas de cumulos-nimbos com formação na costa Atlântica estenderam-se sobre a região litorânea do continente ao norte do Equador e na segunda quinzena ficaram ao sul do Equador.

A principal causa da quantidade de chuva da região de Belém, apresentarem-se acima da média climatológica nos meses de outubro a novembro, foi o aumento da penetração de linhas de instabilidade para o continente em consequência dos ventos alíseos de nordeste apresentarem um núcleo de maior intensidade ao norte da linha de Marajó. Em dezembro, observou-se que o núcleo de maior intensidade dos alíseos de nordeste deslocou-se do norte da ilha de Marajó para as proximidades da costa Africana. Esse fato provocou uma diminuição na quantidade de chuvas da região de Belém. Nesse mês a ZCIT apresentou um deslocamento para o sul, com sua posição média ficando em torno de $4,5^{\circ} \mathrm{N}$. Poucas linhas de cumulos-nimbos com formação na costa Atlântica apresentaram penetração considerável para o interior do continente. No entanto, na região litorânea próxima de Belém, observou-se bastante formação de nuvens convectivas e cirros de bigornas associados à fatores de 
circulação sinótica.

O primeiro trimestre do ano de 1991 apresentouse inicialmente, no Pacífico Tropical, com as águas mais quentes do ocidente deslocando-se para leste, mostrando com isso uma evolução em direção ao episódio ENos. Contudo, em fevereiro, essa expansão sofreu um pequeno recuo para oeste e posteriormente, em março, observou-se que, a convecção no Pacifico Central e oriental em geral, estiveram bem abaixo da média climatológica, com isso caracterizando um recuo na evolução em direção ao evento ENOS.

$\mathrm{Na}$ região do Niño $1+2$, o mês de janeiro apresentou-se com a temperatura das águas do mar em torno da média climatológica, enquanto que nos meses de fevereiro e março as ATPS apresentaram valores de $0,5^{\circ} \mathrm{C}$.

Em Belém, verificou-se que nesse trimestre o valor de ICB foi igual a 0,1, mostrando que a quantidade de chuva nos meses de janeiro, fevereiro e março estiveram acima da média climatológica. o número de dias de ocorrência de chuvas foi 28 dias em janeiro, 25 dias em fevereiro e 30 dias em março.

Em janeiro, a atividade convectiva esteve bastante intensa em todo o Atlântico Equatorial, o que mostra que a ZCIT no Atlântico produziu conveç̧ão bem mais intensa que a sua atividade convectiva média climatológica. Nesse mês, a ZCIT apresentou-se numa posição média mensal em torno de $2,6^{\circ} \mathrm{N}$ e ainda ligeiramente ao sul de sua posição média climatológica. No mês de fevereiro, a ZCIT oscilou 
entre $2,2^{\circ} \mathrm{S}$ e $1,9^{\circ} \mathrm{N}$ apresentando sua média em $0^{\circ}$, que é aproximadamente $1,5^{\circ}$ ao sul de sua média climatológica para este mês. Em março, a ZCIT esteve mais intensa que a média oscilando entre $2,6^{\circ} \mathrm{N}$ e $4,2^{\circ} \mathrm{S}$, apresentando uma posição média em $0,2^{\circ} \mathrm{N}$, que é aproximadamente $0,5^{\circ}$ ao sul de sua média climatológica para este mês. Nesse trimestre, a ZCIT influenciou diretamente na quantidade de chuva na região de Belém.

Inicialmente, no segundo trimestre do ano de 1991, observou-se que as temperaturas da superfície do mar no Pacífico Tropical estiveram, em geral, mais elevadas do que a média climatológica, com excessão da região Equatorial, na costa da América do sul, que apresentou ATPS negativas. Em seguida, no mês de maio, observou um aumento das magnitudes das ATPS em todo o Pacífico tropical, indicando a possibilidade de surgimento de um novo episódio ENOS, que foi configurado no mês de junho, com a continuação das ATPS acima das médias climatológicas. Na região do Niño $1+2$, as ATPS apresentaram valores de $-0,3^{\circ} \mathrm{C}$ em abril, $0,5^{\circ} \mathrm{C}$ em maio, e $0,4^{\circ} \mathrm{C}$ em junho.

Em Belém, verificou-se que, nesse trimestre, a quantidade de chuva apresentou-se com valores abaixo da média climatológica, os valores de ICB foram de $-0,2$ em abril, $-0,1$ em maio, e -0,2 em junho. o número de dias de ocorrência de chuva foi de 28 dias em abril, 25 dias em maio e 21 dias em junho. 
Nesse trimestre, a ZCIT iniciou seu retorno sazonal para as posições mais ao norte. Em abril, a ZCIT apresentou uma oscilação entre $3,2^{\circ} \mathrm{S}$ e $2^{\circ} \mathrm{N}$, com uma posição média em torno de $0,9^{\circ} \mathrm{S}$, que é aproximadamente $2,0^{\circ}$ ao sul de sua posição média climatológica para este mês. Em maio, a ZCIT oscilou entre $1,0^{\circ} \mathrm{S}$ e $3,3^{\circ} \mathrm{N}$, com posições mais ao sul no início do mês e mais ao norte no final do mês. A posição mensal foi próxima a $2,0^{\circ} \mathrm{N}$ o que significa $1,0^{\circ}$ ao sul de sua posição média climatológica para este mês. Nesse mês, a maioria das linhas de cumulos-nimbos com formação na costa Atlântica apresentaram menos de 12 horas de duração. Em junho, a ZCIT oscilou entre $1,9^{\circ} \mathrm{N}$ e $6,9^{\circ} \mathrm{N}$ apresentando uma posição média mensal em $3,7 \mathrm{~N}$, aproximadamente $2,0^{\circ}$ ao sul de sua posição média climatológica. Nesse mês, mais de $50 \%$ das linhas de cumulos-nimbos com formação na costa Atlântica tiveram somente 6 horas de duração.

Nesse trimestre, na região de Belêm, a quantidade de chuva foi influenciada principalmente pelo retorno sazonal da ZCIT para o Hemisfério Norte e pela pouca duração da estrutura da banda de nebulosidade das linhas de cumulos-nimbos associadas à brisa maritima com formação na costa Atlântica.

o terceiro trimestre do ano de 1991, mostrou no Pacífico Tropical o início do desenvolvimento de um episódio ENOS, classificado como moderado ou fraco. No entanto, ao longo da costa oeste da América do sul a ATPS apresentou valores abaixo de $1,0^{\circ} \mathrm{C}$, que foram: $0,9^{\circ} \mathrm{C}$ no mês de julho, 
$0,3^{\circ} \mathrm{C}$ em agosto e em setembro.

Em Belém, verificou-se que os meses desse trimestre evidenciaram-se por apresentar uma quantidade de chuva bastante abaixo da média climatológica. O mês de julho apresentou um registro mensal de $29,3 \mathrm{~mm}$ e setembro um total de $28,1 \mathrm{~mm}$. Tais valores foram os menores registros, para os devidos meses, desde o ano de 1896. O valor de ICB foi $-4,4$ em julho, $-1,2$ em agosto, e $-3,2$ em setembro. O número de dias de ocorrências de chuvas foi de 11 dias em julho, 12 dias em agosto e 15 dias em setembro.

Nesse trimestre, a ZCIT não influenciou na quantidade de chuva na região de Belém. Em julho, a zCIT oscilou entre $3,9^{\circ} \mathrm{N}$ e $8,6^{\circ} \mathrm{N}$, com uma posição média climatológica em torno de $5,5^{\circ} \mathrm{N}$, que é aproximadamente $2,0^{\circ}$ ao sul de sua posição média climatológica para este mês. Nesse mês, de modo geral, o deslocamento das Iinhas de cumulos-nimbos associadas à brisa marítima com formação na costa Atlântica não foi significativo, ou seja, todas se deslocaram em média $2,0^{\circ}$ a $3,0^{\circ}$ de longitude oeste. Em agosto, a posição média climatológica da $\mathrm{ZCIT}$ foi de $6,9^{\circ} \mathrm{N}$, que é aproximadamente $1,0^{\circ} \mathrm{S}$ de sua posição média climatológica. Nesse mês, as linhas de cumulos-nimbos associadas à brisa marítima com formação na costa Atlântica apresentaram pouco desenvolvimento sobre a região. Em setembro, a posição média climatológica da ZCIT foi de $8,4^{\circ} \mathrm{N}$, que é aproximadamente $1,0^{\circ}$ ao norte de sua posição média climatológica. Esse fato mostrou que, pela primeira 
vez nos últimos 16 meses, a ZCIT encontrou-se em média ao norte de sua posição climatológica. Nesse mês, verificou-se que o campo de anomalias de temperatura da superficie do mar no Atlântico Tropical, apresentou anomalias negativas em torno de $-1,0^{\circ} \mathrm{C}$ próximo a Foz do Rio Amazonas.

Nesse trimestre, a escassez de chuva na Região de Belém foi causada pela inibição na formação de efeitos locais, fato esse característico nos anos de episódio ENos. outro fato que contribuiu para essa escassez de chuva foi uma diminuição da intensidade no dipolo de anomalias de temperatura de superficie do mar no oceano Atlântico (valores negativos no Atlântico Norte e positivos no Atlântico sul).

No quarto trimestre do ano de 1991, observou-se que no Oceano Pacífico Tropical as anomalias de temperatura da superficie do mar persistiram acima da média, em torno de $1,0^{\circ} \mathrm{C}$, com exceção da costa oeste da América do sul. Nesse trimestre, o episódio de ENos, classificado como fraco moderado, continuou o seu desenvolvimento atingindo sua fase madura no mês de dezembro. Na região do Niño $1+2$ a ATPS apresentou valores de $0,4^{\circ} \mathrm{C}$ em outubro e novembro e $0,7^{\circ} \mathrm{C}$ em dezembro.

Em Belém, verificou-se que esse trimestre a quantidade de chuva apresentou valores acima da média climatológica no mês de outubro e abaixo da média climatológica nos meses de novembro e dezembro. Os valores de ICB foram de 0,4 em outubro, $-1,5$ em novembro e $-0,8$ em 
dezembro. O número de dias de ocorrência de chuva foi de 22 dias em outubro, 8 dias em novembro e 15 dias em dezembro. Em outubro, a ZCIT apresentou uma posição média mensal em torno de $9,2^{\circ} \mathrm{N}$, o que é aproximadamente $1,4^{\circ}$ ao norte de sua média climatológica para este mês. Em novembro, a ZCIT começou seu deslocamento em direção ao Hemisfério sul. Entretanto, a sua posição média foi de $7,7 \%$, o que é aproximadamente $1,3^{\circ}$ ao norte de sua média climatológica para este mês. Nesse mês, a atividade convectiva na região de Belém apresentou-se muito pequena, ficando abaixo da média climatológica. Observou-se, também, que as linhas de cumulos-nimbos associada à brisa maritima com formação na costa Atlântica formaram-se ao norte do Equador, geralmente apresentando deslocamento insignificante, não havendo portanto associação com as chuvas da região. Em dezembro, a ZCIT continuou seu deslocamento para o Hemisfério Sul, oscilando entre $3,8^{\circ} \mathrm{N}$ e $6,4^{\circ} \mathrm{N}$, com uma posição média climatológica em torno de $5,2 \mathrm{~N}$, o que é aproximadamente $0,5^{\circ}$ ao norte de sua posição média climatológica para este mês. observou-se, contudo, que a ZCIT não esteve muito intensa na maior parte do mês. Esta diminuição da intensidade ocorreu em consequência da subsidência no oceano Atlântico provocada pelo episódio ENOS. Nesse mês, observou-se que as Iinhas de cumulos-nimbos associada à brisa marítima com formação na costa Atlântica apresentaram-se em quantidade abaixo do esperado. Esta característica anômala está relacionada com - efeito da circulação sinótica sobre a circulação de brisa 
marítima, sendo uma consequência direta do episódio ENos. No estudo da correlação entre ATPS e ICB, realizado no período de janeiro de 1987 a dezembro de 1991, verificou-se uma tendência de decréscimo da quantidade de chuva em Belém com o aumento de temperatura da superfície do mar da região do Niño $1+2$ do Pacífico Sul, conforme mostra a figura 43. Contudo, não se pode considerar esta correlação como um fator determinante na variabilidade de chuva da região de Belém, mas como ficou mostrado nesse estudo, outros fatores associados ao estado da atmosfera e dos oceanos, além do episódio ENOS, também podem afetar a quantidade de chuva na região. Observou-se que no primeiro trimestre, janeiro a março, período em que a ZCIT atinge as baixas latitudes somente em dois dos cinco anos estudados ocorreu coincidência na correlação. Tal fato foi observado no trimestre mais chuvoso do ano de 1992, quando os meses de janeiro e fevereiro apresentaram valores de chuva acima da média climatológica, março apresentou valores de chuvas próximos da média climatológica e as anomalias de temperatura da superfície do mar na região do Niño $1+2$ do Pacífico Sul foram positivas. No entanto, para comprovação de tal afirmação, sugere-se uma análise de um período mais longo, tendo em vista que a maioria dos anos analisados não foram característicos de episódios ENOS com intensidade forte. 


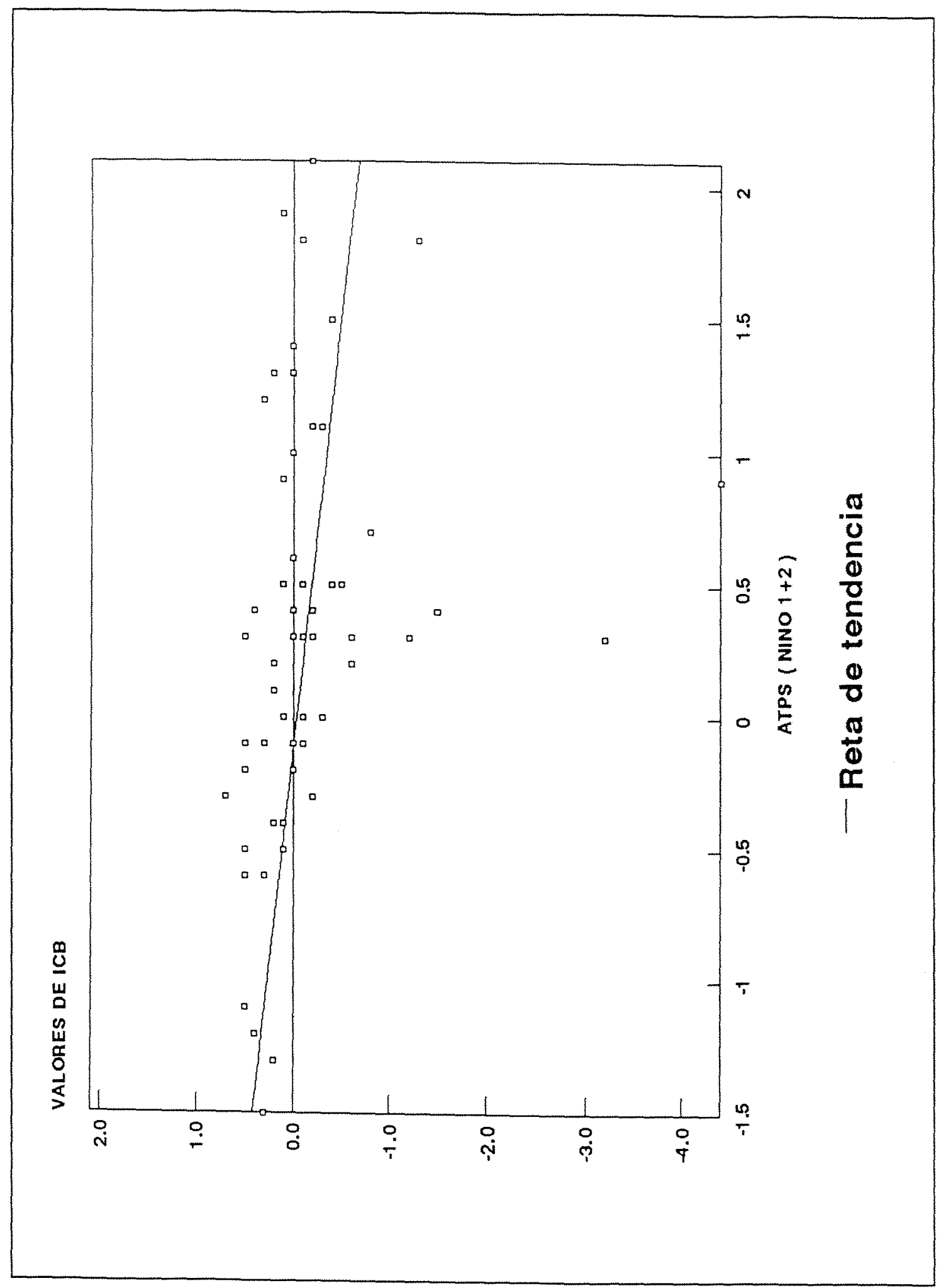

Figura 43 - Variação entre ATPS (Niño I+2) e ICB, período: $(1987$ - 1991). Fontes de dados:

1) ATPS (Niño 1+2) - CLIMANÁLISE

2) ICB - INMET 


\section{5 - CONCLUSÃO}

Como resultado desse estudo pode-se concluir que:

1) - A regiāo de Belém nos últimos 95 anos, apresentou uma tendência crescente na quantidade total anual de chuva, corresponde ao valor de $458,5 \mathrm{~mm}$. No entanto, uma tendência menos evidente de quantidade de chuva mensal foi constatada nos meses de junho e julho.

2) - Nenhum fator determinante esta influenciando no comportamento das temperaturas extremas na região de Belém. A análise de tendência dos últimos 95 anos, mostrou que as temperaturas extremas sofreram pequenas variações, com exceção da temperatura máxima absoluta que apresentou, no começo do século (1896-1930), uma elevação na tendência com valores superiores a $1,0^{\circ} \mathrm{C}$.

3) - A quantidade de chuva na região de Belém, sofre um decrescimo em anos de evento El Niño - oscilação Sul (ENOS). No entanto, o episódio ENOS parece não ser um fator determinante no comportamento das chuvas da região, pois além desse episódio, a temperatura da superfície do mar no oceano Atlântico influencia diretamente na quantidade de chuva, principalmente nos meses de janeiro, fevereiro e 
março, considerando o trimestre mais chuvoso da região, época em que a zona de convergência Intertropical (ZCIT) oscila na faixa equatorial. 


\section{REFERENCIAS BIBLIOGRÁFICAS}

ALVES, J.M.B. \& REPELLI, C.A. Estudo preliminar entre chuvas no setor norte do nordeste e os eventos El Niño Oscilação sul (ENOS). In: CONGRESSO BRASILEIRO DE METEOROLOGIA, 7., São Paulo, 1992. Anais. São Paulo, SBM, 1992. p. $72-6$.

ARANTES, J.T. El Niño, quando o tempo enlouquece. Revista os Caminhos da Terra, São Paulo, 1(5): 67-70, set. 1992 .

BASTOS, T.X. Delineating agroclimatic zones for deforested areas in Pará state, Brazil. Hawaii, 1990. 170p. (Doctor - University of Hawaii).

BASTOS, T.X. \& DINIZ, T.D. de A.S. Disponibilidade de energia eólica no litoral Amazônico. In: CONGREsso BRASILEIRO DE AGROMETEOROLOGIA, 4. , Londrina, 1985. Resumos. Campinas, Fundação Cargill, 1985. p. 142. 
BASTOS, T.X.; ROCHA, E.J.P. da; ROLIM, P.A.M.L; DINIZ, T.D. DE A.S.; SANTOS, E.C.R. dos; NOBRE, R.A.A.; CUTRIN, E.M.C.; MENDONÇA, R.L.D. de. O estado atual dos conhecimentos de clima da Amazônia brasileira com finalidade agrícola. In: SIMPÓsIo DO TRÓPICO ÚMIDo, 1., Belém, 1984. Anais. Belém, EMBRAPA/CPATU, 1986. p.19-36.

BASTOS, T.X.; FILHO, H.C.; DINIZ, T.D. de A.S.; LOBATO, V.H. de B. Flutuação das chuvas na regiāo de Belém em distintos intervalos de tempo. Período 1967-1983. In: SIMPÓSIO DO TRÓPICO ÚMIDO, 1., Belém, 1984. Anais. Belém, EMBRAPA/CPATU, 1986. p. 37-43.

COHEN, J.C.P. Um estudo observacional de linhas de instabilidade na Amazônia. São José dos Campos, 1989. 153p. (Mestrado - Instituto de Pesquisas Espaciais).

COHEN, J.C.P.; DIAS, M.A.F.S.; NOBRE, C.A. Aspectos climatológicos das linhas de instabilidade na Amazônia. Climanálise, São José dos Campos, 4(11):34-40, nov. 1989.

CostA, A.C.L. da; OLIVEIRA, M. do C.F. dE; COSTA, J. de P. R. da; PINHEIRO, J.C.R. Distribuição média diária de unidades térmicas no Estado de Pará. IN: CongREsso BRASILEIRO DE METEOROLOGIA, 6., Salvador, 1990. Anais. Salvador, SBM, 1990. p. 74-8. 
CUNHA, O.R. da \& BAstos, T.X. A contribuição do Museu Emílio Goeldi à meteorologia na Amazônia. Belém, Museu Paraense Emílio Goeldi, 1973. 69 p. (Museu Paraense Emílio Goeldi. Publicação Avulsa, 23).

CUTRIN, E.M.C. \& COHEN, J.C.P. Estudo dos sistemas atmosféricos produtores de chuvas no leste paraense. In: CONGRESSO BRASILEIRO DE AGROMETEOROLOGIA, 5., Belém, 1987. Coletânea de trabalhos. Belém, SBA, 1987, p. 260.

FALESI, I.C. Fatores climáticos e a fertilidade de solos tropicais. Belém, SAGRI, 1982. 37p.

FILHO, H.C.; BASTOS, T.X.; DINIZ, T. D. de A.S. Estimativa de precipitação para diferentes níveis de probabilidade em quatro períodos de tempo segundo a distribuição gama Belém, pará. In: SIMPósio Do TRópICo ÚMIDO, 1., Belém, 1984. Anais. Belém, EMBRAPA-CPATU, 1986. p. 44-50.

GALATE, R, dos $S$. Estudo das precipitações pluviais no munícipio de Belém-PA, através da distribuição gama. Piracicaba, 1987. 70p. (Mestrado - Escola Superior de Agricultura "Luiz de Queiroz"/USP) . 
GARNETT, E.R. \& KHANDEKAR, M.L. The impact of large-scale atmospheric circulations and anomalies on Indian monsoon droughts and floods and in world grain yields - a statistical analysis. Agricultural and Forest Meteorology, Amsterdam, 61: 113-28, 1992.

HANDLER, P. Corn yields in the United states and sea surface temperature anomalies in the Equatorial Pacific ocean during the period 1868-1982. Agricultural and Forest Meteorology, Amsterdam, 31: 25-31, 1984.

KOUSKY, V.E. \& KAGANO, M.T. A climatological study of the tropospheric circulation over the Amazon Region. Acta Amazônia, Manaus, 11(4): 743-58, 1981.

MARCUS, K.G. El Niño, its impact on 1992 world sugar production. Sugar y Azucar, New Jersey, 87(4): 23-8, 1992 .

MARQUES, J. Contribuição ao estudo hidrológico da bacia Amazônia. Piracicaba, 1976. 118p. (Mestrado - Escola Superior de Agricultura "Luiz de Queiroz"/USP).

MARQUES, J.; SANTOS, J.M. dos; SALATI, E. Considerações sobre os ventos na região Amazônica. Acta Amazônica, Manaus, 8(1): 110-3, 1978 . 
MARQUES, J.; SANTOS, J.M. dos, SALATI, E. O armazenamento atmosférico de vapor d'água sobre a regiāo Amazônica. Acta Amazônica, Manaus, 9(4): 715-21, 1979.

MARQUES, J.; SANTOS, J.M. dos; SALATI E. O campo do fluxo de vapor d'água atmosférico sobre a região Amazônica. Actà Amazônica, Manaus, 9(4): 701-13, 1979.

MARTORANO, L.G.; PEREIRA, L.C. , COSTA, A.C.L.; RIBEIRO, J.T. variabilidade da precipitação pluviométrica em Belém Pará associada ao fenômeno "El Niño". In: CONGRESSO BRASILEIRO DE METEOROLOGIA, 7., São Paulo, 1992. Anais. São Paulo, SBM, 1992. p. 86-9.

MOLION, L.C.B. Climatologia Dinâmica da Região Amazônica: mecanismo de precipitação. Revista Brasileira de Meteorologia, são Jose dos Campos, 2(1/2): 107-17, jun./ dez. 1987 .

MOLION, L.C.B. \& KOUSKY, V.E. Climatologia da dinâmica da troposfera tropical sobre a Amazônia. São José dos Campos, INPE. 1985. (INPE - 3560 - RPE/480).

MOLION, L.C.B. \& KOUSKY, V.E. Climatologia da dinâmica da troposfera sobre a Amazônia. In: SIMPósIo DO TRóPICO ÚMIDO, 1. Belém, 1984. Anais. Belém, EMBRAPA/CPATU, 1986. p. 87-96. 
NECHET, D. Variabilidade diurna da precipitação em Belém PA. In: CONGRESSO BRASILEIRO DE METEOROLOGIA, 3., Belo Horizonte, 1984. Anais. Rio de Janeiro, SBM, 1984. p. $204-11$

NEVES, E.K.; LAZINSKI, L.R.; SALES, N.D. de; COSTA. M.C.G.; ARAUJO, M.I.M. de; ALMEIDA, R.M.B. de. Informações agrometeorológicas de trópico úmido brasileiro e meio ambiente. Brasilia, Divisāo de Estudos e Aplicações do Instituto Nacional de Meteorologia, 1989. 123p. (No prelo)

NIMER, E. Climatologia da Região Norte: Introdução à climatologia dinâmica. Revista Brasileira de Geografia, Rio de Janeiro, 34(3): 124-53, 1972 .

PENTEADO, A.R. Bélem, estudo de geografia urbana. Belém, Coleção Amazônia, 1971. 1 v. (Série José Veríssimo) .

RAO, V.B. \& HADA, K. Characteristics of Rainfall over Brazil: Anual Variations and Connections with the Sourthern Oscillation. Theoretical and Applied Climatology, Vienna, (42):81-91, 1990. 
RIBEIRO, A. Análise das variaçōes climáticas observadas na região de Manaus (AM). Piracicaba, 1991. 113p. (Mestrado - Escola Superior de Agricultura "Luiz de Queiroz"/USP).

RIEHL, H. Tropical Meteorology. New York, McGraw Hill, 1954. $322 \mathrm{p}$.

SALATI, E.; RIBEIRO, M.N.G. Floresta e clima. Acta Amazônica, Manaus, 9(4): 15-22, 1979.

SANSIOGOLO, C.A.; RODRIGUES, R. de C.M.; ETCHICHURY, P.C. Tendências nas temperaturas médias do Brasil. Climanálise, São José dos Campos, 5(9): 33-41, set. 1990.

SANTOS, O.C. de O. Distribuição espacial e temporal de unidade térmica estimadas para região Amazônica. In: CONGRESSO BRASILEIRO DE AGROMETEOROLOGIA, 7., Viçosa, 1991. Resumos. Viçosa, UFV/Impr. Univ., 1991. p.130-2.

SUPERINTÊNDENCIA DE DESENVOLVIMENTO DA AMAZÔNIA. Projeto de Hidrologia e Climatologia da Amazônia. Atlas climatológico da Amazônia. Belém, 1984. 125p. (Publicação, 39). 
UVO, C.R.B. \& NOBRE, C.A. A zona de convergência intertropical (ZCIT) e a precipitação no norte do Nordeste do Brasil. Parte I: a posição da ZCIT no Atlântico Equatorial. Climanálise, são José dos Campos, $4(7): 34-4, j u 1 ., 1989$. 